


Digitized by the Internet Archive in 2007 with funding from Microsoft Corporation 
OUR ASIATIC NEIGHBOURS

Indian Life, By Herbert Compton Japanese Life, By George W. Knox Chinese Life, By E. Bard Philippine Life, By James A, Le Roy

Australian Life, 
OUR ASIATIC NEIGHBOURS

\section{AUSTRALIAN LIFE IN TOWN AND COUNTRY}






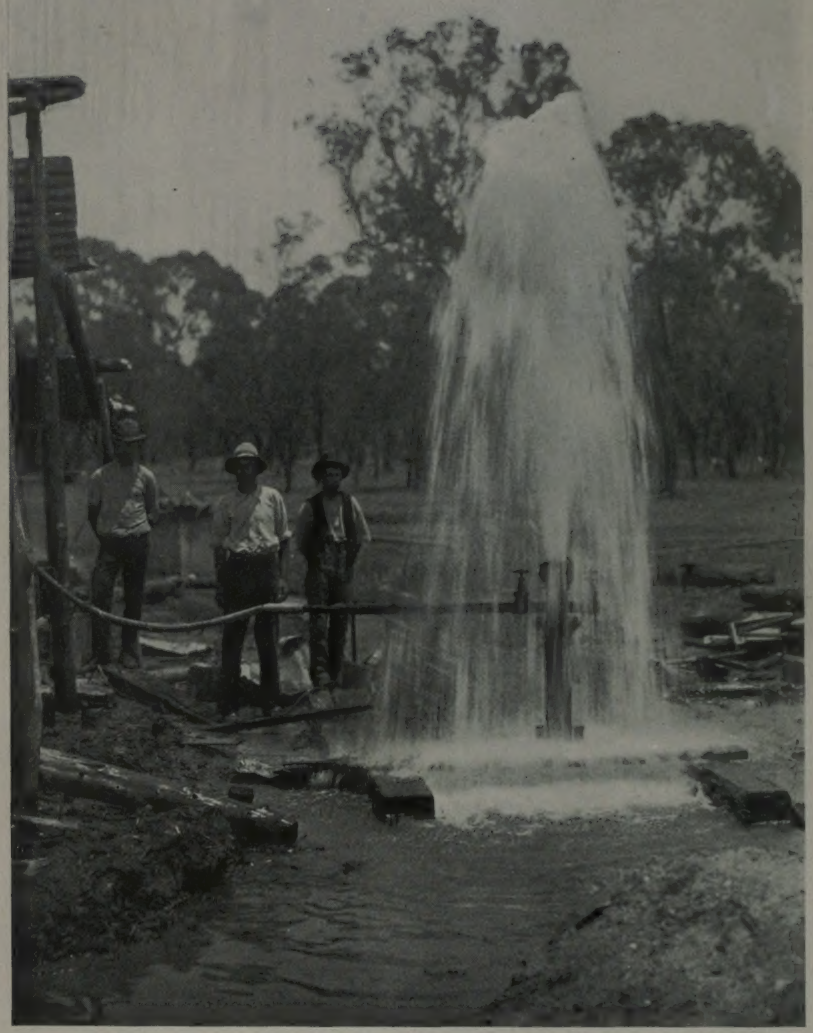

HYDRAULIC MINING, THE WALLON BORE, MOREE DISTRICT. DEPTH 3695 FEET, FLOW 800,000 GALS., TEMP. $114^{\circ} \mathrm{F}$. 
f : AUSTRALIAN

LIFE IN TOWN

AND COUNTRY

24 BY E. C. BULEY

ILLUSTRATED

G. P. PUTNAM'S SONS NEW YORK AND LONDON Tbe Tkntckerbocker Dress

1905 


\section{COPYRIGHT, I9O5}

BY

G. P. PUTNAM'S SONS

Cbe Wnickerbocker press, Hew Dork 


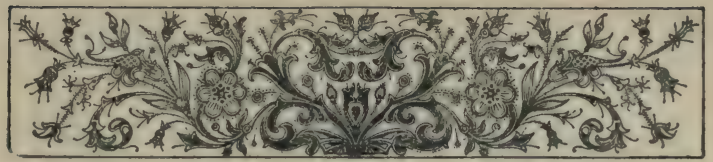

\section{CONTENTS}

CHAP'TER I

COUNTRy and Climate.

CHAPTER II

SQUATTERS AND STATIONS $\quad \cdot \quad \cdot \quad \cdot \quad \cdot \quad$ I 14

CHAPTER III

STATION WORK

CHAPTER IV

ON A SELECTION

CHAPTER V

THE NEVER-NEVER LAND • . • . . 55

CHAPTER VI

ON THE WALIABY Track • . . . 69

CHAPTER VII

IN TTME OF DROUgh'T $\mathrm{T}$. $\quad . \quad . \quad . \quad$. $8 \mathrm{I}$ 
CHAPTER IX

LIFE IN THE CITIES . . . . . . 108

\section{CHAPTER $\mathbf{X}$}

STATE SOCIALISM AND THE LABOUR PARTY - I22

\section{CHAPTER XI}

GOLDEN AUSTRALTA . . . . . . . I34

CHAPTER XII

FARM AND FACTORY

CHAPTER XIII

The AUSTRatidan Woman . . . . . I57

CHAPTER XIV

HOME AND SOCIAI, LIFE .

CHAPTER XV

The Australian at Play . . . . . 182

CHAPTER XVI

THE ABORIGINES

CHAPTER XVII

A WhITE AUSTRALIA . . . . . . 208 


\section{Contents}

CHAPTER XVIII

EDUCATION, LITERATURE, AND ART

220

\section{CHAPTER XIX}

NATYONAL LIFE IN AUSTRALIA

- 232

CHAPTER XX

THE AUStralian * . . • . . * 245

CHAPTER XXI

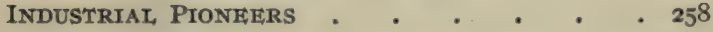

CHAPTER XXII

AUSTRALIA'S Destiny . . . . . . 270

INDEX $\quad \cdot \quad \cdot \quad \cdot \quad \cdot \quad \cdot \quad 283$ 



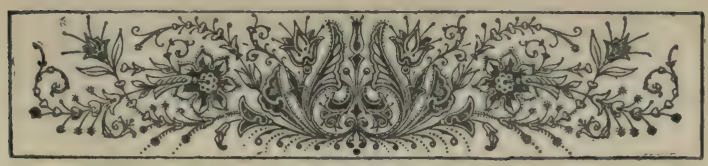

\section{ILLUSTRATTIONS}

PAGE

Hydraulic MINING, THE, WALLON BORE, MOREE DISTRICT. DEPTH 3695 FEET, FLOW 800,000 GALs., TEMP. II $4^{\circ} \mathrm{F}$. . . . Frontispiece

HeAd OF Freshwater RIVER, NationaI, PaRk i6

MOUNT Victoria Pass, NEW SOUTH Wales . 28

(Courtesy of Marselis C. Parsons, Essq., New York.)

STATE NURSERY NEAR CAIRNS • . . 46

A MineR's HuT, LiThgow VALI,EY, NEW SOUTH WALES

Brokein Hil, Sil, ver MiNes, New SOUTh WALES

ROAD SCENE ON THE CAMBERWARRA MOUNTAIN, SHOALHAVEN DISTRICT . . . . . 86

(Courtesy of Marselis C. Parsons, Essq., New York.)

SLUTCING FOR GOLD AT FRESHWATER . . . IO4

Cattite Crossing, Nepean Towers, New South WALES . . . . . . . . I2O

(Courtesy of Marselis C. Parsous, Essq., Nèw York.)

HANNAN STREET, LOOKING WeST, KALGOORLIC, IN 1895 . 
HANNAN STREET, KALGOORLIC, IN I905 . . P44

VIEW OF A QUEENSLAND SEAPORT TOWN, TOWNSVILLE . . . . . . . . I56

Planting Sugar-Cane, QUeENSLAND . . . I70

AT WORK AMONGST THE CANE . . . . 182

VIEW OF HARTLEY VALE • • • • . 202 (Courtesy of Marselis C. Parsons, Eksq., New York.)

SCENE, AT A WAYSIDE INN, NEW SOUTH WALES 224

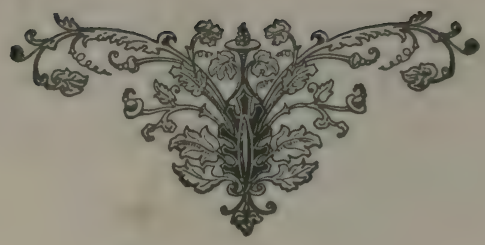


AUSTRALIAN LIFE IN TOWN AND COUNTRY 



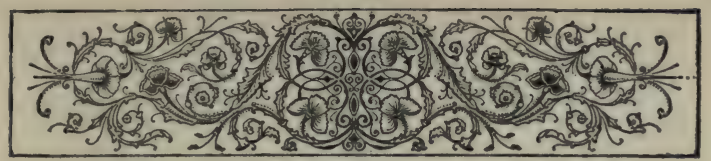

\title{
AUSTRALIAN LIFE
}

IN TOWN AND COUNTRY

\author{
CHAPTER I \\ COUNTRY AND CLIMATE
}

T has often been claimed for the British that they are a successful colonising people, and this claim has not been advanced without very sufficient grounds. Those who assign this characteristic to the race imply that it possesses, above all things, the faculty of adaptability. If the colonising Briton were not able to suit himself readily to the necessities and the climatic conditions of his new environment, he would not be a success as a colonist. It is further characteristic of the Briton that, until very recently, he has not been disposed to exhibit any satisfaction in his colonising feats. His attitude in the past has been that of a father of a family of young children, who regards each new arrival as a source of additional expense and responsibility. 
In the last quarter of the nineteenth century, however, a new era was inaugurated, when the importance of the many colonies Great Britain has planted in America, Africa, and Australasia was at last recognised. The problems of colonial life are now engaging the attention of the most thoughtful of British statesmen and public officials, and the study of colonial affairs has already shown that in each of the great British colonies different circumstances are producing an entirely separate type of over-sea Briton.

It is well that this fact should be recognised, if the fabric of Empire now being created is ever to be made complete. In a new country, events move with a rapidity bewildering to those born and brought up under settled and accepted conditions. Ten years served to convert Australia from a collection of separate provinces into a nation. Not very long ago it was the custom to write of the Australian as an exiled Briton, who jealously maintained British customs and traditions in his new environment, and always spoke of the British Isles as "home." Observers who obtained their information concerning Australia during visits paid to the chief Australian cities, or while enjoying the delightful hospitality of some large and prosperous Australian station, were induced to regard this as an established state of affairs, rather than an interesting phase in the development of a new community. They lost sight of the fact that a native-born race was grow- 


\section{Country and Climate}

ing up, to whom many of the British customs would be traditions instead of things remembered with sentimental pleasure, and that to the succeeding generation even the traditions would be lost.

For instance, the Englishman born celebrated Christmas Day in Australia in the good old-fashioned style, with a smoking hot joint, and an abundance of rich puddings and pies. His Australian-born son in many cases maintained the custom, although fully alive to the absurdity of such fare at a season when the thermometer stands at more than one hundred in the shade. The present-day Australian may often be found spending his Christmas Day in some shady fern-tree gully, clad in the easiest of clothes, and with everything as cool as it is possible to be made. The Australian climate renders the English Christmas festivities practically impossible. In the same way many other customs carried from Great Britain to Australia by the pioneers of the new race have been modified by conditions against which the first-comers struggled, but which their grandchildren accept as part of their everyday life.

For this reason, any one seeking to make acquaintance with the Australian life of the present day must bear in mind that it has essentially changed during the past twenty years, and that in another quarter of a century it will probably have advanced yet another stage in its evolution. The chief factors conducing to this evolution are 
the nature of the Australian continent itself, its isolation in the Southern seas, its climate, and the peculiar conditions under which it was colonised.

It is necessary to conceive of Australia not as a colony containing a population equal to little more than one half the number of inhabitants of the city of London, but as an immense continent, three million square miles in extent. Compared to other continents, which have their coast lines indented by huge gulfs, and which push great peninsulas out into the ocean, Australia is a singularly solid piece of land. As a matter of fact, its coast line is smaller in proportion to its area than that of any other continent. The physical contour of the continent is remarkable for the same monotony. Its surface is, broadly speaking, a graduated system of immense plateaux and plains. The one striking feature in Australian orography is a strip of highland running from north to south along the eastern coast. These highlands, which separate the coastal plains and valleys from the immense level interior of the continent, bear the general name of the Dividing Range. In the south-eastern corner of Australia, this range bends westward, traversing the whole state of Victoria and ending near the eastern border of South Australia. It is in the south-eastern corner that the Dividing Range attains its greatest altitude, several peaks of the Australian Alps being over seven thousand feet in height.

The eastern portion of Australia consists, then, 


\section{Country and Climate}

first, of a coastal strip, backed by a mountain range, beyond which a plateau gradually declines to the low-lying central plains. The western division of Australia, a large part of which is still practically unknown country, may also be described as a low plateau, broken here and there by well-marked mountain ranges of no great height.

Considerable prominence has been given to the position and character of the Dividing Range, because of its influence upon the climate of Australia. The chief rain-bearing winds, blowing from the eastward and meeting these highlands, provide the coastal districts with a plentiful rainfall. Beyond them the rainfall is scanty and irregular, growing less in proportion to the distance from the eastern coast. Hence the interior of Australia suffers from dryness. The average rainfall of more than half the continent is less than twenty inches a year, and for the greater part of this area an annual rainfall of ten inches and under is customary in ordinary seasons. As the evaporation caused by the sun's heat is very great in Central Australia, it is obvious that the normal condition of the soil there must be one of extreme aridity.

The Dividing Range is naturally the main watershed of the continent. The rivers flowing to the eastern coast are necessarily short, but some of them are of considerable volume and depth. Of those flowing westward, the most important is the Murray, which enters the sea through a large shallow lake in South Australia. This river, with 
its tributaries, the Darling and the Murrumbidgee, forms the most considerable waterway of Australia, opening up part of the interior to river vessels of shallow draught. Other rivers flowing westward, such as the Diamantina and the Barcoo, lose themselves in the sands of Central Australia, or trickle into the salt lakes of the interior. In the dry season, they can hardly be termed rivers, being rather a series of water-holes, connected by a dry stream-bed. But when fed by the tropical rains of a wet season, these rivers discharge immense volumes of water, sometimes overflowing their banks and flooding large tracts of country.

When the contrast between coastal Australia and the interior is considered, - the one district well watered and possessing rivers navigable, although short, while the other is arid and flat, and lacks rivers communicating with the sea,-it is not surprising to find that the population remains in the coastal districts. There are less than four million people in the whole continent, and more than four-fifths of them reside within a hundred miles of the coast. The centres of settlement, dotted around the coast, are necessarily far apart, for as the country was settled, it was split into a number of states for the purpose of government. Each of these states-until the Federation, which began with the present century-was concerned solely with its own affairs, and in each of them there grew up one centre of population and trade. 


\section{Country and Climate}

These state capitals are all seaport towns, and irom them have been constructed railways, extending throughout the coastal districts, and in some cases far into the interior. The coastal districts are largely agricultural, and contain smaller towns which are farming centres. The interiorthe "back country," as it is sometimes called-is given up to grazing. The grazing areas, called "runs" in Australia, vary in size, some of those in the more remote districts equalling the extent of one of the smaller English counties.

The Australian, it will be seen, dwells either in the large state capital, which acts as the sole trade outlet and inlet to the whole state ; or in the agricultural districts immediately behind the coast ; or in the back country, given up to grazing. The Australian of the cities speaks of the rest of his continent as "the bush." The dwellers in the agricultural country speak of the district further inland as the "back country." Those themselves in the back country have behind them a land, partly unknown, and therefore attractive to the adventurous, which they call the "Never-Never Land."

It has often been declared that the distinctive characteristic of the bush is its monotony. Flat or gently undulating land, dotted with trees nearly all belonging to the same family, and presenting a uniform dark green hue to the eye, extends for hundreds of miles. The trees are not so close together as to prevent the grass from 
flourishing on the plain beneath them, and there is little or no undergrowth. The best of this country has been not inaptly compared to the park land of one of the flatter English counties.

This is a common aspect of the bush, but it is only one aspect, and the bush has many. There are Australians to whom the word recalls the picture of a roaring mountain stream of cold, clear water. The banks are carpeted knee-deep with maiden-hair and coral fern, and out of this tender green rise the velvety brown boles of the tree ferns, each crowned with its wide circle of broad fronds. Above the tree ferns trembles the graceful feathery foliage of the sassafras, and higher than the sassafras grows the myrtle, most shapely of all Australian trees. From this tangle of forest and fern, the tall mountain ashes rear their smooth grey columns, one hundred and fifty feet of straight timber before the first branch. The air is sweet with the scent of fragrant meadow plants, and from the thicket close at hand there comes the long-drawn note of the whip bird, with its curious and startling staccato ending. Somewhere in the distance the lyre bird is imitating all the sounds of the forest, now fluting like a magpie, and anon warbling like a whole chorus of wrens. This is the bush in one of its most gracious aspects.

Fifty miles nearer the coast, the mountain stream has become a brimming river, winding through fertile valleys and broad sunlit plains. Its banks 


\section{Country and Climate}

are lined with groves of pleasant wattles, that are covered in the early spring with a garment of yellow blossoms, so fragrant that the warm breezes carry their message to the distant city, and men there know that winter has now become spring again. Between the river and the distant blue hills, the grassy meadows are unbroken by any tree, save the clumps of lightwoods, with thick and shining foliage. These cast across the grass a welcome shadow, in which the sheep and cattle cluster as the sun grows warm. From the distance, blue hills beckon invitingly, but viewed close at hand, they are forbidding and desolate. The soil is hard and stony, and nourishes only a coarse, scanty grass, with a few bristling thorny shrubs here and there. The trees are twisted and stunted, and their trunks are clad in a rough, coarse bark that hangs from them in long untidy strips. There is no pleasant stream to be found here: one walks for miles only to find the ground growing harder and stonier, and the undergrowth scantier and less attractive. A bush fire swept down this range the summer before last, as the bare branches of the trees and their blackened trunks bear witness. Near the trunks there is a fringe of fresh green foliage, out of which the skeleton branches protrude most uncompromisingly. It is not cheerful or inviting, but the bush holds scenes that are sterner still.

There are wastes of sand hummocks, with crest and hollow as regular as the wave and trough of 
the ocean. Over all these wastes grows nothing but the stiff spinifex grass, recognised as an unfailing sign of barren land. That country is dreary and monotonous beyond conception, but not so chilling as the mysterious dead forests, where the trees have long ago parted with every sign of leaf or bark, and stand with white, palsied trunks and gnarled limbs writhing into all fantastic imagery. In the daytime, they are gaunt and forbidding, but seen in the white light of an Australian moon, when the wailing cry of the curlew is never silent, they fill the soul with a profound melancholy.

The broad Western plains are more cheerful, with their clumps of drooping myalls, that glisten like silver when the wind stirs their leaves. The grey salt bush that covers the plain is not attractive to the eye, but it has the merit of being useful. There are other plains, where neither tree, bush, nor herb covers the nakedness of the red soil, and where the wind comes heralded by a cloud of dust that settles on everything, choking the dry creek-beds, drifting over fences and even buildings, and smothering the whole world with its effacing redness. To the Australian, it is all the bush. The mangrove swamps and dense tropical forests of the North, the tracts of giant timber in South-western Australia, the "scrub" wastes of the interior where nothing can live, all go to make up the bush.

The occupation of the interior began early in the nineteenth century, with the arrival of the 


\section{Country and Climate}

free settlers. Convict stations had been established on the coast, and free men had only been too glad to escape the convict taint by pushing across the Dividing Range, where the early explorers had found passes through the hills to the good land beyond. The wisdom of Captain Macarthur, who provided the new country with a breed of sheep bearing the finest wool, was justified by the reputation gained by Australian merino wool in the markets of the Motherland. There was plenty of room for all while the foundations of the great pastoral industry, Australia's sole resource until the middle of the nineteenth century, were being laid. Then came the discovery of the gold, which attracted throngs of enterprising and adventurous men to Australia. In those stirring times, the coastal cities began to expand: their harbours were full of shipping, and their streets were crowded with newcomers. These spread over the face of the land, passing from one newly discovered goldfield to another, everywhere forming fresh settlements. When the gold fever abated, many of them reverted to their original occupations, while others obtained grants of land from the Government, and occupied themselves with farming and pastoral pursuits.

Thus Australia obtained population, but with the decline of the goldfields came the discovery that farming did not pay. The farmers suffered from the want of a large local market, and from the isolated position of Australia, which at that 
time rendered the export of farm produce of a perishable nature almost an impossibility. The pastoralist, with his wide expanses of grazing land and inexpensive methods, could pay freights to the Old World on his wool and tallow and still flourish. It was not so with the agriculturist, who found the markets glutted with the perishable products of his farm, while wheat-growing Russia and America possessed advantages of po. sition which left him unable to compete with them. In these circumstances, some of the Australian States initiated a policy of protective tariffs, designed to hasten that stage of national development when the manufacture of the raw products of the country should be localised. The immediate result of this policy was a further accession of population to the capital cities, where the new factories were established.

The last phase in Australian development is the result of the improvement which has taken place in the arrangement for the transport of perishable goods in a refrigerated condition. The cold chamber and the cold-storage depot have turned the thoughts of Australians to dairying, fruit growing, and poultry farming, and have created a new demand for agricultural land.

It is my task to sketch the conditions of Australian life at this stage in the history of the continent. I have aready indicated the size and importance of the Australian capital cities, from which the visitor to Australia gains the most last- 


\section{Country and Climate}

ing impression of the Antipodes. Those cities have been frequently described as British cities, planted in more genial climate and under more favourable circumstances. There are no essential differences between the mode of life of a citizen of Sydney and a citizen of Liverpool, although in many minor details interesting distinctions may be observed. But in the bush, a new type of Briton with distinctive faculties and characteristics has already been evolved. The men who live on the land are the typical Australians, and the courage and endurance with which they face the hardships and uncertainties of their life provide the brightest promise for the future of the new nation.

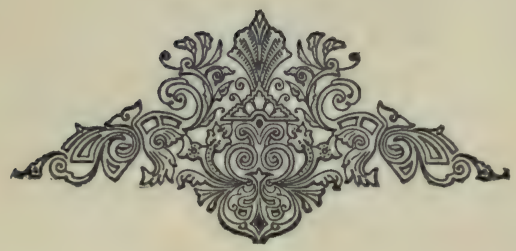




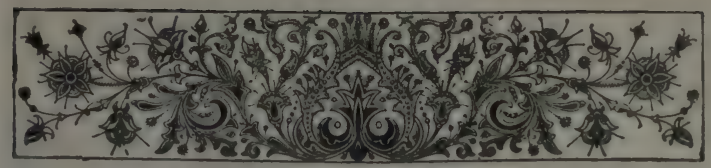

\section{CHAPTER II}

\section{SQUATTERS AND STATIONS}

THE men who laid the foundations of the pastoral industry were trespassers in the eyes of the law. They wanted the right to run their stock on large areas of land, transferring them from place to place as pasturage and water falled. They could not by any possibility purchase so much land as they required for this purpose, and the terms on which they could obtain leasehold rights were prohibitive. They therefore occupied the land without possessing any authority to do so, and thus obtained their name of "squatters." The importance to the new colony of the wool they produced preserved them from interference, and in time, their position was recognised by the introduction of a system dividing the back country into " pastoral districts," which might be occupied on the payment of a reasonable yearly rental. No fence marked the boundary of the early squatter's run. The fixing of such a limit was often a matter of arrangement with the nearest neighbour, distant a long day's ride on horseback. Just as often, the squatter was in 


\section{Squatters and Stations}

undisputed possession of a district more than large enough for his flocks and herds, which were transferred from one spot to another, wherever abundance of food or water might be found. Each flock was in charge of a shepherd, whose duty it was to keep the sheep within certain limits, and to guard the lambs from their worst enemy, the dingo, or wild dog. The shepherd lived the life of a hermit, probably seeing no human being except the man who brought him his stores of tea and flour from the head station at fixed periods, and relying for company upon his dogs. There was no talk of overstocking in those days. In bad seasons, the stock were moved to new pastures, hitherto untouched, and in good years they rioted in the superabundant pastures.

Prices for Australian wool ruled high, and the squatters prospered until the very mention of the word came to suggest the possession of wealth. Who has not heard of the wool "kings" of Australia? They had their town mansions standing in spacious grounds and occupying the most desirable situations in the best suburbs of Sydney and Melbourne. With princely disregard of cost, they erected dwellings on their runs, designed to afford their occupiers the maximum of comfort and to neutralise the more unpleasant conditions of the Australian climate. They kept racing studs, drove four-in-hand drags, and entertained chance visitors with a liberality so open-handed that Australian hospitality obtained a well-deserved 
reputation in the Old World. There is a true story told of a young squatter who, to provide for the comfort of his guests in hot weather, had two tons of ice packed in new blankets and despatched from Syduey. On its arrival at the railway terminus, the ice was transferred to a teamster's waggon, and a journey of two hundred miles under a hot sun so reduced its bulk that only a few small blocks reached their destination; yet with this return for his very expensive experiment, the squatter professed himself more than satisfied.

In time, the demand for pastoral holdings caused boundaries to be strictly defined, and runs had to be fenced. The increase of his flocks and the limitation of his runs caused the squatter to feel the pressure of those dry seasons when stock dies from want of food and water. The throwing open of the pastoral districts to the "selector" struck another blow at the prosperity of the squatter, as we shall presently see. Then came the plague of rabbits, devouring the grass, and leading to legislation which involved the pastoralist in heavy expense for rabbit extermination. Squatting was no longer a sure road to fortune, but a speculative undertaking, the squatter being dependent upon the uncertain rainfall and the fickle climate for his profits. Such is the position of some of the pastoralists at the present time. Many of the descendants of the squatting pioneers, it is true, have inherited holdings in 


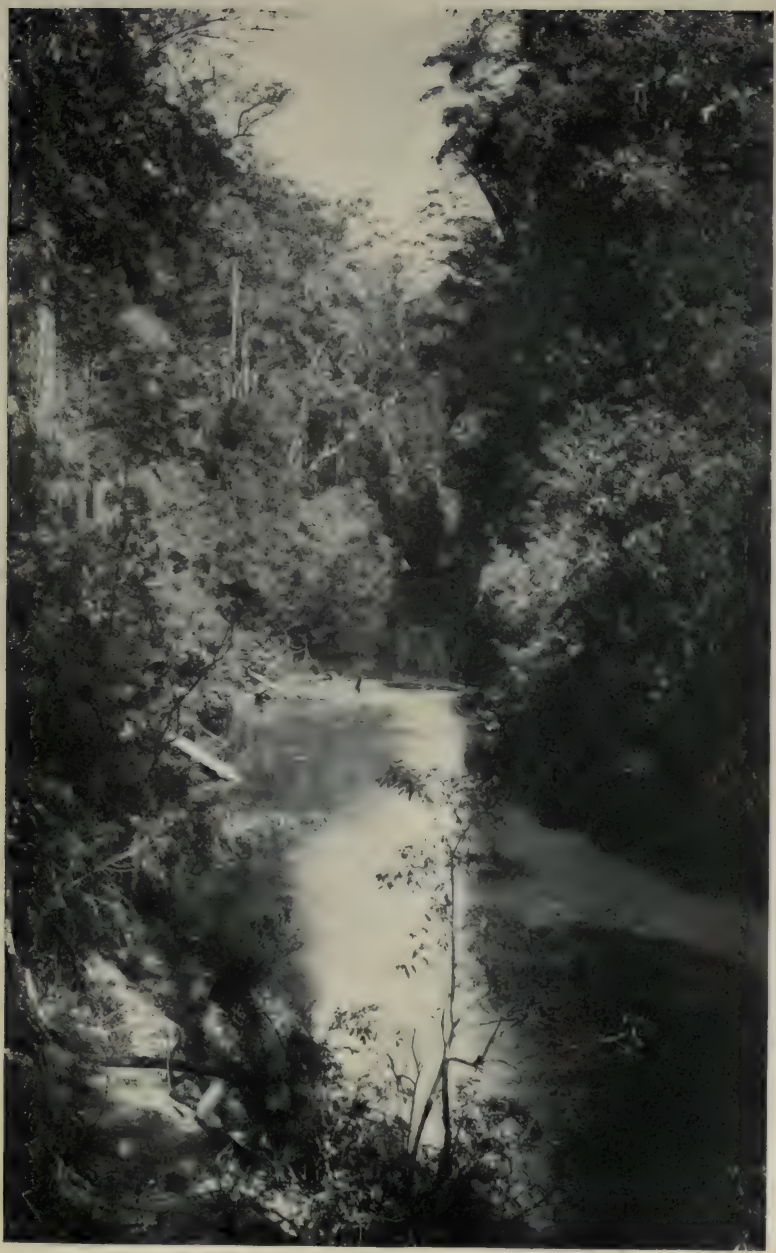

HEAD OF FRESHWATER RIVER, NATIONAL PARK. 



\section{Squatters and Stations}

favoured localities where the rainfall is regular and the pasturage abundant. Long experience has shown how these stations can be managed to the best advantage, and, in many cases, they yield their owners large incomes even in the worst seasons.

On one of these stations, pastoral life may be seen at its best, and I propose to describe a typical one, situated in the Riverina district of New South Wales. The "run" consists of a triangle of land enclosed by two streams, the confluence of which on their way to the river Darling forms the apex of a triangle. The third boundary, the base of the triangle, is a well-made public road. The run itself is fenced off from the road by a stout three-railed fence, and is divided into paddocks by similar fences, or lighter ones made of wire stretched through posts. A white gate on the boundary fence marks the drive leading from the public road through the run, and a similar gate at each subdivisional fence points its course to the homestead. The homestead itself is a substantial house of stone, built after the fashion of a bungalow, with only one story, and a broad veranda running around three sides of it. Grapevines and passion-flower shade the veranda, and the front of the house looks over a spacious garden and orchard, with a thick hedge of quince trees. On the veranda are easy-chairs and lounges, and a table strewn with the latest English magazines as well as the admirable weekly 
papers that are a feature of Australian journalism. The windows run down to the floor ; the doorway is wide and inviting, and opens to a spacious cooltiled hall. On one side is a drawing-room, with grand piano, polished floor, and Persian rugs; water-colours are on the walls and large mirrors, all in the best of modern taste. On the other side is a dining-room, large and handsomely furnished, and behind it a cheerful morning-room, with the newest novels lining the book-shelf and the latest music on the upright piano. Bedrooms, cool and airy, open on to the wide veranda, but to see the kitchen and laundry, it is necessary to pass to a group of detached buildings in the rear. Here, too, are the quarters occupied by the bachelors, - of whom more will presently be told, - and the schoolroom, which also serves as concert-hall and chapel.

One side of the veranda overlooks a large lake of fresh water, formed by damming the course of one of the boundary streams. Flocks of wild swan and ducks feed in it undisturbed, and even shyer water fowl, such as the ibis and pelican, may often be observed upon it. From this lake, an ingeniously contrived windmill raises water to the level of an elevated platform, on which, protected by a roof of thick wooden shingles, are a number of iron tanks. From this reservoir, pipes conduct the water throughout the house and garden. From the other side of the house may be seen the wool-shed, a long building of wood with a galvanised-iron roof. Except at shearing 


\section{Squatters and Stations}

time, the shed is empty and silent. At one end are the great wool press and the bins of the woolclassers, while at the shearing-board that runs along both sides of the shed may be inspected the apparatus of the sheep-shearing machine, the invention of Lord Wesley's brother.

A ride around the run reveals signs of careful management everywhere. Each paddock contains its flocks of carefully graded sheep : in one are wethers of a certain age, and in another ewes. The stud flock occupies a domain of its own, and there is a special paddock for the horses and another for the cows. On the flats near the creek, a heavy crop of the forage plant Alfalfa is being grown under irrigation. It will presently be cut and converted into ensilage as a precaution against drought.

The permanent staff attached to the station seems disproportionately small when compared to its size and the numbers of the flocks it supports. The owner takes an active interest in his property and spends a considerable portion of each year there, bringing his life-long experience to bear upon the more important details of management. Should he be absent in town, his place is taken by one of his sons, who has possibly spent his whole life on the station, with the exception of a year or two at a public school in Sydney or Melbourne, which is held to complete the education begun by a tutor. The administration of the station is in the hands of an experienced manager, who, with 
his wife and family, lives in a pleasant cottage near the homestead. Under his supervision are the bachelors, or jackaroos, as they are usually called in the language of the bush. The jackaroos on such a station as I am describing are often young men of education and some position, who, having chosen the pastoral life as a career, are gaining the necessary experience. Some of them are "new chums," born and brought up in Great Britain, and now making their first acquaintance with Australian manners and customs. The jackaroo is the victim of all the practical jokes, and the central figure in many of the yarns told in the men's quarters. One of the best-known jackaroo stories relates to the experiences of two fresh-complexioned new chums, newly arrived at an Australian sheep-run with a whole cart-load of luggage, including a complete armoury of weapons. They had been much disappointed at the scarcity of game, both furred and feathered, and had begun to despair of finding anything to shoot. Their hopes, however, were revived by a conversation overheard between a bearded horseman and the station cook, as follows :

Cook: "Hullo!"

The Bearded One: "Hullo!"

Cook: "Anything fresh?"

The Bearded One: "Nothin' much." ( $A$ pause.) "I just saw that (adjective) jackaroo down by the water-hole again." (Another pause.) "Well, so long !" 


\section{Squatters and Stations}

Cook: "So long!"

But the new chums had heard enough. They hastily put their guns together, and crept down to the water-hole, where they found a young man of their own type, though not quite so fresh as to the complexion, sitting on a log holding his head in his hands, and groaning. The sportsmen determined to question him.

"Excuse me," said the spokesman, "have you seen anything of a jackaroo about here?"

"What the blazes has that got to do with you ?" demanded the man on the log, glaring at them.

"Oh, nothing, only we are trying to get a shot at it."

The jackaroo obtains practical experience of station life by performing all the multifarious and unpleasant tasks that come to hand. He learns to ride, if he has not previously acquired that accomplishment, and to work cheerfully all day under a broiling Australian sun. Under a good manager, he rapidly obtains a mastery of all the details connected with the management of flocks, and, in time, he may himself become manager of a station, or, if he can control the necessary capital, may stock a run on his own account.

On a run divided into paddocks after the fashion described above, no shepherds are required, but there will be one or two boundary riders, whose business it is to see that there are no gaps in the fences. Each day the boundary rider visits a different part of the run, and reports to the 
manager upon the state of the fences, the amount of water in the water-holes, and the general condition of that portion of the run. Every station has its cook, generally a man, and sometimes a Chinaman. In his kitchen is a large brick oven for the baking of bread and "brownie," the latter a station delicacy made by mixing brown sugar and currants with the bread dough. A large colonial oven, with wood fire on top and beneath it, is used for roasting, and no station kitchen is complete without a mighty frying-pan, for the preparation of the inevitable fried chops which are the staple station fare.

Another important person on the station is the storekeeper, who is usually bookkeeper as well. The station store is an interesting place, containing a little of everything, from spare parts of the sheep-shearing machinery and fencing wire down to slop-made clothes and tobacco. The store transactions are sometimes complicated, for they include the issue of clothing and tobacco to the hands as part of the wages earned, and also the issue of flour or tea, according to the bush system which is explained elsewhere, to the swagmen who may call. The storekeeper keeps the wages book, issues groceries and other supplies to the cook, and exercises a general supervision over the domestic expenditure. There are usually a few " station hands" in permanent employment, in addition to those already enumerated, but not very many. It is estimated that on a well-managed 


\section{Squatters and Stations}

station one man is employed for every seventyfive hundred sheep, an estimate which shows that the pastoral industry provides permanent work for a very small number of men proportionately to its importance.

The occasional work about a station, such as the erection of fencing or the digging of watertanks, is usually let by contract. The men who do this work have their own camp, and provide for themselves without disturbing the economy of the station, although they may draw stores (such as groceries, meats, and other supplies) against the money they earn. For the busy seasons on a station, such as shearing time, numerous extra hands are employed, on a system that will presently be explained.

There are many stations where no sheep are pastured at all, the whole run being given up to cattle. The largest of these cattle-runs are to be found in northern Queensland, where it is no uncommon thing to find a run five thousand square miles in extent. Here is bred the long-horned Australian bullock, sullen and dangerous, a wild beast rather than a domestic animal. A very different kind of station is this. The homestead is a wooden building, with a roof of galvanised iron, very hot in the noonday sun, but cooling rapidly when evening comes. It stands on a number of tall piles, and between each pile and the house is a projecting tin-plate, beyond which the destructive white ant is unable to climb. Here 
live the manager and his wife, fifty miles away from the next station and from any white man, except the two or three white stockmen employed on the run. They are assisted in their work by half a score of blacks, two or three of them "gins," who can ride or wield a stock whip as well as their dusky lords. A gin helps the manager's wife with the domestic work, and the whole company lives on beef and bread from one year's end to the other. There is no wool-shed here, only a stock-yard of solid timbers, with a branding-yard. The cattle roam unchecked, collecting in mobs by a process of natural selection, and finding their own food and water. The stockmen know where each mob can be found for the periodical musterings, when the animals belonging to other runs, known by the brands they bear, are drafted out, and the "clean skins"-unbranded stock-are made to feel the smart of the branding iron. Young bullocks are culled from the mob and sent away to the eastern coasts or down south, to be fattened for market, and surplus stock is driven off to the boiling-down works, where the beasts are converted into tallow and beef-extract. The life of the cattle-man is one long round of hardship and danger. No man, not even those brought up to the life, can account for the lunatic impulses to which a mob of bullocks is subject. Among stockmen, the "looniness " of the bullocks is proverbial, and in spite of expert horsemanship and the marvellous clever- 


\section{Squatters and Stations}

ness of their stock-horses, horse and man sometimes go down before the mad rush of some beast seized with a sudden and unaccountable fury. When camped with cattle at night-time, the men have to be prepared for sudden stampedes, which the stockmen account for by stating that bullocks see ghosts.

The stockman himself, in his characteristic dress of loose shirt, tight riding-breeches, and cabbage-tree hat, with the long stock whip coiled round his shoulders, is one of the most picturesque figures of the Australian bush. His usefulness is measured by his horsemanship and his fearlessness among cattle, for unless he possesses both these attributes in the highest degree, his value as a cattle-man is practically nil.

Station life, however, is not one long round of work and sleep. On a sheep-station such as I have described, a day's hard work in the saddle ends with a refreshing shower bath and a pleasant family dinner. Sometimes a neighbour drops in, and after dinner the men smoke on the cool, broad veranda in the pleasant dusk. The wind sighs through the big she-oaks, and from the belt of tall gum trees by the creeks comes the doleful note of the mopoke. Great flying-foxes flap silently down to the peach trees in the orchard, and tiny bats wheel and turn in the clear air, hawking the plentiful insects. One by one the stars come out, until the violet sky blazes with them. Across the lake the curlews are wailing, but 
in the drawing-room the lamps are lighted, and the cheerful sound of the piano invites an adjournment. For an hour or two, possibilities of drought or flood are forgotten, and but for the bronzed faces of the men it would be easy to imagine one's self in a city drawing-room. The evening ends at an early hour, however, for work starts at daybreak upon an Australian station.

On Sunday, Church service takes place in the schoolroom, when the owner or his representative reads the prayers, and possibly a sermon from a volume of some popular divine. When the bishop or his representative visits the station, the woolshed is converted into a church, and visitors flock in from every side. Neighbouring selectors bring in their children for baptism, and the gathering is at once a representative and a friendly one.

There are gay seasons on a station, too, when the town mansion is deserted, and the whole family, with town visitors as well, gathers in the homestead. A round of dances and picnics is arranged, and a race meeting, with a race ball to follow.

The race meeting is quite unlike anything of its kind in the cities, for it is really a picnic on a grand scale, with the addition of horse-racing. The attendance of book-makers is discouraged as far as possible, and a large proportion of the races are confined to amateur riders. Among the horses taking part in the sport may be seen some magnificent specimens of the thoroughbred, but a con- 


\section{Squatters and Stations}

dition is attached to many at the races, excluding stable-fed horses. Better sport could not be afforded than the struggles between these hardy grass-fed "walers," many of which have never known the shelter of a roof. No programme is complete without a race for shearers' horses, with owners up; and though the costumes of the riders are unorthodox to city eyes, close finishes and skilful horsemanship are the rule rather than the exception.

Station life provides other amusement besides: long drives through open paddocks and over rough bush tracks, where the clear air is aromatic with the scent of the eucalyptus and fragrant with the perfume of the wattle, wild rides through the scrub after dingoes and kangaroos, or madder gallops still after the long-tailed wild horses that sheiter in the fastnesses of the hills. Such diversions only take place during the intervals between the busy seasons. The real life of an Australian station can best be observed, however, at these periods of activity, when numerous extra men are employed, and the whole machinery of station life is working at high pressure.

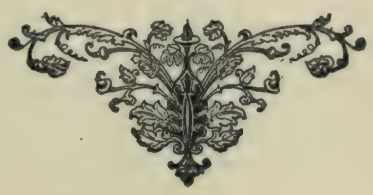




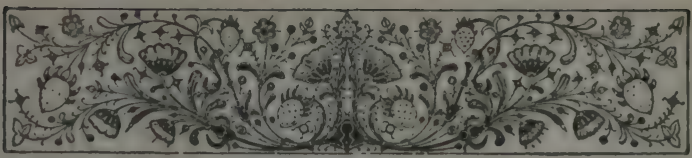

\section{CHAP'TER III}

\section{STATION WORK}

The bell is set a-ringing, and the engine gives a toot, There's five and thirty shearers here are shearing for the loot;

So stir yourselves, you penners-up, and shove the sheep along,

The musterers are fetching them, a hundred thousand strong.

Aud make your collie dogs speak up-What would the buyers say

In London, if wool was late this year from Castlereagh ?

The Banjo.

THE busiest time on a sheep-station is the time of shearing, when the annual stock-taking takes place, as well as the shearing of the sheep, and the sorting and despatch of the wool. For some time before the shearing, extra hands are employed, for a good deal of preparation is necessary. The machinery of the wool-shed has to be oiled and set in order, firewood has to be hauled, and all the water-tanks filled. In the paddocks, the flocks are being mustered, ready to be driven to the yards outside the wool-shed. Long before 


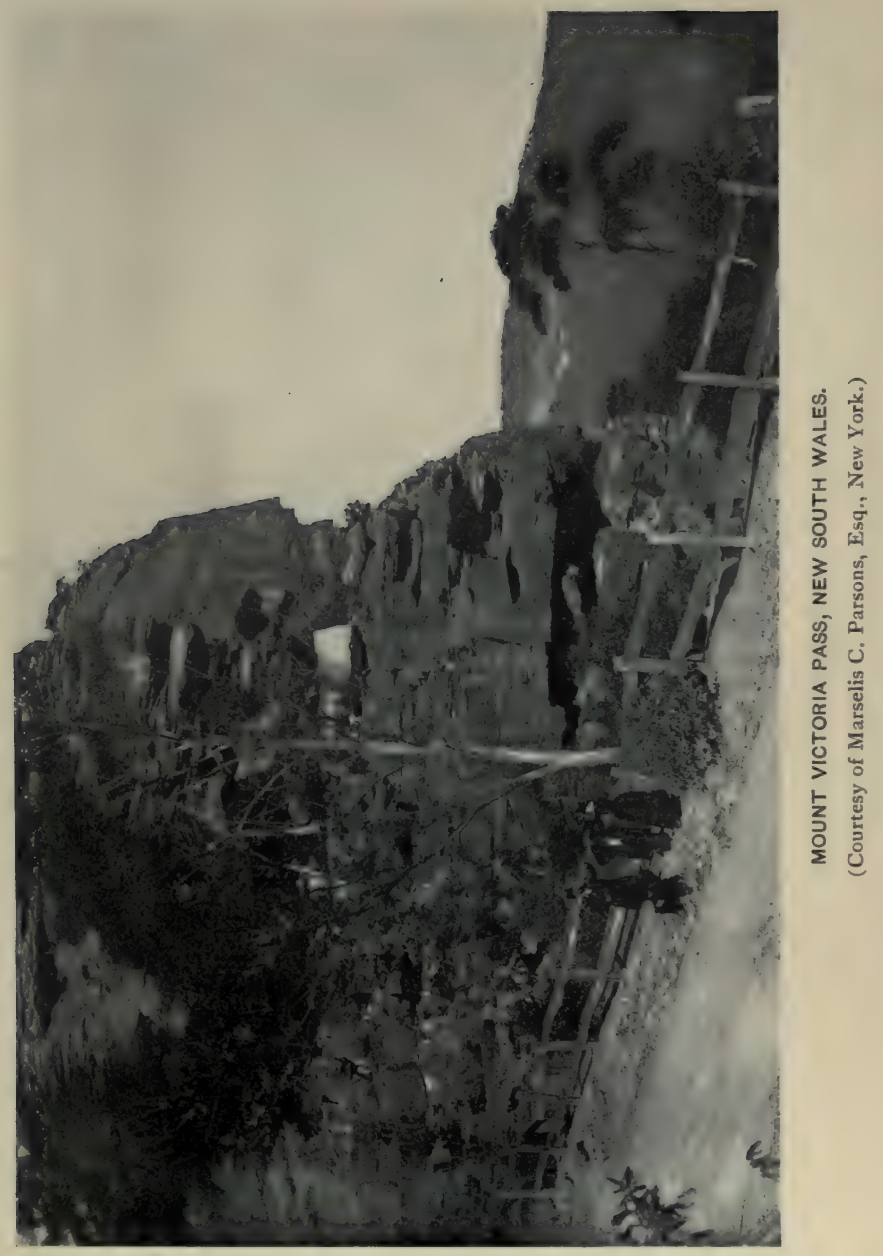





\section{Station Work}

the date fixed for commencing the actual work of shearing, all is bustle and activity on the station.

A few days before shearing starts, the shearers begin to arrive. Some come on horseback, some on bicycles, and a good many on foot, carrying their swags after the recognised bush fashion. The huts set aside for their accommodation are soon filled to overflowing, and many of them camp under tents or in the open. The shed overseer, engineer, wool-classers, cooks, and other helpers have already been engaged, and the roll of the applicants for work is called two days before the shearing starts. Those to be engaged as shearers are first selected, and sign their agreements in the presence of the manager, shed overseer, and bookkeeper. Then a number of wool-pressers and "rouse-abouts" are engaged, the duties of the latter being elastic in the extreme. Some of them are "pickers-up," removing the shorn fleeces from the shearing-board, and keeping it clear for the shearer. Others are employed in driving the woolly sheep to the yard and transferring them to the pens inside the wool-shed, in branding shorn sheep, in moving them back to the paddock, and in loading the waggons that carry the wool away. When all the men required have been engaged, the disappointed ones roll their swags and go off in search of employment somewhere else.

Shearing usually starts at the end of the week, 
on Friday or Saturday for preference. The work done by the shearers in the broken week is regarded in the light of an "exercise canter," and the Saturday afternoon and Sunday spell obviates the danger of strained wrists and backs which exists when serious work is begun too suddenly. Shearing starts at six o'clock, but before daybreak, the engine-driver and cooks are at work, the former getting up steam to drive the machines, the latter preparing the coffee and buns with which the shearers break their fast. At six o'clock, everybody is in the shed, the pens are full of sheep, and the shearers, two to each pen, stand on the board. The engine whistle gives a shrill toot, the machinery is set in motion, and each shearer dives into the pen to catch the sheep he has selected as the easiest to shear. Grasping his victim by the leg, the shearer drags it out of the pen, quiets its struggles by a deft application of his knee, and gets to work with the shears. The fleece falls off the animal in one great piece, and in a surprisingly short space of time it is released, pink and shivering, to make its way along the race and out into the yards again. The pickers-up fly to remove the fallen wool, and the shearer plunges into the pen again in search of the easiest-cutting animal left there. As the pens become emptier, the sheep left are harder to shear, and the last animal of all, called the "cobbler," is looked upon as an object to avoid. If a very undesirable specimen, the manœuvres of the two 


\section{Station Work}

shearers are amusing, each being anxious that the "cobbler" shall fall to the other.

Up and down the board walks the shed overseer, with an eye upon every man there. He sees that the "penners-up" do not leave a pen empty for one moment, that the pickers-up are keeping the board clear, and above all, that the shearers are doing their work properly. It is of the utmost importance that each sheep shall be shorn closely and evenly, uneven shearing resulting in waste "tip" to the wool of the next season. The shearers, who are paid according to the number of sheep shorn, will scamp their work if not properly supervised. The rivalry among them is very keen, and there is sometimes close competition for the position of "ringer," as the man whose total of shorn sheep at the conclusion of the shearing is the highest, is called. Occasionally a man in his haste and in his anxiety to shear close will cut a piece of skin from his sheep, when a boy with a pot of mixed tar and grease will be called to daub the wound of the suffering animal. In the old days of hand-shearing, the tar boy's services were more frequently in requisition than under the modern system of machine-shearing, now in vogue at all the bestmanaged stations.

At eight o'clock, work is suspended for the first of the many meals the shearer manages to devour during the course of the day. The shearers' cook is always a competent man, and supplies his 
clients with the best fare obtainable, utterly belying the name of "poisoner," usually bestowed upon him. He has to cater for a very fastidious company, but he is well paid for his work, and can afford to ignore a good deal of captious grumbling. The shearers themselves earn splendid wages while at work, the standard rate being one pound for each hundred sheep shorn. A good shearer can average a hundred a day taking the easy work with the hard, and under exceptional circumstances, tallies as high as three hundred in a day have been made. This, however, is a notable piece of work, and the names of the men who have performed such exceptional feats are known throughout pastoral Australia, "from the Gulf to the Bight." Even when living upon all the luxuries at his command, the shearer's expenditure rarely exceeds one pound per week, so that the men usually have good cheques to draw when the shed has "cut out."

Each fleece is taken by the picker-up to the table of the wool-roller, who trims it neatly, removing the dirty edges, and rolls it up for the inspection of the wool-classer. This expert decides on the quality of the fleece, and places it in one of a number of bins, each bearing a distinguishing letter denoting the quality of the wool it contains. The bins are from time to time emptied by the wool-pressers, who bale the wool with the aid of the big press, marking each bale with the quality of the wool and the station brand. The bales are 
loaded upon waggons and conveyed to the nearest railway-station; or to a river-staging, where they are piled upon a barge, which is towed by a little side-wheel steamer down to the river Murray.

The shorn sheep are counted and branded, and in many cases dipped to prevent their picking up tick and other parasites. Then they are drafted into classes and moved to the paddocks, where they remain until the time comes when another crop of wool has to be shorn from them. By the counting of the sheep, the owner is able to compare the numbers of his flock with those ascertained at the previous shearing, and so to estimate their rate of increase, or, as the case has too often been of late years, their rate of decrease. The end of the shearing is usually celebrated by an entertainment, consisting of athletic sports, races of the shearers' horses in the afternoon, and a concert in the wool-shed in the evening. The concert usually takes the form of a burnt-cork entertainment with a number of highly original and diverting turns thrown in. Some of the shearers are masters of most curious accomplishments, such as axe-swinging and bell-ringing. I once heard a man play a number of tunes upon a row of billy-cans of different sizes, each containing a certain quantity of water, the notes being sounded by tapping the cans with a small wooden hammer. An invariable feature of these entertainments is a collection, the proceeds being devoted to the benefit of the nearest hospital, and the shearer, flush 
with money at such a time, seldom fails to contribute liberally. When shearing is over, the men are paid their cheques, and the station reverts to its normal condition and regular daily round of work.

The busy time on a cattle-station is the general muster, a time of the greatest excitement and anxiety. First comes the driving of the various mobs to the "camp," a work accomplished with as little whip-cracking and flurry as possible, for the object in view is to prevent the animals from becoming excited or unmanageable. When the cattle are all collected, the work of "cutting out" begins. The cattle are packed together, some of them wild with fear and disturbing the others by their bellowing and sidelong thrusting of the horns. Into the mob rides the stockman, intent on separating from it some particular animal he has picked out. The well-trained horse forces his way through the cattle, obedient to every touch of knee and rein. Soon he has grasped his master's purpose and begins to edge the beast singled out towards the outside of the throng. It is a dangerous work, but man and horse have confidence in each other, and both are alert and watchful. Now the beast to be cut out is one of a dozen on the edge of the pack, and with a crack of his whip and a yell the stockman drives his horse between them and the mob, separating them from it. They try to return, and those not required are allowed to do so, but the beast that is to be cut out finds, wherever he turns, that whip and horse 
are in his way. Soon he is galloping in the direction the stockman has chosen, and is added to the mob of cattle to which he rightly belongs. Then back go man and horse to the press again, to repeat the exciting work. After the cutting out is done, and the beasts have been sorted in mobs according to their classes, each mob is made to "string" or move in single file, in order that a count may be made. Last of all comes the branding of the "clean-skins," an operation performed with much heating of irons, an overpowering odour of burning hair and hide, and a frantic bellowing on the part of the persecuted oxen.

If the good qualities of the stock-horse are to be thoroughly appreciated, he must be seen at this work of cutting out, or the equally stirring performance of running wild horses. The "brumbies," as the wild horses are called, are usually to be found in the hilly districts, and their existence on a run in any number is soon made apparent by the amount of pasturage they consume. Then the run-holder may arrange to clear his run of them, by calling in a band of men who make the capture of wild horses their profession. Operations are begun by building a stout stock-yard in a position chosen with regard to the known habits of the horses. On the day appointed for the "running," there is no lack of volunteers willing to try the speed of their horses against that of the brumbies. The position of the mob of wild horses has been carefully marked, and with equal care 


\section{6}

plans have been laid for the course along which they are to be driven. The whole success of the operation depends upon the carrying out of these plans. And now the brumbies are off, heading straight for the roughest part of the range of hills, while every horseman in pursuit is getting as much as possible out of his mount. Those best mounted forge ahead, and ride for the flanks of the flying mob of "long-tails," where stock-whips are presently cracking as the men strive to turn the terrified animals. Now the herd is tearing down a steep declivity, threading between trees and boulders. It is the chance of the mounted men, for even the wild brumbies are not so surefooted as these stock-horses. One or two of the boldest riders are at the foot of the descent before their quarry, and check them with skilfully wielded stock-whips. The others press closer now, and the wild animals are turned, checked and lashed and harried into a state of exhaustion. Like a mob of driven cattle, they are forced into the stock-yard, although at the sight of the fencing the wildest of them make a last effort for freedom, and two or three may probably break the cordon and escape at the last moment. The value of the brumby may be judged from the fact that a good stock-horse, carrying a full-grown man, can both outpace and outstay him. Some of them are easily broken to both saddle and harness, but others remain incorrigible "outlaws," in spite of the forcible methods of the horse-breaker. 


\section{Station Work}

Most stockmen understand the breaking of young horses, and on stations where horsebreeding is carried on to any considerable extent, there are usually one or two men well qualified for such work. The methods employed are of the roughand-ready order, little time being wasted in preparing the unbroken animal for the ordeal of being mounted. Once in the saddle, it is the rider's object to enforce his mastery, applying whip and spur with relentless energy at any sign of rebellion. I can recall from my own boyhood a picture of one of these horsebreakers, whom we only knew as "Sydney Bob" - an undersized man, but deepchested and strong of arm, and with a weatherbeaten face that expressed strong determination. In his dress, Sydney Bob was "flash," addicted to tight cords and neat boots, a brilliant scarlet handkerchief knotted around his throat, and a wide-leaved cabbage-tree hat. The particular incident with which he is connected in my mind was the riding of a young bullock down the main street of a small township near Ballarat. The ride was the outcome of a wager, and the feat was made more dangerous by the fact that the rider had one arm in a sling, probably as a result of a fall from some unbroken horse. The bullock was hemmed in in a small yard of the local sale-yards, and the first notice he received of the wager of which he had been made the subject, was to find a man astride his back. The panels were let down, and the bullock rushed out into the street 
with Sydney Bob, facing the wrong way, vigorously twisting his tail with the uninjured hand. As the maddened beast tore down the street, his rider could be heard shouting his war-cry of-

\section{Blow me, dontcher know me? \\ I'm Sydney Bob, the rider.}

From that freak, he escaped without injury, although I believe he met his death as a result of one of these mad wagers. In his day, this man was a notable rider of "buckjumpers," and a wellknown character at horse-sales.

Among the most skilful of horsebreakers are the rough-riders attached to the Australian police departments, which annually purchase large draughts of valuable young horses for the use of the mounted police. Among a draught I once saw handled by the police rough-riders, was a buckjumper which gave a most extraordinary exhibition of his accomplishments. He did not look the part at all; otherwise, he would never have been purchased for the purpose of a trooper's mount. This horse allowed himself to be saddled with a meekness that his experienced rider evidently considered suspicious, for he was obviously prepared for the performance which followed. No sooner had he thrown himself into the saddle than the horse sprang into the air, ducking his head and arching his back with a ferocious energy. Four times he leaped into the air, bucking until it seemed that the stout girth would break. Find- 


\section{Station Work}

ing these tactics useless, he broke into a mad gallop, and then, with a sidelong leap, he once more arched his back like a bent bow. Then he reared up on his hind legs, threatening to fall backwards upon his rider. Finally, he did throw himself upon the ground, but the man's skill saved him from being crushed, and when the animal rose to his feet again, it was only to find himself still burdened with his hated incubus. $\mathrm{He}$ continued to struggle until he was thoroughly exhausted and allowed himself to be ridden around the riding-school. Then the rough-rider dismounted. "An outlaw," said he, "and a bad 'un at that."

Another familiar figure on the station is the rabbit-trapper, with his waggon, his wire netting, and his spring-traps. At one time, when the trapper received payment from the squatter for the scalps of his slain rabbits, these men might earn as much as $£ 20$ a week in the badly infested districts. It is said-and there is good reason to believe it-that many of these men deliberately spared the female rabbits, declining to put an end to such a lucrative employment by readily helping to stamp the rabbits out. The pastoralists were helpless in the face of the law; which was afterwards modified, when the rabbit-trappers' era of luxury came to a sudden end. At that time, the commercial value of bunny was practically nil, but the use of his fur in the manufacture of felt hats and the improvements made in the transport 
of frozen meats have given a new lease of life to the occupation of rabbit-trapping. Many millions of rabbits are now annually exported from Australia, and even more are poisoned for the sake of their skins. Wherever there is railway communication, the once-despised rabbit is now regarded as a source of employment and revenue. In such districts, the rabbits are being kept well in check, as the trappers are glad to undertake the work for the value of their catch. An experienced man, with a proper outfit of cart, horse, and wire-netting traps, can make from $£_{3}$ to $£_{4}$ a week, though he has to thoroughly understand his work if he is to earn so much.

The fox was introduced into Australia to make war upon the rabbits, and has made himself thoroughly at home there. He prefers poultry to the rabbit, and has become such a nuisance in the farming districts that rewards are paid for his scalp. In one district alone, over thirty thousand foxes were killed in the year I9or, though these animals, like the dingoes, show the greatest cunning in avoiding poisoned baits laid for them. For the scalp of a dingo, as much as twenty shillings will be paid, and the pastoralists are glad to get rid of the brutes on such terms, for their depredations at lambing time cause heavy loss wherever they are at all plentiful. The mistaken enthusiasts who introduced rabbits and foxes into Australia can at least point to others as mistaken as themselves. There is, for instance, the house 


\section{Station Work}

sparrow, a very undesirable emigrant who has invaded the country districts and proved himself destructive and a nuisance. He was introduced to Australia as an insect killer, but careful examination of his diet shows that only three and a half per cent. of it consists of insects. The rest is grain and seeds. This fraud multiplies at an unheard-of rate, and persecutes and drives away the less hardy native birds. Among vegetable pests, the prickly pear is perhaps the worst, although in the worst of the great drought it was shown to have its uses. The Scotch thistle is another imported plant, which has spread itself far and wide, choking the valuable pastures, and rendering large grazing areas useless. The dog-rose, or sweet-briar, has played the same part of unwelcome guest, and there are further instances that could be adduced in justification of the coldness with which Australians now regard any attempt to acclimatise a new animal or plant, the use of which is not plainly apparent.

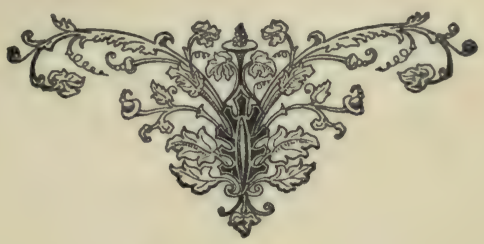




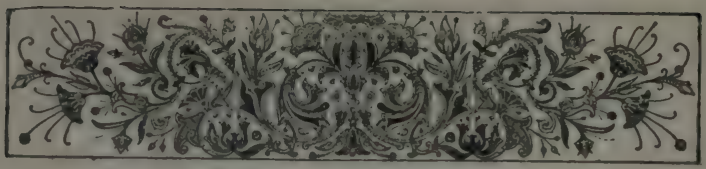

\section{CHAPTER IV}

\section{ON A SELECTION}

She helped him make a little home, Where once were gum trees quaint and stark And blood-woods waved green-feathered foam, Working from dawn of day till dark, Till that dark forest formed a frame

For vineyards that the gods might bless; And what was savage once became An Eden in the wilderness.

VICTOR DALEY.

EOR the origin of the term "selector," we must go back to an Act passed by the New South Wales Parliament in $186 \mathrm{r}$. Ten years had passed since the gold discoveries, and many of the immigrants were clamouring for land for farming purposes. A Land Act was accordingly passed permitting the "selection" of blocks of land from forty to three hundred acres in extent, to be purchased from the State by the selector on a system of instalment payments. The Act even allowed the selection to be made on areas leased as pastoral holdings, and soon the squatters found the selectors occupying the most fertile and best- 


\section{On a Selection}

watered patches on their runs. Thus began a feud between squatter and selector, which is vigorously maintained in some places at the present day. In addition to the three hundred acres he may obtain by purchase, the selector can "take up" an additional area of three hundred acres on leasehold, and may further expand his holding by selecting in the name of his children under certain conditions. By these expedients, the selection can be made to assume very respectable dimensions, and frequently its size hampers the selector in the struggle upon which he enters to make for himself and his family a home in the bush.

In the vernacular of the bush, the selector is a "cockie," and cockie is short for cockatoo farmer. $\mathrm{He}$ is a cockatoo farmer because he works early and late to clear a patch of ground, and plough it ; then he sows his seed, only to wake at dawn the next day and find his field white with cockatoos, all busily devouring the grain. Those cockatoos are the only crop he has, "of all his labour and vexation of his heart wherein he hath laboured under the sun." If not cockatoos, then rabbits, or locusts, or drought interfere to deprive him of the result of his work.

The typical cockie's hut is remarkable for the size of its clay fireplace, which is usually the nucleus of the structure. Planning on an ambitious scale, the cockie builds his fireplace first, from bricks made of puddled clay dried in the sun. To this he builds a hut of two or three rooms, with 
sapling uprights and boarding of shingles from the splitter's camp. Slabs of bark make the roof, and the only materials purchased are a couple of glazed window-sashes and a door. The bare earth serves as floor, a slab table is knocked together and a home-made form, and two or three gin-cases serve for chairs. Beds are made by stretching canvas or hessian upon sapling frames, and the house is ready for occupation.

The cockie himself is a young Australian, who has had several good seasons in the shearingsheds, and has been steady enough to save his cheques. His wife is a bush girl, jolly, fond of fun and dancing, and equal to any emergency. Chopping wood, milking cows, riding barebacked horses, and killing snakes are among her many accomplishments, all of them of the greatest use on a selection. Her domestic utensils are interesting. First comes the camp oven, a large iron pot with three short legs and a close-fitting lid. The camp oven is placed in the fire, the ashes are heaped over it, and anything can be baked in it from a loaf of bread to a leg of mutton. An iron bar stretches across the fireplace, from which there hangs by a hook the griddle-a plate of iron on which scones and bannocks can be rapidly baked. The inevitable frying-pan and billy-can complete the list, unless a boiler improvised out of a large paraffin tin be included. The same simplicity characterises the rest of the household equipments, for the bush home is a 


\section{On a Selection}

standing argument in favour of the contention that many of the supposed necessities of civilisation are in reality but superfluities. With a dozen sheep, a few cows, and a patient old horse, the cockie and his wife settle down to the work of clearing and fencing their holding, brave and resolute, and happy if they have but a few pounds in the bank to keep them in their initial struggles. So much for the beginnings. Let us now visit a selection which has been taken up for some years. There is the same hut, now sadly dilapidated, and with a lean-to added to serve as a dairy, and another roughly constructed room to provide sleeping accommodation for the growing family of children. The selector may be able to afford a much better habitation, and probably intends to provide one. He will talk of a situation he has chosen, superior in every way to that he now occupies. His wife, faded and prematurely aged with the hard work, or the worry of a large family, looks forward with a pathetic cheerfulness to the change. Meanwhile, what is the use of trying to improve the old house? So the bark roof continues to leak, and the earthen floor to become mud, while the door will not shut, or will not open. These things are ignored as the selector talks of the conveniences of the new house he means to build. A walk around the selection shows that its owner is master of every imaginable makeshift. "Dog leg" fences, made of long saplings, supported on improvised and shaky 
trestles, run crookedly between the paddocks, inviting the stock to break through and stray. Valuable machinery for harvesting lies unprotected and rusting in dew and rain, waiting for the shelter-shed its owner is just going to erect. The women folk have to carry thieir water from the creek a quarter of a mile away, although a pure and better supply could be obtained by sinking a well near the house. The cultivation paddocks bristle with stumps, the standing crop is fringed with a border of dry grass, which might safely be burned off on a still day. Some hot night the north wind will drive a bush fire upon the selection, and the selector and his family will have to fight the flames along that fringe of dry grass, or see their year's work licked up by the fire. Everything speaks of procrastination and makeshift; his very occupation of the soil is regarded by the cockie as only a temporary permanence.

The day's work on the selection begins at "piccaninny daylight," when the stars are still shining in the grey sky, and the birds are uttering their first sleepy calls. Down into the horsepaddocks goes the eldest boy. Having caught the quietest horse, he throws a sack across it and drives the rest up to the yard. He slips a saddle and bridle on his riding-horse, and at once sets off to bring in the cows. By this time, the whole bush is awake. A party of kookaburras, perched on the big swamp gum tree by the creek, are laugh- 


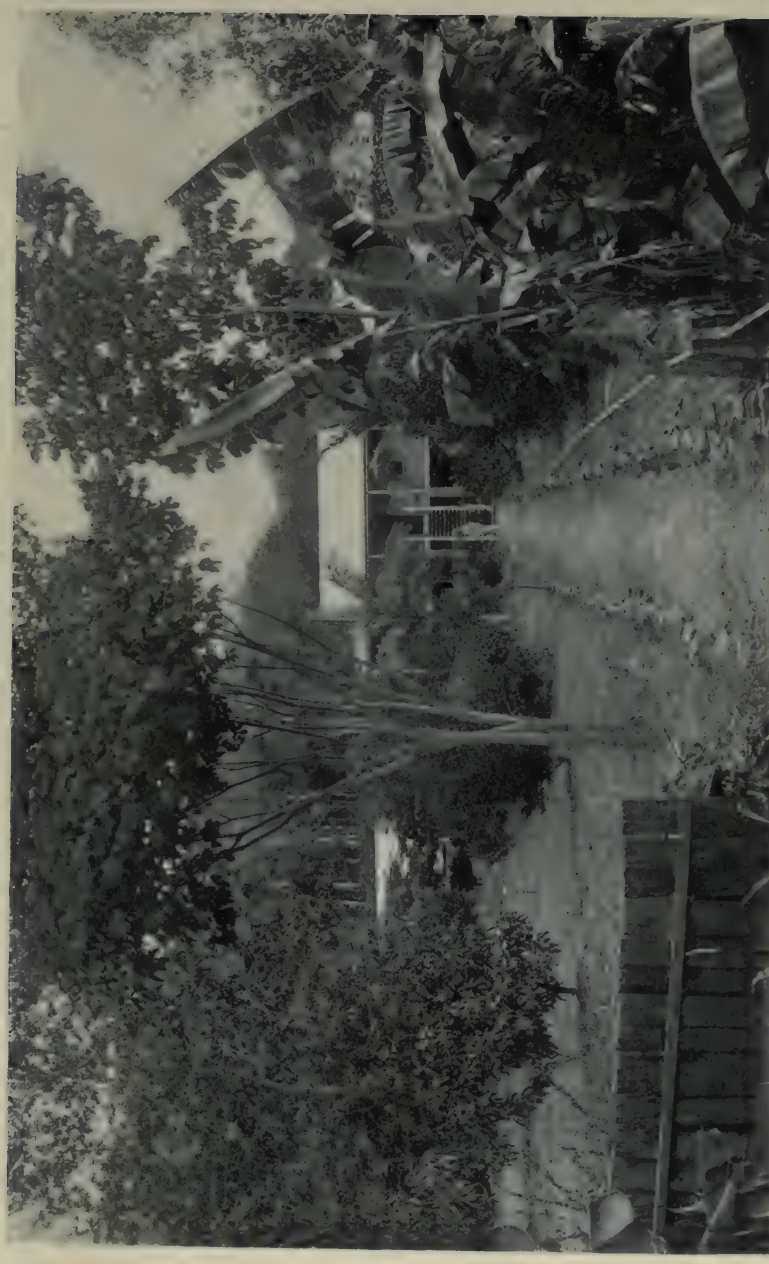

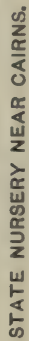





\section{On a Selection}

ing at some joke of their own, and across the flats the magpies are fluting and carolling out of sheer joy. Green parrots dart in shrieking flocks from tree to tree in search of honey-laden eucalyptus blossoms. Startled by the hoof-falls, a grey wallaby hops through the scrub, making gigantic leaps in its fright. The boy tears off a twig of eucalyptus to brush away the tormenting flies, and with many a yell and shout drives the lowing cows into the yard.

Then comes the work of milking, in which every one takes part. When it is finished the boy has his breakfast, while his father harnesses a horse to the spring-cart, in which the milk, in a large tin vessel, is to be conveyed to the butter factory. The money received for the milk is the only regular source of income the selection can boast, and the institution of these butter factories has done much to make existence possible for the selector. It would be interesting to trace the butter from the factory to the big cool-storage depot in Melbourne or Sydney, and thence to the refrigerating chamber of an ocean-going steamer, to appear presently on some English or African breakfast-table. Meanwhile, having seen the milk despatched, the cockie sits down to a breakfast of milkless tea and butterless bread. Presently, the boy returns with his vessel of "separated" milk for the consumption of the calves and pigs; and now it is time for school.

Anxiously the mother watches the children set 
off along the bush track, each child with its dinner and bottle of water in the bag with the school books. It is four miles to the little school near the main road, and the mother sighs as she thinks of the snakes and other dangers of the track. That is part of the bush training, however, and helps to make children fearless and resourceful. She has other things to think of, calves, pigs, and poultry to feed, and dinner to prepare. Her husband rides off in quest of some straying stock, and to mend the gap in the field through which they have escaped. He meets his neighbour, who is on the same errand, and a long conversation ensues regarding the slackness of the Road Board, the increase of rabbits in the district, and the remissness of the local Member of Parliament. The cockie is an ardent politician, and is only diverted from his subject by the arrival of the local grazier, who repeats a long-standing offer for some sheep which cockie number two has for sale. After the usual chaffering, the matter is allowed to remain open, and all three go off to their work.

At midday, dinner is ready, and may consist of beef salted and boiled, the remnant of a beast killed some time before. A plentiful allowance of pumpkin is served with it, for the pumpkin patch repeats itself every year, the self-sown plants thriving in a manner only possible where the soil is very fertile. The scheme for a new house includes a large vegetable garden, where onions, tomatoes, and cabbages will grow luxuriantly, 


\section{On a Selection}

but, until then, the pumpkin is the staple vegetable. Dinner is washed down with plenty of scalding tea, after which the selector lights his pipe and goes off to work again. During the afternoon, a swagman comes to the door, with the stereotyped question, "Any chance of a feed, missus?" He is introduced to the wood heap and a blunt axe, and if he is a genuine man,-and he generally is, - he chops a pile of wood and carries water from the creek while the inevitable tea is being prepared. A meal is set before him, and he eats ravenously, chatting between mouthfuls concerning the state of the country he has just traversed. A pannikin of flour and a "bit o' tea" send him on his way satisfied, to camp for the night in a clump of low timber further along the track.

And now the shadows are lengthening, and the selector's wife goes down to the slip rails to wait for the post-boy, who may have a letter or paper for her. That bush Mercury comes ambling along the track on his dusty pony, and, shaking his head in reply to her questioning look, rides by with a cheery "Good evening." Shading her eyes from the setting sun, she sees the children straggling home from school, and turns back to the house to get their tea ready. Then the cows have to be milked once more, and the young stock tended, which occupies everybody until it is quite dark. The mother sets about putting the children to bed, but the eldest boy whistles to his dog, and 
takes up his old single-barrelled gun, looking wistfully at his father. The latter "does n't see why he should n't," and the pair go off amicably in search of 'possums, the skins of which will be tanned and converted into a fine serviceable rug. They are soon back, though, and at an early hour all are in bed, enjoying a well-earned rest.

The bush folk have few pleasures, but they cannot be said to take them sadly. They rather make the best of things. When Christmas time comes, the boys go off into the ranges and cut young cherry trees-which are not cherry treesand big fern leaves to decorate the house with a brave show of green. A great slaughter of poultry and sucking pigs takes place, and puddings are boiled and cakes baked in readiness for the holiday. Old friends come riding in, and brothers who were away droving or shearing turn up unexpectedly, and sleep on shakedowns before the kitchen fire. There is a good deal of eating and jollity, and in the evening a visit is paid to a neighbour's house, where the young people dance to the strains of a concertina, while the staider married folk gossip together, the men smoking their pipes outside and discussing their unfailing politics.

On Boxing Day, the selection is left to look after itself, and the whole family drives off to the "sports" in the spring cart. There is provisioning on a liberal scale from the substantial remnants of the Christmas feast, and the family 
picnics happily under some shady gum tree. The sports provide plenty of excitement, and if the selector's driving on the homeward way is reckless and erratic,-well, it is not often he meets so many old friends on one day. Show Day is another bush holiday very generally observed. There is much competition at that time in live stock of all kinds, and prizes may be won by housewives proud of their home-baked bread or their home-cured bacon and hams. The country is looking its best at show time, for shows are held in the early spring, when there are hopes of good crops and a plentiful increase of live stock and poultry. These are the interludes that break the monotony of the selector's life, and prevent him from losing touch with old friends, and becoming soured by the anxieties, disappointments, and losses he has so constantly to face.

Each summer brings for him its harassing dread of bush fires. He watches the grass turn brown beneath the scorching sun, and counts the days until his standing crop shall be ready for harvest. The passing swagman is an object of painful interest, for a carelessly dropped match or a camp fire left unextinguished may precipitate a disaster. At last, the wheat is cut and stacked in stooks about the paddock, and the cockie works feverishly to get it carted away to the thrashingmachine at work in the nearest township. Then he breathes more freely, though he has still much to lose. The earth cracks with the summer heat, 
week after week brings no rain, and the hot north wind is charged with a smell of burning greenery. Then, one evening, when the sun goes down a fiery crimson ball, a red glare warns him of the approaching danger. All the live stock, kept near the house as a precaution against such an emergency, is quickly driven into the bare yard, and then the settler and his family cut branches to beat the fire out. It comes down on them with incredible rapidity, first a cloud of choking smoke shot with sparks, and in a moment the dry grass beneath their feet is crackling into flame. They beat the fire out with their green branches, scarcely glancing at the pranks it is playing all around them. The flames run up the loose hanging bark of a big gum tree, and it bursts into a sheet of flame, threatening the little homestead with burning branches falling from above. It reaches the dry stubble and sweeps across it with a glad roar. Three weeks ago, the crop would have met with the same fate, but the settler and his family have no time to notice these things. They beat the flames down, walking among them with singeing clothes and blistering hands. They are fighting for their home, and the terrified animals that huddle around it in helpless terror. Some neighbours, fortunate enough to be out of the zone of fire, come riding at top speed down the tracks to their assistance. Just in time, too, for the dry fencing is all ablaze, and the fire ring is closing in. Buckets of water are hastily 


\section{On a Selection}

brought, and the branches do their work more effectually after a drenching. The fight is resumed with new vigour, for the worst of the fire has passed. It is sweeping through the country a mile away, leaving in its track a wake of blazing trees, charred fences, and blackened soil. But the home is saved and the stock as well, and the settlers, with blackened faces and smoke-reddened eyes, congratulate one another that it is no worse. Next day, the selector is able to estimate the extent of his misfortune. Fences burned everywhere, not a mouthful of feed left on his selection to keep the stock alive until the rain comes. Ah, well! it might have been worse. He must pay for pasturing the stocks in somebody's paddock until the grass shoots again, and he is lucky to have saved his crop and so to be able to find the money.

Bush fire is not the only disaster the selector is called upon to face. The rainy season may swell the little creek that runs through the selection until it overflows its banks, and floods the paddocks. Then the selector looks across a waste of waters, and can only hope that they will not cover the little islands of high ground where his animals have taken refuge. He may work hard with his neighbours to carry out the instructions issued by the Government for the destruction of the eggs and young of the locusts, only to find his green crop devoured by a swarm nurtured somewhere else. Rabbits and other pests, both animal and 
vegetable, are always with him, and he sows his seed without any certainty of reaping a harvest. There is little cause to wonder that this uncertainty has made the selector a fatalist with a creed of "what is to be will be." His makeshifts, his procrastinations, are only his preparation for some final disaster, which may leave him beaten and penniless, to take up the thread of existence bravely in some new place. He fights doggedly on, but he digs no garden, and plants no pleasant shade trees around his bush home. He has an ideal of a land where the seasons are regular and life can be well ordered and arranged without the necessity of pitting the work of a year against the caprice of nature. Sometimes, when drought and hard times press too severely upon him, he sells out and emigrates to Canada, South Africa, or the Argentine, in the hope of finding his ideal there. But he usually struggles on, with the hope of better times before him, fighting drought, bush fire, and the mortgagee with a dogged courage worthy of all success. The Australian newspaper man delights to write of the selector as the "backbone of the country," and, as usual, the newspaper man is not far away from the truth.

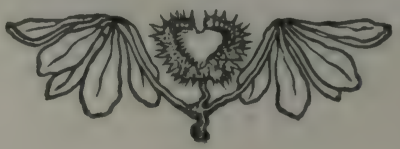




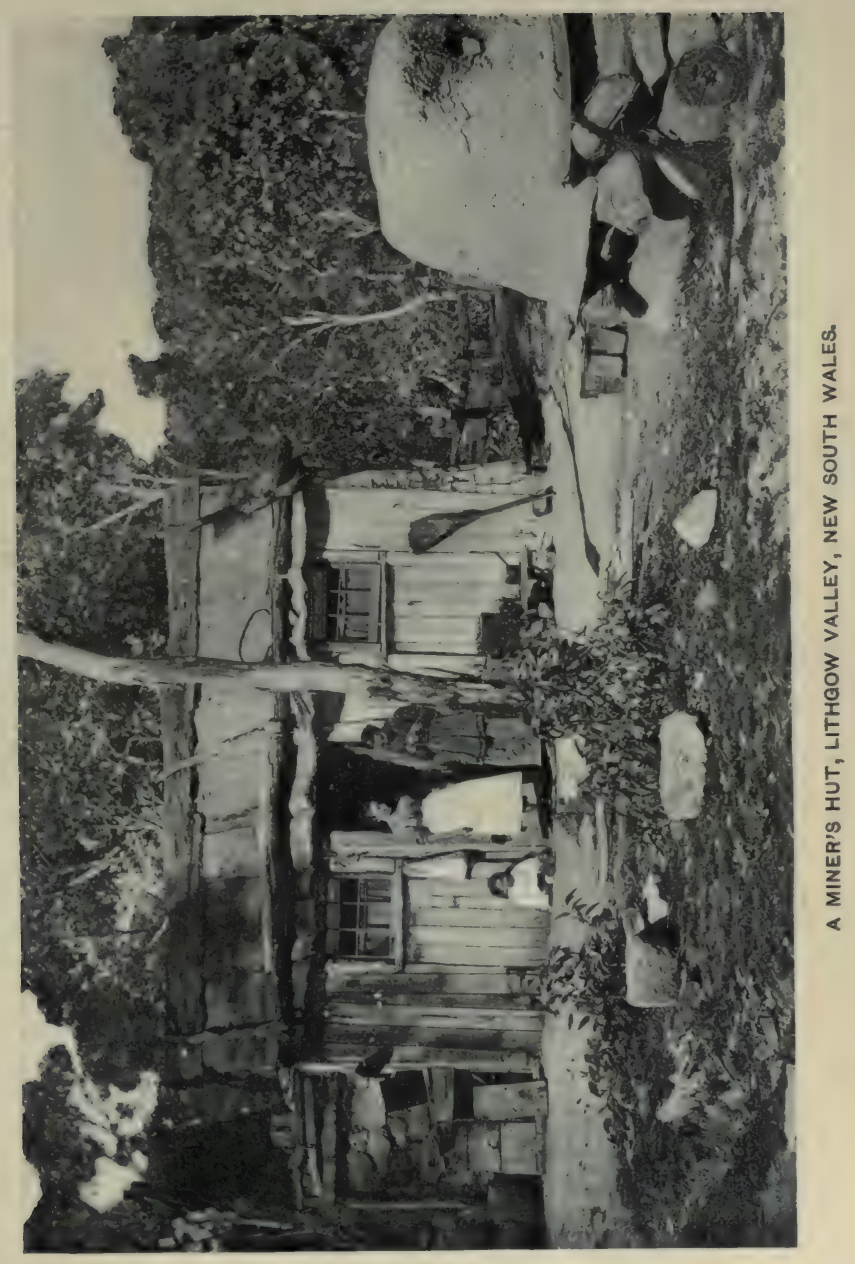





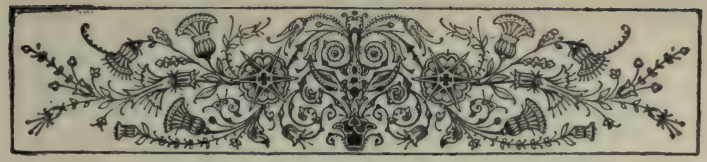

\section{CHAPTER V}

\section{THE NEVER-NEVER IAND}

They had told us of pastures wide and green,

To be sought past the sunset's glow, Of rifts in the ranges by opals lit, And gold 'neath the river's flow.

And thirst and hunger were banished words, When they spoke of that unknown West; No drought they dread, no flood they feared, Where the pelican builds her nest.

MARY H. FOOTE.

$M \begin{gathered}\text { ORE than one-half of Australia consists of } \\ \text { country still unexplored or only partially }\end{gathered}$ explored. Across the unexplored portions there are written on the map such words as "great sandy desert." Year by year, the dimensions of these map areas are being reduced, and more is being learned of the nature and resources of those uninviting wastes from which the early explorers turned back in despair, or where they laid down their lives in the vain attempt to fathom secrets that are still unsolved. The mystery of that unknown region makes its appeal even to the Australian who spends his life in the fringe of settled 
land that lies along the sea-coast. To the bushmen who have seen it, now fair and smiling, and decked like a garden with glowing flowers, and again a forbidding and arid wilderness, the NeverNever Land, unknown and only partially known, is a magnet that draws them on to adventure. It holds fortune, and it holds death.

\section{On the plains of the Never-Never, That's where the dead men lie,}

wrote Barcroft Boake. For more than fifty years, the Never-Never Land has held one secret that many bold men have failed to wrest from it-the fate of Ludwig Leichhardt. In I848, Leichhardt set out from the Darling Downs in Queensland, following the course of the river Barcoo, with the intention of striking west across Australia in the direction of Perth. He and his party were swallowed up by the desert, and from that day to this, their fate remains a mystery. Expeditions were fitted out in the hope, at least, of tracing them to their last camp, but in vain. No explorer goes out at the present day without some faint expectation of discovering an explanation of their total disappearance, but not one vestige of the expedition has been found. And Ludwig Leichhardt is but one of the many victims of the Never-Never Land.

If the risks are great, the rewards also are great. In the year 1892 , two prospectors named Bayley and Ford, both good bushmen, ventured a little 


\section{The Never-Never Land}

further than their fellows away from the edge of the known country into the heart of the unknown. Three months later, the whole world was talking of the richness of the new Coolgardie goldfields, and the two bold adventurers were the owners of the famous mine called Bayley's Reward, which produced ore that held more gold than stone. Ten years later, a big city, lighted by electric light and connected with the far-distant coast by a long railway, stood on the ground over which they had been the first white men to walk. A big slice was lopped off the western edge of the NeverNever country by the enterprise and daring of those two successful prospectors.

It is characteristic of Australian hopefulness that the pastoralist as well as the prospector has found his way into the half-known country, and is pasturing his sheep and bullocks on some of the most fertile parts of it. The conditions of pastoral life in these remote back stations contrast strangely with the luxury and convenience of the homes of the squatters who settled in the early days on well-watered runs near the coast. A small wooden house, with a glaring roof of galvanised iron, stands in the midst of a wilderness of scrub. The furniture of the hut-it is little more-is of the most primitive description, for the manager is a bachelor, and so are the jackaroos and the few station hands. There, from one rainy season to another, these men are engaged in their desperate struggle to keep stock alive, 
always hoping that the next season will bring better fortune; that is, more rain. They have water, at least, although it is muddy and yellow, or has to be boiled and skimmed before they may drink it. But all around them there is a belt of bad country, so dry that it is impossible to move their stock across it, if they wished to. Their stores come to them once every three months by camel-train, and the sight of a fresh white face is a rarity. There is little cause to wonder that, after a time, this isolated life of hardship has its effect upon the character of the men who lead it, and that some of them become morbid and others hopeless and desperate.

When the long-expected good seasons at last come, these outback stations begin to justify their existence. Soon there is plenty of feed everywhere, and the listless sheep and hollow-sided cattle become round and sleek. Eiven in the worst of the bad country there is at last some feed and water, and now is the chance to send all the surplus stock to market. This is the busy time of the drovers. On these stations in the NeverNever country, the marketable cattle have perhaps been accumulating for three years, and now in mobs of a thousand or more they are being despatched from the far-away Gulf country to the Southern and Eastern markets. Each mob is in charge of a band of stockmen, who think nothing of a three months' journey across the silent central plain behind their restless herd of cattle. In ad- 


\section{The Never-Never Land}

vance of the mob, the cook drives his cart, ever on the look-out, as nightfall approaches, for a suitable place for the camp. Behind the cart, a few spare horses are led in halters, for the use of the eight or ten mounted drovers in charge of the herd of cattle that follows. See them coming, a thousand great lumbering bullocks, packed in one dense mob, with the men, tanned and picturesque, sitting so easily on the clever stock-horses. Every man has his eyes upon the herd, for they have not been long upon the route, and are awkward to drive because they have not yet found their travelling legs. The stock-whips sound from time to time with a report like the discharge of a rifle, as some discontented animal makes an attempt to break away from his fellows. In another month or so, if all goes well, the bullocks will have become used to travelling, and the necessity for constant vigilance will have ceased to exist.

When the evening comes, the drovers find their camp pitched and a meal ready for them, but their day's work is by no means over. The cattle are rounded up, and after a feed may settle down quietly, many of them lying down and chewing the cud. Then some of the drovers "turn in," but the mob must be watched all night. Those dark Australian nights are still and silent. In the clear sky above, now a dark violet blue, myriads of stars blaze whitely, affording the watchers just enough light to see the dark forms of the ruminating beasts. Suddenly one of the drovers 
notices a movement among them, as, startled by something vague and unascertainable, a dozen of the animals blunder to their feet. In a very few moments, the terror has been communicated to the whole mob, and, with a bellow of fright, the ringleaders dash away. The men rush for their horses, giving their sleeping mates warning of the danger, and by the time the mob is on the move, the cattlemen are spurring their horses after them. A wild ride in the dark night begins, when man and horse dash through the gaps in the mass of terrified beasts and do their utmost to reach the head of the flying mob. Should a horse happen to stumble and fall, neither he nor his rider may hope to rise again from under the hoofs of the maddened beasts behind them. There is only one hope of checking the stampede, and that is to force through the press and face the leaders with the stinging stock-whip. Already one or two of the best-mounted and most experienced drovers are in the front ranks, and the great whips are lashing the faces of the foremost beasts, checking them and throwing them back upon those behind them. The speed of the mob is slackened, and more drovers fight their way through to the front. The bullocks are suddenly brought to a standstill, and with lowered heads and heaving sides, they circle round and round as though considering how they may again break away. An unsuccessful attempt or two in this direction complete their subjugation, and the mob goes meekly back to its 


\section{The Never-Never Land}

camping-place, all the more manageable for the experience.

The Western plains, bare and dusty a few months before, are now knee deep in waving grass and trefoil, and day after day the drovers press their mob forward, ever southward and eastward. Long days in the saddle and still nights of vigil beneath the moon and stars: the life is exacting, but it has its share of excitement or of pleasure. Henry Lawson, the-Australian poet, describes it in one vigorous stanza:

The drovers of the great stock routes The strange Gulf country know, Where, travelling from the Southern droughts, The big lean bullocks go; And, camped by night, where plains lie wide Like some old ocean's bed, The watchmen in the starlight ride Round fifteen hundred head.

In time, they reach more settled country, and the farthest terminus of the longest railway line. Then the mob breaks up, some being trucked away to the big cities on the coast, and some going to the refrigerating works to be turned into chilled beef or extract of meat. The Australian city dweller, whose business or pleasure takes him out into the streets in those quiet hours of the morning when the blackness of night is just turning to grey, may sometimes see the mob of cattle on the last stage of its long journey. It is 
a strange sight for city streets: the wild-eyed bullocks, terrified by their novel surroundings, rushing down the empty thoroughfares, with the dusty stockmen on their patient horses, watcliful as ever, riding behind. A few days later, the same stockmen, brown-faced and steadfast of gaze, may be seen in the city theatres and restaurants, or out on the race-course. But a week or two of the city is quite enough for them, and they return to the Western plains with the newest songs stored in their memories to cheer the long hours of vigil round the camp-fires.

Along the stock routes, too, may be encountered large flocks of placid sheep, slowly but surely making their way across the continent. Each day sees the men in charge of them only a few miles nearer their destination, and on arriving at an area of good country, after travelling where pasture is scanty, the sheep have to be spelled for some days to recover their lost condition. A whole year may elapse during one of these long journeys, for the drover's route sometimes leads from one edge of the continent to the other. Fewer men are required for droving sheep than for cattle, and the sagacious sheep-dogs save the anxiety of watchfulness, which is part of the cattleman's life. The drover usually rides on horseback behind his flock of sheep, aithough, of late years, cycling drovers may occasionally be encountered. There are other wayfarers in these Australian solitudes. A cloud of dust marks the 


\section{The Never-Never Land}

progress of three bullock waggons, laden with bales of wool, each drawn by a long team of sixteen or eighteen bullocks. Beside each team walks the bullock driver, armed with a longhandled whip, but he relies less upon this than upon word of mouth for the direction of his stubborn team. The Australian theory, that bullocks cannot be driven without the use of the most violent and sulphurous language at the command of the driver, is cherished, I believe, in other parts of the world as well. The theory may be a fallacious one, but the amateur who has once attempted to drive a team of bullocks will usually admit that any man who can control them, even by the use of language that would under other circumstances stamp him as a blackguard, is entitled to something more than mere excuse. He should be considered worthy of admiration at least, for the driving of bullocks is an accomplishment that few may attain, however gifted of speech they may be. The bullock driver, like the poet, is born and not made.

But in the Never-Never country, neither bullock nor horse teams can compare with the camel for usefulness, and during the decade of dry years, which concluded in 1903, the "Hooshta-man" has largely supplanted both bullocks and teamster in the arid West. The camel-train is both cheaper and more expeditious. According to an Australian pastoral paper, published in 1902, the cost of transport by camel was but little more than half 
that demanded by the teamsters, while delivery was effected in one half the time. A train of fifty camels with Orieiital drivers provides a spectacle more frequently associated with the oldest civilisation than with the youngest. Yet on the sandy plains of the interior, under the cloudless skies and burning Australian sun, it possesses nothing of the incongruous. The ungainly beasts sway along, each secured to its immediate neighbour by a noose cord, which serves to keep the train in line. The foremost camel of all, usually the hand. somest and most serviceable beast in the train, is gay with gorgeous trappings of silk, decorated with swinging tassels and glittering coins and shells. Perched on his back sits the Afghan driver, in his blue coat and spacious white trousers and crowned with a huge red turban. Every camel has its load: sometimes a bale of wool on either side, or it may be the cumbrous parts of an instalment of machinery for some gold mine far away in the solitudes; while with every train may be found several animals burdened with small iron tanks of water. The camels themselves will go without water for five or six days, but when it is obtainable will drink a surprising quantity of the fluid without appearing to satisfy their thirst. The camel is a welcome adjunct to desert Australia, but the Australians take exception to the Afghan drivers for many reasons. Up to the present, however, it has not been made clear that the white man is able to manage a train 


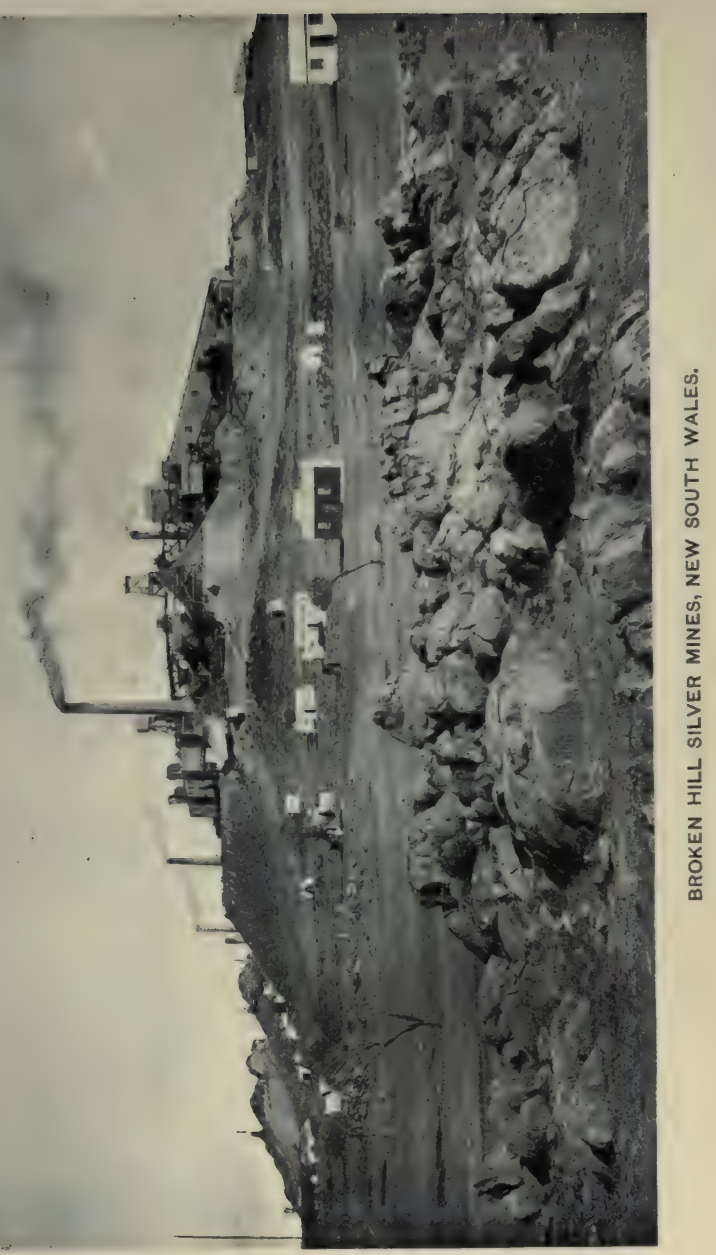





\section{The Never-Never Land}

of sour-tempered camels, the animals apparently finding some distinction between the light skins and dark in favour of the latter. Therefore the man who cries "Hooshta" in the wilderness is usually an alien, which is quite enough to make the average Australian prejudiced against the camel and all his surroundings.

The introduction of the camel into Australia was due to some of the more ambitious exploring ventures in the middle of the last-century, and the finest and most serviceable camels to be seen are the descendants from this stock. Their worth was so fully proved during the early days of the Western Australian goldfields that many animals were imported with their drivers from India and Afghanistan, but they have not proved so tractable and useful as the stock reared in Australia.

In the Australian interior occur those salt lakes that, for the greater part of the year, are lakes only in name and appearance. Seen from a distance, they are vast sheets of shimmering water, dotted with islands robed in the freshest green. A closer examination shows them to be only lake beds coated with a glittering saline incrustation, while the fair prospect of island and green forest disappears. Everywhere in this region, water may be obtained by digging, but it is as salt as the sea, or at least so brackish as to be quite undrinkable. Not very long ago, as time is counted in the history of the universe, this land was the ocean bed, and now when the rays of the sun light 
these great sand basins, the whiteness of the salt turns to a shimmering silver, and from a distance it seems as though the sea were still there-silent, misty, and boundless. The explorers tell tales of strange mirages of ships under full sail, but inverted so that the tip of the masts met the mast tips of a lower ship, apparently the reflection in the water of the topmost one. Between these salt lakes are sand hummocks, where the stiff spinifex grass grows, in spite of the aridity and saltness of the soil.

The past twelve years have seen the Australian losing ground in the Never-Never Land. Runs have been abandoned, and the discomfited or ruined run-holder has retreated nearer the coast. "There is now less of settled Australia than there was twenty years ago," wrote a mournful Australian, "for the drought has driven in many of the men who had gone out back." But at the end of the year 1902 came the break-up of the drought. Lakes that have been dry for ten years now hold ten feet of water, and creeks are running that have season after season been choked with dust. The past of Australia points to the fact that a cycle of good seasons is at hand, when flocks and herds will double themselves in one year and repeat the process the next, while there is abundance of rich pasture for all. Then, gaining confidence, the adventurers will return one by one to the alluring back country, richer for the experience of the past. Already the enterprising 


\section{The Never-Never Land}

Australians are planning to pierce it with a railway from east to west, and with another from south to north. They may be driven back for a time, but they will never rest until the last secret it holds is wrested from the Never-Never country.

Meanwhile, it is there, and supplies the element of mystery and the touch of imagination to the life of a people that is, in the main, essentially practical and utilitarian. The city clerk, hurrying to his work through the crowded streets, feels on his face the fierce north wind that has blown over a thousand miles of arid sand, and is reminded of the solitude and the great emptiness of the desert on the fringe of which he lives. The selector's wife, shading her eyes from the sun just setting over the western ranges, pictures her absent husband toiling behind the slow-moving sheep across the level plains far away beyond the ranges. The bushmen themselves tell wonderful stories of the treasure hidden away in the far solitudes "where the pelican builds her nest," and it inspires the poets and writers with something of its own mystery and strange beauty. "The wind," writes one, "comes to you over the great uninhabited spaces, desolate grey distances, and you feel somehow or other that it would have a better story to tell, and a sweeter and more familiar appeal to your heart, if it had the human note in it, if its sounds were lightened with a laugh or saddened with a sigh. . . . All Australia in its waste places is waiting for live 
men with the fire of life in them, and a power of hand and brain to translate what is barren and unlovely into something that shall be of use to man, and beautiful as his desire."

There, in a word, is the problem that remains to be solved by the great Australian statesman. It is a continent of three million square miles, and contains less than four million people, and yet the history of recent years shows how few immigrants are arriving to fill the empty places. For more than ten years, immigration has been at a standstill, while the surplus millions of the Old World have been pouring into America and Africa. Recognising this, the politicians are, at least, abandoning their cry of "Australia for the Australians," and are casting about for means whereby they may provide Australians for Australia.

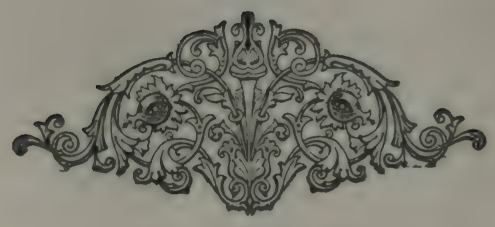




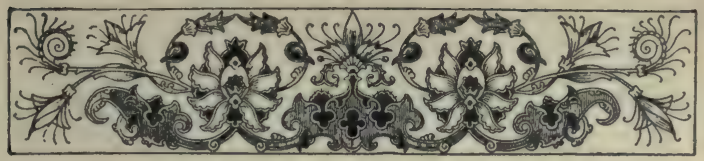

\section{CHAPTER VI}

ON THE WALLABY TRACK

“

AM not ashamed to confess that I have had to carry my swag in my time," declared an Australian Premier not very long ago. Hundreds of men occupying positions of wealth and influence in Australia could truthfully make the same avowal, for upon the wallaby track, as upon the high seas, may be found men of all sorts and conditions. Long ago, an Australian public man defined the swagman as one who goes about looking for work, and praying devoutly that he may never find it. The epigram has, to a certain extent, passed into a tradition, although it is manifestly unjust to all but a very small proportion of the men who carry their swags through the Australian bush.

The existence of the swagman proclaims nothing so loudly as the uncertainty and precarious nature of pastoral employment in Australia. If there is one thing upon which the farmer and pastoralist can rely, it is a regular supply of competent men for the busy time of shearing, lambmarking, drafting, and harvesting. There is no 
difficulty in obtaining the extra labour required at these seasons, and no question of paying railway fares or incurring any unnecessary expense. In any district where there is a prospect of obtaining such work, the man with the swag may be found, and he is usually a capable and experienced labourer. If he is not, his prospect of obtaining work, or of keeping it should he obtain it, is a very slight one. The system so far as it has been outlined is absolutely a convenient one for the pastoralist, who is able to pick and choose among the many men who continually apply for work, and to replace an incompetent man at a day's notice with one thoroughly up to his work. But the system has engendered an unwritten bush law, which entails a considerable expense upon the station-owners, and probably is responsible for much of the obloquy which has been heaped upon the "swaggie."

The law in question, the observance of which has become one of the standing grievances of the pastoralist, is that every swagman asking for work shall at least be given food enough to carry him on to the next station. It need hardly be said that the hospitality extended to the man with the swag varies in degree and in kind. Some station-owners decline to observe the rule at all, and advertise that all applications for work must be made to their accredited agent in some neighbouring township. Others expect some work to be performea in return, such as the cutting of 


\section{On the Wallaby Track}

firewood or the carrying of water. Others give a ration of flour and of uncooked meat, while the few adhere to the old order of things by providing a hut for the men's accommodation, and tea and sugar and even tobacco as well as flour and meat. The station-owners whose treatment of the swagman is based on so liberal a scale argue that the expense is justified in many ways. On their runs, lighted matches are not likely to be dropped in the dry grass, gates are not left open, nor fences broken down, and in many other ways the friendly feeling of the swagman saves them from annoyance and loss.

There is, of course, a class which abuses this hospitality, loafing from station to station and sponging upon all who will encourage them. Many of these "sundowners" have a regular round, and show some ingenuity in evading the danger of work; but the normal condition of the pastoral districts does not encourage their existence. In Australia, the natural habitat of the professional idler at the present day is in one of the big cities, and the sundowner, as a rule, is a survival or a tradition of a past era.

The man in search of work in the bush has his own title for himself and for others similarly situated. He may be a man of some substance, who rides a good horse, and leads another on which are packed all the necessities for travel. He may strap his heavy swag to the handle-bars of a bicycle, and hanging his other impedimenta 
picturesquely on the frame of the machine, plug earuestly over the dusty roads and rugged tracks of the back country. Or he may sling "bluey" over his shoulders, and with waterbag in one hand and billy-can in the other, tramp steadfastly along the wallaby tracks with a trusted mate. In any case, he is a "traveller," and does not care to be referred to by any other term.

Among travellers, the man who rides his own horse enjoys a deserved prestige. His application for work is likely to receive first consideration from managers and owners of stations. When he wishes to replenish his "tucker-bag," he can usually approach the station store-keeper with money in his hand; for he is careful to preserve his status. From the tucker-bag, a sort of pillowslip with the mouth in the middle, which is slung across the front of the saddle so that a bulging end hangs down on either side, he gets his bushname of "bag-man." The bag-man, who is generally a shearer first and a handy-man when shearing is over, probably has a round of stations where he can rely upon a pen at shearing time, as well as station work of other kinds.

The old order of bushmen still affect to look down upon the bush cyclist as an innovation and a destroyer of time-honoured' customs and practices. There can be no doubt of the genuine utility of the bicycle to the bushman, who contrives to cover immense distances on his machine, and to carry with him a quantity of luggage that 


\section{On the Wallaby Track}

would probably surprise the city cyclist. It is on record that one of these men rode seven hundred miles in eleven days on a bicycle which, with the belongings he had fastened upon it, weighed more than a hundred pounds. No bush track is too rough for the shearer cyclist, and the impromptu repairs sometimes effected in an emergency, if somewhat unorthodox, nevertheless bear testimony to the ingenuity and versatility of the Australian bushman.

But the real hero of the wallaby track is the footman, who, with his swag slung over his shoulder and his billy in his hand, tramps from one edge of the continent to the other with a patient courage that is not always recognised. The man who can camp with a couple of these travellers, sharing their billy of tea and halving with them his plug of tobacco, may go away enriched by many a story grimly humorous or charged with valuable human experience. The man with the swag faces the hardship of his life with a brave jest, as the very argot of the wallaby track will testify. He declares, with a rueful look at his swag, that he is "waltzing with Matilda," calling up by the quaint simile a latghable vision of some heavy-footed bush girl unskilled in the dance. The rags that serve him for socks are "Prince Alberts"; he lodges each night in "the Moon and Stars Hotel, ground floor." He illustrates the uneventfulness of his life and the taciturnity it induces by a story which may be heard 
in some form or other in any part of Australia, and has been christened "The Great Australian Joke." One variant of it runs as follows:

Two mates, Bill and Jim, were carrying their swags through a very inhospitable stretch of country, and both were completely down on their luck. One afternoon they passed a dry waterhole, on the edge of which was the not unusual adornment of a dead beast. When they had left it some distance behind them, Bill opened his mouth for the first time that day, saying, "Jim, did you see that dead bullock?" About dusk, they came to a creek, where they camped, lighted a fire, and made a damper and a billy of tea. A couple of pipes were smoked, and as blankets were being unrolled, Jim also spoke, saying, "It was n't a bullock, it was a horse." When the sun rose next day, a scorching hot wind was blowing, but the travellers had to push on, for the tucker-bags were nearly empty and they were in a bad country. As the sun grew more and more powerful, they felt the necessity for camping and a rest, but they came to no water, and must needs tramp wearily on. Suddenly Bill threw his swag angrily on the ground, and turning fiercely upon Jim, spoke yet again, saying, "There's too much blessed argument about this outfit for me."

The philosophy learned upon the wallaby track teaches those who walk it to mock at their own misfortunes, and to meet privation, hardship, and danger with a jest upon their lips. The traveller 
sets out on a long journey with an equipment that, at the first glance, would appear to be ludicrously inadequate. When unrolled, his swag consists of nothing more than a pair of coarse blue blankets, a few spare garments, and some odds and ends, hardly worth the trouble of carrying. With a few shillings in his pocket, to be husbanded most economically, and enough flour, tea, and sugar to last him a week, he is ready for the track.

Of course, the experienced traveller is master of all sorts of devices to make life on the track more bearable. There is an art in the very rolling of the swag, and in the adjustment of the straps which secure the ends to that which forms the loop through which the arm is passed, which materially lessens the weight of the swagman's burden. It requires experience to make a light and palatable damper, just of the right thickness, and neither doughy nor hardbaked, and the compounding of billy tea has been reduced to a science, upon which lengthy essays have been written. The billy-can, a tin pot with a wire handle across the top, and usually fitted with a lid, is the swagman's only cooking utensil. He may carry two, one fitting inside the other, the larger one being used for boiling meat, while the smaller one is at once kettle and teapot. The praises of billy tea have been sung by all who have picnicked in the bush, its excellence being probably due to the infusion of the tea leaves at 
the very moment when the water is beginning to boil. At this critical juncture, the bushman throws in a handful of cheap tea, and a good allowance of moist brown sugar, stirring vigorously with a twig of eucalyptus. The billy is then set aside for a moment while the tea leaves settle, and the brew is drunk scalding hot from quart pots known as "pannikins."

It sometimes happens that a number of travellers meet at a favourite camping-place, when a billy-boiling contest may ensue. Many bushmen are proud of the possession of a billy that is a quick boiler, that is, old and worn thin, but kept free from any coating of non-conducting soot. But billy-boiling contests usually resolve themselves into questions of individual skill in the management of a camp-fire. In the great tragedy of the bush, the billy-can also plays its part, for when the traveller has turned by mistake along the lonely track that leads nowhere, and finds himself without water or food in the heart of a pathless waste, he scratches his dying message upon the billy-can. Sometimes it is his name, or a few words that tell the whole story of the tragedy, which is still so usual an event in the "back country" as to pass almost without comment.

There are other signs which distinguish the experienced "traveller," in addition to his workmanlike swag and the deftness with which he provides for his own comfort in camp. He gen- 


\section{On the Wallaby Track}

erally knows the country well; possesses a ready tact in dealing with station-owners, managers, store-keepers, and cooks, which ensures full tucker-bags; and adds to his fare by considerable skill in fishing and trapping. He also knows where work is likely to be obtained, and it must be said for him that, having once gained employment, he is as industrious and versatile a labourer as could be found anywhere on the face of the earth. Shearing, fencing, tank-digging, horsebreaking, and a score of other accomplishments are at the tips of his fingers, and yet this handyman of the bush can only expect partial employment. Few swagmen are in work for more than six months out of the twelve.

His real weakness is disclosed when the work is over, and with a good cheque in his pocket, he once more rolls his swag and turns his face to the east and home. He knows by past experience that his only chance of making that fresh start in life of which he so often talks is to keep his cheque intact until he reaches his destination. But the bush public-house, with the grinning, obsequious landlord, and the girl smirking behind the bar, proves an irresistible attraction. Just a drink or so resolves itself into a day's steady soaking. The cheque passes into the keeping of the landlord, and when the bushman finally regains sobriety, after a week's steady spreeing, it is only to learn that he has spent all his earnings except a very small balance. With curses upon 
his own folly, and many resolves not to repeat the experience next time, he once more faces the wallaby track, and the heart-breaking search for work which is so difficult to obtain.

It may be that if it were not for the bush shanty and the bad liquor sold in it, the number of travellers on the Australian bush tracks would be lessened by more than half, and the pastoralist, instead of complaining of the drain upon his stores, would grumble at the scarcity of experienced labour. The steady swagman usually becomes a selector in time, and marries and settles down in his own bush home. The failure of his crops may drive him out upon the tracks again, to knock together a cheque while his wife looks after the home and the stock. That, however, is only a temporary expedient, and after the shearing or the fencing contract is over, he will return to his clearing with money in his pocket and hopeful for better seasons. Some of the neatest and most prosperous little homesteads in the Australian agricultural districts have been won by men who began with a cheque earned while they were carrying their swags in the "back country."

It is the drinking, improvident man who carries the swag all through his life, and ends on some wholly forgotten track with the crows blackening the trees above him. The hardships of the life, and the constant exposure to weather of all kinds, must have their effect even upon the hardiest constitutions, and the excesses indulged in play their 


\section{On the Wallaby Track}

part in wrecking the swagman's health. Many end their days in the country hospitals, which are so largely supported by collections taken up at every shearing-shed, and to which the swagman has usually contributed generously at some time in his career. Even the old age pension, which the needy who are past work can obtain in some of the Australian States, is not for the swagman, whose wanderings from state to state deprive him of the right to claim this dole.

In spite of the hardships and disadvantages of the life, however, the swagman may be found on every road and track in Australia. $\mathrm{He}$ is an object of suspicion, and liable at any moment to find himself accused of some crime of which he may not even have heard. He is accounted the cause of all bush fires, and is judged by the worst specimens of his class and not by the average. And yet, having once learned the fascination of the open road, it never loses its charm for him. I have an old friend, settled now in a pleasant town on the Victorian coast, with money in the bank, won by him on the Western Australian goldfields. To use his own term, he is "an independent man." But when spring comes, and old Ben gets a whiff of the bursting wattle, the call of the open road proves irresistible. He says he must go and have a look at the country, and accordingly greases his bluchers and rolls his swag, and with a whistle to his dog, is off afoot. A month later, he comes back looking younger, and full of bush tidings. 
Some "chaps" have bottomed on good wash dirt over the range from Lonely Gully, where he had always said the indications were favourable. An old crony in the Wimmera district has just put in another acre of vines, and complained that the parrots, worse than ever this year, have not left him a single cherry. The farmers in the Mailee are complaining of the locusts already, and he (Ben) would like to know whether the Government ever will do anything about it; and so on, with many a yarn of bird and beast observed by the way, of bush publicans, civil and uncivil, and of "chaps" hard-up or humping their swag in deadly earnest. Old Ben likes it all. May he live many a long year to carry his swag through the glad bush in the first joyous flush of spring!

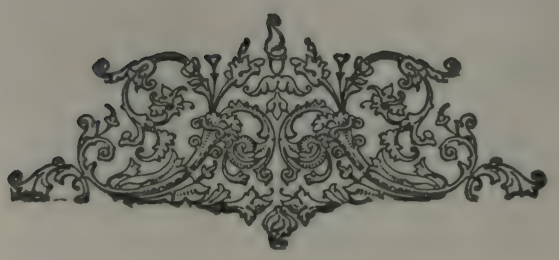




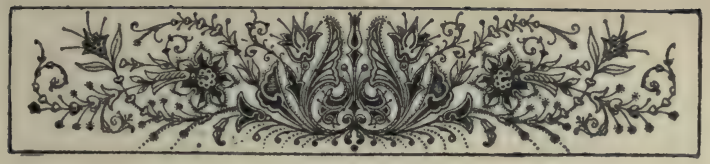

\section{CHAPTER VII}

\section{IN TIME OF DROUGH'T}

THE prosperity of pastoral Australia depends 1 upon the rainfall, and as the dying autumn ushers in the rainy season, the squatter waits with anxiety for the first signs of the change of seasons. The average annual rainfall of the greater part of pastoral Australia is no more than twenty inches, although in some districts a much greater amount of moisture may be expected. When the long-expected rains come, there is a succession of heavy, drenching showers, which fill the lagoons and water-holes, and convert the trickling creek beds and dry water-courses into foaming yellow rivers. Afterwards comes the sun, causing the grass to shoot up bravely, and every shrub and herb to sprout vigorously, covering the whole face of the land in a mantle of smiling green.

Should the season prove an exceptionally favourable one, the showers are repeated at intervals during the winter and early spring, and the pastoralist sees the wattles bloom with the 
happy certainty of a good year. Summer suns and scorching hot winds may parch every vestige of grass from the face of the land, but that he accepts as a matter of course. The stock will live through it all, and prosper and multiply in a manner quite astounding.

Sometimes these good seasons follow one another in succession, or are broken only by a year when the autumn rains are light and unsatisfactory, and the summer sees an uuwelcome scarcity of water. The history of pastoral Australia points to the fact that just as these good seasons have moved in cycles, so have they been followed by a succession of lean years, terminating in a drought during which the grass has never sprouted, and the edible shrubs have been eaten down to the very root by the starving stock. In times such as these, want of food and want of water have caused terrible mortality among the flocks and herds of the Commonwealth.

In I89I, there were one hundred and twentyfour million sheep in Australia. Then came a long series of dry years, culminating in the exceptionally bad ones of 1901 and 1902 , by which time the flocks had shrunk to less than half that number. These figures are more eloquent of the terrible animal suffering endured than any written words could be. They mean financial loss, too, and ruined hopes, and the abandonment of homes created by the unflagging toil of a lifetime. Here is a brief story, chosen from among a num- 


\section{In Time of Drought}

ber told in the Australian newspapers concerning the havoc wrought by drought:

Ridley Williams had occupied Burbank Station for thirty years. In the 'eighties, he thought he was a rich man, for three thousand calves were being branded each year. Then came the bad seasons, and in 1902, only two calves were branded. Just then the rains came, and the grass sprang as it had not done for years. He looked round and reflected that it might come right after all. But he considered it was only annual grass and light herbage, that the old drought-resisting plants were gone. He counted the cost of restocking, he counted the risk; then, plucking up courage, he packed his portmanteau, sent on what few head of stock were left, and abandoned Burbank, "improvements and all."

That is the story so far as it goes. The sequel occurs readily enough to the imagination. Into the run abandoned by this pioneer, another will surely step, perhaps to be favoured by good seasons and to achieve a rapid prosperity. Or perhaps he will but repeat the experience of his predecessor; for judgment, industry, and business ability count for nothing against the fickle climate of Australia.

One day from the life of drought-stricken Australia will serve to describe the terrible struggle with nature that is carried on through so many bitter years. Sunrise comes with a fiery red glow and a scorching wind, so dry and blasting that it 
seems to come from some white-hot furnace. After a hasty breakfast, washed down by scalding, milkless tea, the pastoralist throws himself into the saddle, and rides away to the big station tanks to superintend the work already going on there. Round the shrunken pool of yellow water stands a row of sheep, unable from sheer weakness to extricate themselves from the mud into which they have rushed in their eagerness to drink. Some are already dead, while men are busily employed in drawing the survivors from the trap into which they have fallen. Their owner looks at the pathetic, bleating animals, mere skeletons covered by wool and hide, with a dull wonder that they have lived so long, and a dead certainty that they cannot live much longer.

$\mathrm{He}$ rides on. On all sides are skeletons and decaying carcasses, with gorged crows flapping lazily away before him. Not a blade of grass to be seen anywhere, nothing but the scanty black green foliage of the gums, and in the distance the grey, dusty mulga scrub. He heads for the scrub, crossing the creek-bed, now dry and choked with dust. Men are cutting down the mulga, the only food the station now affords to the starving sheep. It is the last resort, and the animals eat it: not eagerly, even though they be starving, for it is tough and uninviting.

His next visit is paid to his stud flock, once the pride of the station, and still cherished with care, for it represents the only hope for the future. 


\section{In Time of Drought}

From a deep water-hole, a man is pumping water into troughs, while another is opening bags of chaff and spreading their contents about mangers of hessian, stretched across upright saplings. This is hand-feeding, and an expensive business, for the chaff has to be brought many hundreds of miles by boat and train, and last of all by team or camel-train. Each sheep costs him sixpence a week to feed, but as long as he is able to provide or to borrow the money, it must go on. There is nothing else to do.

The sun climbs higher in the heavens, and the feeble sheep creep listlessly into the shade of the gum trees. Some of the men set about removing the hides and wool of those that have recently died. Everything seems at its last gasp, and the choking wind sweeps across the sun-baked land, smothering everything with dust and grit. The very air is foul with the thousands of decaying carcasses lying around. Weary and dispirited, the owner of this desolation turns his jaded horse back to the homestead, to receive what sympathy and comfort his careworn wife is able to give him.

The sufferings of the domestic animals in drought time are shared by the wild birds and animals of Australia, until these are forced to lay aside their timidity by want of water and food. At such times, it is interesting to camp by a water-hole and observe the wild things as they come to drink. With the very first streak of dawn comes a mob of kangaroos, betraying their 
arrival, as they hop along, by the thud of their great tails. After them come birds: parrots of all kinds, gorgeous in green and blue and scarlet; screaming cockatoos, all gleaming white, or modest in pink and grey; magpies, kookaburras, crows, and doves in hundreds, with countless smaller birds. Screaming and chattering, they fly away as a drove of scudding emus reaches the edge of the water, peering suspiciously on this side and on that before lowering their heads to the water. The imported rabbit is everywhere, and makes a good fight against the drought, as against every means devised for his destruction. But before the sun is well up, the wild animals have taken their toll of the water-holes, and the procession of sheep, cattle, and horses begins to arrive. It is only in very severe years that the wild birds and animals die by reason of the drought, but that occurred in 1902 . It was no uncommon thing in that year to find birds dead of starvation, for, although these could usually procure water, the supply of insect and other food was so scanty that they haunted the camps of men, on the look-out for scraps of food. In 1903, an Act was passed by the Parliament of New South Wales making the destruction of kangaroos, opossums, and other wild animals illegal for some years, the reason being that, owing to the drought, these animals had become so scarce that their total extermination seemed imminent. The last effect of this great drought was the destruc- 


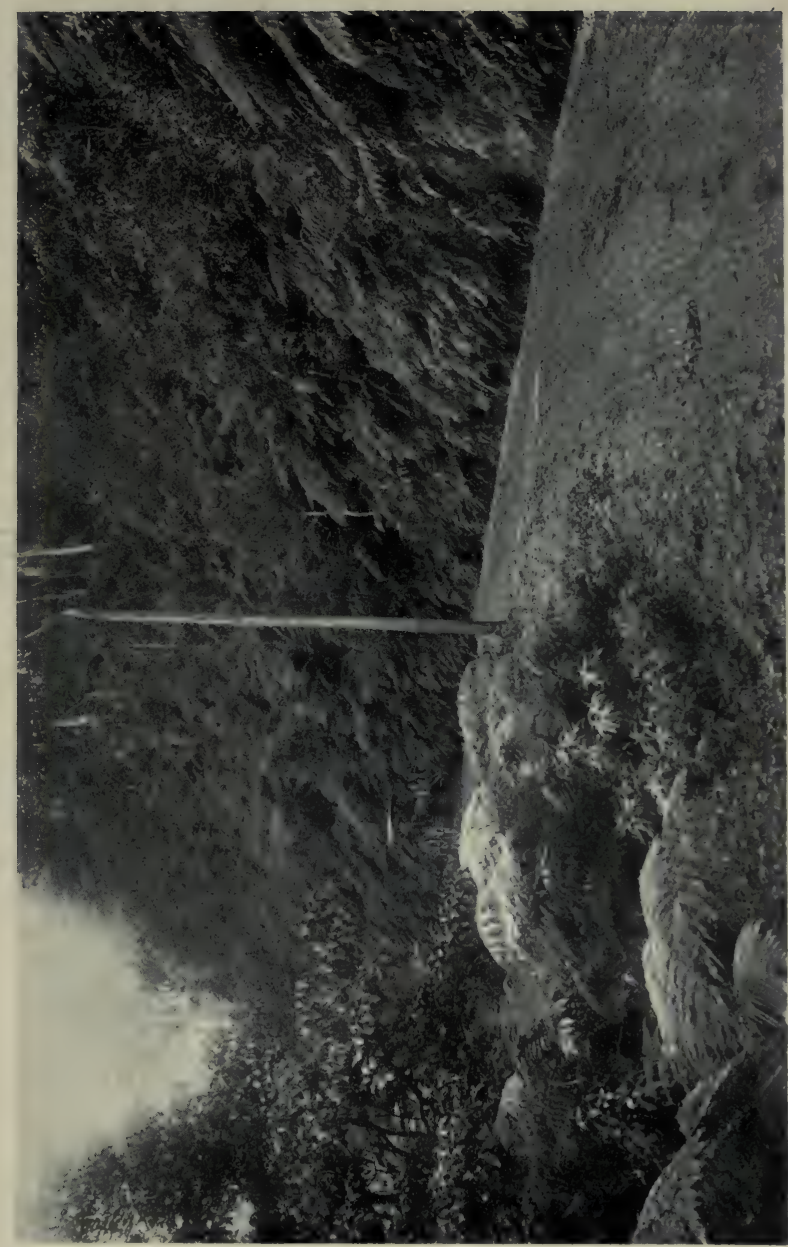

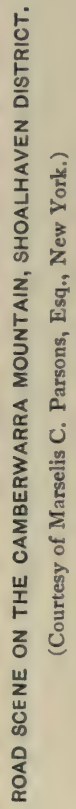





\section{In Time of Drought}

tion of areas of forest, the deep-rooted Australian trees actually perishing for want of moisture. Never before in the records of the history of the continent had the effects of the drought been so far-reaching.

Such an experience, quite without precedent during the white man's occupation of Australia, has not been without the educational effect. The Australian pastoralist has learned, from bitter experience, a great deal about fighting the drought that was not previously known. Experiments made with native shrubs and trees have proved that many of these are of considerable value as fodder plants when all else fails. Among the plants so used was the despised prickly pear, the fleshy leaves being boiled and used as fodder, and serving to keep much valuable stock from absolute starvation. In the same way, the hungry stock learned to devour the bulbous trunks of the Australian bottle-tree and the leaves and twigs of a forest tree known as the kurragong.

These, however, were the expedients resorted to in desperation. The more valuable lesson gained from the drought was the necessity for caring for and propagating the priceless droughtresisting shrubs, such as the saltbush, which are natural to the saline lowlands of the interior. Transplanted to California, the value of the saltbush was at once recognised there, and measures for its scientific propagation were taken with the most successful results. From this example, and 
from the lessons of the lean years, the Australian pastoralist has so far profited that considerable attention is being devoted to the spread of this plant and others of a kindred nature.

Provision for the storage of the water that falls during the rainy season has always been of a primitive nature, for the great evaporation which takes place under the summer sun discouraged any elaborate precautions of this kind. Nevertheless, the importance of conserving, as far as possible, the plentiful supplies that invariably run to waste in the rainy season is now more fully recognised than it has ever been. Plans for locking the more important of the rivers and creeks have been from time to time proposed, and practical steps are now being taken to carry into effect the more feasible of these schemes. The conservation of large supplies of water during good seasons would appear the most obvious precaution against the dry years that must inevitably follow, as experience has shown; but, in the past, a good season has been a sort of fool's paradise, during which the pastoralists have idly watched the valuable water running away to waste.

The improvidence of Australians in this respect is made strongly apparent by such a curious spectacle as was witnessed in a little town in the western district of New South Wales when the great drought broke up in 1903. For many months, the inhabitants had been supplied with water carted from a distance, although a dry 


\section{In Time of Drought}

stream-bed choked with dust, and a wooden bridge spanning it, bore witness that under normal conditions the settlement could boast of a river. The breaking of the drought was heralded by news of heavy rains nearer the coast, and by the rumour that a head of water was actually rushing down the upper reaches of the river. This rumour was confirmed by an excited horseman, who rode into the town one breathless evening, yelling that "she was coming down." Everybody turned out to witness the sight, lining the banks of the dry stream-bed and gazing up the empty channel with anxious eyes. The coming of the water could be heard before it was actually in sight, a hoarse whispering as the advancing flood licked around the sun-baked stones, and stirred among the dead twigs and grasses. Then an inky pool appeared in the stream-bed, now stationary and now moving quickly forward. It broadened as it trickled through the little town. Behind it came a rush of yellow waters, laden with débris of all kinds, filling up the hollows and washing away the year's accumulation of dust or grit. Two hours later, the dry creekbed was a roaring torrent, and the excited man borrowed a fresh horse to convey the glad news to townships further down the creek.

Most of that water ran uselessly away from the places where it was wanted, just as it had for ages past in parched, unthrifty Australia. It would be strange indeed if the waste of it did not appeal to 
the drought-stricken bushmen, and if the necessity for storage works were not recognised as a matter of national importance. Unfortunately the capital required for the construction of the necessary storage areas is not at present forthcoming, and the work of irrigating Australia is progressing but slowly. It is obvious, however, that the conservation of water, even if carried out on the most extensive scale, will not cause the grass to grow in years when there is no rainfall. The loss of stock is caused by want of food, and no scheme of water conservation would be adequate for the irrigation of the vast grazing areas of Australia. Water conservation can only be part of a system which will include the growth of large crops of green fodder by means of irrigation, and the preservation of this fodder in silo pits. The many experiments made in this direction have generally proved successful, the favourite fodder plants being maize, lucerne, and varieties of sorghum. Like most arid countries, Australia possesses a soil capable of producing remarkable crops when irrigated, and the growth of luxuriant fodder plants is only a question of the proper application of water. It may confidently be predicted that the next development of pastoral enterprise will be the storage of water, and of large supplies of fodder, in both a green and dry state.

The most satisfactory advance in the direction of providing water has been made by the utilisation of the stores of artesian water, which have 


\section{In Time of Drought}

been proved to exist under an immense area of Central Australia. This underground water supply is tapped by means of boring, and in some instances the soil has been penetrated to a depth as great as five thousand feet in order to reach the subterranean water. Very frequently the water, when tapped, spouts strongly out, although in some places it only rises to a certain height in the bore, and must be raised to the surface by means of pumps. The boring operations are conducted both by private individuals and by the government of the Australian States, some of which maintain a staff of specially trained officials for this work.

The importance of this subterranean water supply can best be illustrated by the example of one bore, sunk in a dry and waterless tract of country, which has now for years yielded a flow of water averaging six million gallons each day. At Dagworth, in Queensland, there is an artesian well from which water flows at a temperature of $196^{\circ}$ Fahrenheit, and many of the Queensland artesian wells discharge water of a temperature exceeding $100^{\circ}$ Fahrenheit. This artesian water has been proved as valuable for irrigation purposes as any surface supply, and when it has sufficiently cooled, the stock drink it just as readily. Boring for water is still being prosecuted with energy in all the states except Tasmania and Victoria, and from the results already obtained the pastoral districts have reaped incalculable benefit. 
Perhaps the most bitter reflection of the droughtstricken station owner arose from the knowledge that, while his stock was starving, there were large areas further east where a plentiful supply of grass was actually wasting. No means existed for transporting his stock to this supply of food, for they could not travel through the barren country that lay between. In the opinion of the president of the Queensland Pastoralists' Union, the most practical suggestion for fighting drought in the future is one for the construction of light railway lines into the western and northern pastoral districts, thus enabling stock to be removed from the drought-stricken areas.

The recovery of the Australian back country from a long succession of dry seasons, such as those which culminated in the disastrous year of 1902, is necessarily slow. The rains that break the drought cause the grass to spring up bravely, it is true, but it is a delicate growth and does not withstand the hot sun for long. The fodderplants, eaten down to the very roots in the lean years, have not had time to recover themselves, and would probably never do so were it not for the diminution of the stock upon the land. The havoc of the drought is not so easily repaired. A Bulletin writer, in a few vivid words, describes the bush in its first stage of recovery:

"A neW world, seemingly-a world of green, good to look upon, though it was of forced, unstable growth, with no vitality. The poor bush 


\section{In Time of Drought}

tries to hide its nakedness in this short-lived life, but the skeleton-bare, gaunt, blackened with fire, tortured by thirst-cannot be so quickly hidden. It is hideously apparent, and pitiful to see. Down in the gullies, on the plains, which a few months ago danced with white molten heat, now tinted soft with the crude tints of verdure, lie the white gleaming bones, sorrowful amongst the newly sprung grass. The depleted flocks drift and browse around them-menacing landmarks of the summer to come. . . . It will be a bare, bleak world for this year's lambs. The poor weakly mothers will be little protection against the cold of early spring and the devilment of the crows, who, preening themselves high in the oaks, or flapping lazily over the paddocks, are bitter forecasts of the heat-time to come."

The unstable nature of the foundation upon which the pastoral industry has been reared is shown by the fact that of the last twenty-five years of the nineteenth century only nine brought good seasons. In some of the worst years, the agricultural districts also suffered, and so severely was the drought of I9OI and 1902 felt in the wheat-growing Mallee district of Victoria, that many farmers actually left their holdings, some of them turning their backs on Australia in despair. In the Australian cities, which are largely dependent upon the prosperity of the back country, the pinch of drought causes an unwelcome tightness of money, as well as an increase in the 
price of commodities; while the large floating population of bushmen experience scarcity of work consequent upon the diminution of the flocks. It is no matter for surprise, then, that the Australian inventor sets himself seriously to the task of rain-making; or that an Australian public man declared that "a week's steady rain was worth more to Australia than all the gold mines of the West."

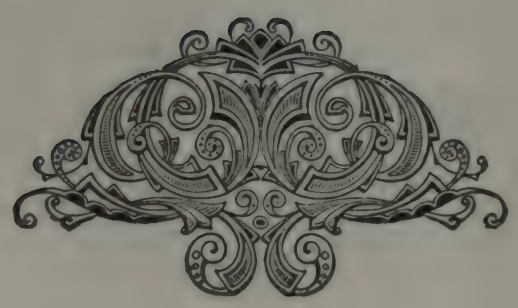




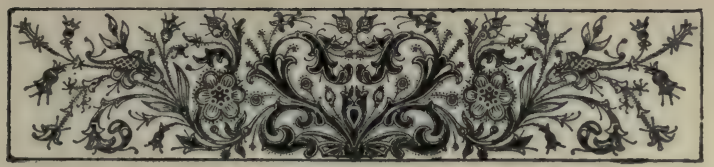

\section{CHAPTER VIII}

\section{URBAN AUSTRALIA}

THE size and importance of the Australian cities, when viewed in the light of the total population of the continent, are a source of surprise to every visitor. The population of Sydney and Melbourne may be set down, in round numbers, as half a million each, thus accounting for one million of the two and a half million inhabitants of the two most populous states. A better idea of the wealth and trade of these cities may be gained by comparing them with other cities of the Empire. In the value of ratable property, Sydney is second only to London among Empire cities, while as a seaport, Sydney takes fourth place among the ports of the Empire for the actual value of trade. Melbourne is in everything the rival of Sydney, and ranks little below that city in wealth and volume of trade.

In the other Australian States, the same characteristic is noticeable. Each can boast of a capital city where a large proportion of the state inhabitants dwell, and this proportion shows a tendency to increase rather than diminish. The 
causes which have contributed to the growth of these cities, so huge when compared to the population of the country behind them, lie in a variety of circumstances, the most important being the great trading activity of the Australian people. Each capital is the sole trade outlet of a vast and productive state, and also the channel through which the imports for the use of a prosperous and free-spending people must flow. Every railway constructed leads directly to the capital, and the capitals monopolise the trade which flows from one Australian state to another. They provide facilities that exist nowhere else in the state, and have therefore attracted to themselves the bulk of the manufactures fostered by the protective tariffs adopted by most of the Australian States. Like a snowball, they have grown by growing.

The business and the home life of the people who live in these cities can better be described when some of the leading characteristics which distinguish them have been outlined. They were all designed to be big cities, with broad straight streets and spacious public parks. All the inconveniences of older cities have been avoided; room for expansion on all sides has been provided; everything has been planned on the grand scale. Melbourne is a typical Australian city. The city proper is a mile square, every corner is an exact right angle, and every street is exactly one mile in length. From the great central railway station, any part of the city can be reached in a few 
minutes by walking, and to that station every suburb sends frequent trains. The double line of tramways running along the centre of each street leaves a way for the traffic on either side as wide as streets were made in olden cities. In his square mile of city, the Melbourne man finds everything - Houses of Parliament, town hall, post-office, museum, theatres, banks, churches, newspaper offices, Stock Exchange, restaurants, libraries, and shops. Beyond the city area, the suburbs stretch for eight miles in every direction, but the business of the city, and practically of the whole state, is transacted in that square mile of city. The public buildings are on an ambitious scale. Most of them were planned at a time when Melbourne possessed a sanguine statistician, who published a calculation showing that the population of Australia would be thirtythree millions in I95I, and one hundred and eighty-nine millions in 2001 . He based his figures on the rate at which the population was then increasing, but unfortunately that rate has not been maintained. Nevertheless, the public buildings are there in anticipation of the time when the population of Melbourne shall be as great as that of London at the present day. The front of the Parliament House is already complete, and when the dome has been added, the building will be a noble one. The governor's residence is a gigantic palace, and of the public offices, some one has unkindly written that they look as if they had been 
built by the mile. During a land boom, the price of the city land was put up to such an extravagant price that several speculators availed themselves of the presence of an American architect to erect "sky-scrapers" of twelve and fourteen stories. The liberal scale upon which banks, insurance offices, and other buildings have been erected prevents the tall buildings from looking hopelessly out of place; indeed, the city escapes the criticism of being overbuilt, because everything is in proportion. The surpassing activity of the people in this compact city area is part of the city itself. Wide as the streets are, they hardly suffice for the traffic of the vehicles that crowd them. The footpaths are also liberal of dimension, but they are always thronged in business hours. Every lamp-post bears a notice requesting that "pedestrians keep to the right," and owing to the general compliance with this request, there is no confusion between the two streams of foot-passengers that pour so rapidly through the city. The first and most lasting impression of Melbourne is a roar of traffic, a continual clanging of tram-bells, and an eager crowd, always hurrying.

It would be easy to write at length of the distinctive features of each Australian city, but it is my object rather to point out that they all possess the general characteristics I have indicated. They have a compact business area, the most modern and convenient means of travelling, and 
every facility for the rapid transaction of business. The influx of business men from the suburbs begins shortly before nine o'clock. From the big railway station issues an endless stream of human beings, as train after train arrives from the suburbs. Every train is crowded, and the ferryboats ply busily across the water. The footpaths show that the stream is setting in one direction only, towards the heart of the city. The stream continues to flow until half-past nine, and then stops. Principals and employees are all in their places by that hour, and business is in full swing. Many of the Australian business customs are practical and convenient. Some warehouses close their doors for three-quarters of an hour in the middle of the day, when it is an understood thing that members of the staff take their luncheon. During the rest of the day, every employee must be in his place for the transaction of his business. The long luncheon hour and the subsequent dragging on of business are not possible; there is not enough time. The banks shut their doors at three o'clock, and most offices at five. At six o'clock the shops put up their shutters, and every one is at home, or on the way home.

It is a short day, but it is a busy one. When they say in Australia that a man can "run like a Melbourne shipping clerk," they intend to pay tribute to his speed. The Sydney man moves in a more dignified manner, and the people of Brisbane are so leisurely, by contrast, that the 
southern states have christened Queensland " the land of lots o' time." The Brisbane man is usually sitting still or riding on a train. He wastes no effort, but the net result of his day's work is usually a satisfactory one. The principle underlying business in Australia is decision. The man who says "I 'll think it over and write to you" is a comparative rarity. The average Australian business man, if he thinks he sees a chance, is willing to take a risk, for he knows very well that the offer is not likely to be repeated. He has another characteristic. He can lock up his office at five o'clock and leave his business behind him in the office. When he leaves the city for his residential suburb, the thread of business is broken, and will not be taken up again until he steps out of the train next morning. In the meantime, he lounges, both mentally and physically.

There is nothing arbitrary in the selection of residential districts near the big Australian cities; the best situations are occupied by the best class of suburbs. The squatter whom we have seen in his Riverina station also occupies a mansion at Pott's Point, near Sydney; at Toorak, a Melbourne suburb; or in some corresponding outskirt of one of the Australian capitals. The most striking feature of the big grey house is its wide colonnaded balcony, and the extent of the grounds that surround it. There is nothing distinctive about the interior; ball-room, billiard-room, library, reception-rooms, all are arranged after the 
conventional fashion. The grounds are remarkable for their thick lawns of stiff buffalo grass, springy underfoot, but harsh and coarse to the touch. The luxuriance of foliage and flower is surprising. The long carriage-drive is bordered by great clumps of arum lilies and purple iris, with groves of glossy camellias and ornamental shrubs and trees drawn from every part of the world. Glass-houses, conservatory, and stables are arranged on a scale of luxury and convenience. From the balcony is obtained a magnificent view of the harbour and of the compact city area, bristling with spires and domes and many-storied buildings. It is a pleasant country house, in the heart of a big city.

The squatter's presence in town is due to the session of the State Legislature, for he is a member of the Upper House, or Legislative Council. The chief function of this Council is to check the Socialistic tendency of the Lower House, the members of which are elected on a basis of manhood suffrage. A class vote or a nomination secured him his seat in the Upper House, where he sits with men the majority of whom, like himself, are wealthy and have pastoral interests. His legislative duties are not exacting, and he has time to transact business with his city agents, to renew at the club his associations with his intimates, to see his horse run in the Cup, and to pick up at the stud sales a ram of some celebrated strain which costs him a thousand guineas. 
Suppose we accompany him to the city, where he has a busy day before him. He catches the train not a hundred yards from his house, and it is interesting to notice that as it approaches the city, the car passes through several zones of sub. urbs, each of a different class. Next to his own suburb is one of detached villas, each with its own garden; then comes a region of wooden cottages, all neat and comfortable; and finally, stucco terraces, rather dingy and crowded, and many of them with cards in the window, proclaiming that "board and residence" may be obtained within. Suddenly a corner is turned and the city area is reached. Alighting at a corner where two policemen are regulating the throng of traffic in a manner that recalls their London doubles, he walks rapidly down two blocks and turns into his club. Half a dozen letters have to be answered, including one from his station manager; then he must see his solicitor, and afterwards the principal of a wool-broking firm. It is now lunch-time, and he invariably lunches, when he is in town, at the same hotel. The room is a public one, and we will take our seats at one of the tables, for there are some interesting people here.

The grey-bearded man with whom our squatter has just shaken hands is editor and proprietor of a big daily paper. He plays no open part in politics, but is credited with having made and unmade each of the many Governments that have ruled the State during the last twenty years. 
Next to him sits a member of the Federal Parliament, who is still a young man. He is a partner in a big city firm, has interests in every state of A ustralia, was knighted not many years ago, and fought bitterly and successfully for the employers in the greatest strike Australia has ever known. Our friend next greets a brother squatter who is a Federal Senator and a prominent Orangeman. He has a political grievance against the Australian Premier, because of a friendly visit paid by that gentleman to the Pope on his way back to Australia from a visit to London. Nevertheless, he is chatting amicably to an Irish barrister, whom the same Pope has made a knight of St. Gregory, on account of services rendered to the Church in Australia. A university professor and the part owner of one of the richest mines in Australia complete this party of city magnates, the members of which represent almost every shade of Australian opinion. It is obvious enough that they do not carry public differences into private life. The lunch is soon over, for they are all busy men, and our squatter makes his way by tram to the building where the State Parliament meets. Under ordinary circumstances, the House will adjourn early enough to permit him to attend to his social obligations afterwards.

The solicitor whom our squatter consulted may well be taken as a type of the professional class. $\mathrm{He}$ is a rising young man, has married a relative of his wealthy client, and because he has a 


\section{4 \\ Australian Life}

taste for yachting, - an expensive hobby, it may be said,- has chosen to live in one of the outlying suburbs by the seashore. His villa faces the bay; it is his own, but a similar one could be rented for $£ 80$, or $£ 90$, a year, inclusive of all rates and taxes. To that sum must be added the cost of the season ticket for railway or boat, but for an outlay of $£$ Ioo a year a charming home can be obtained. The house is of the bungalow type, cool, roomy, and convenient, and the garden is a miracle of brightness. The attraction of the suburb is the beach. A little jetty makes a breakwater for the fleet of tiny centre-board yachts anchored in its lee, and near it is a bathing place, enclosed by a wooden palisade to keep the sharks at bay. The residents can be in the city half an hour after the train leaves their railway station, and once home again, they are in a different atmosphere, getting the first breath of the cool evening breeze at the close of the burning summer days.

Our solicitor's professional work does not take him into the courts, and has nothing to distinguish it from the practice of a similar business elsewhere. At half-past nine, he is at his office, and at one, he lunches with a few friends at an establishment that is deserving of some description. The proprietors are two young ladies, well known in society, and although they spend their days in a tearoom, they retain their circle of friends, among whom are many of their customers. 


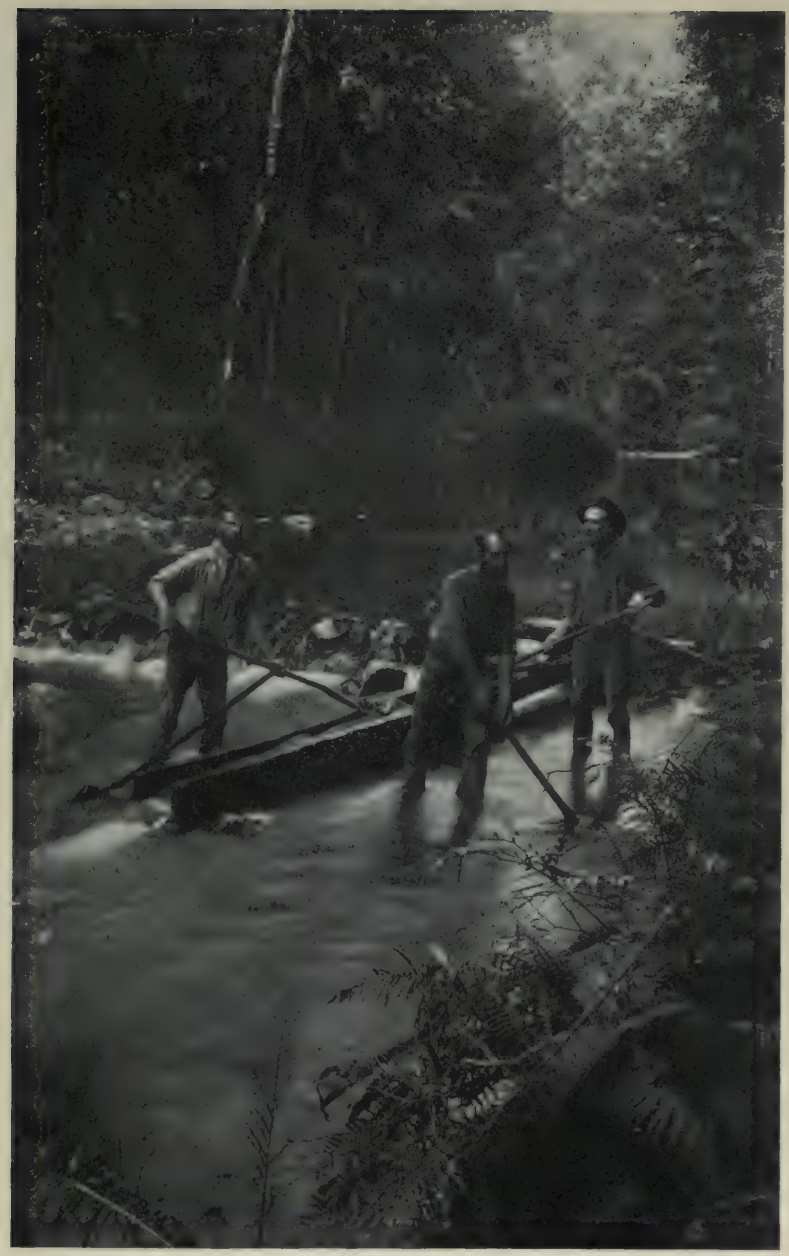

SLUICING FOR GOLD AT FRESHWATER. 

Their adoption of this business was made necessary by the financial crisis which occurred in Australia in 1893 , when many families were reduced from wealth to the poorest circumstances in the course of one disastrous week. The young ladies who attend upon the customers are educated and refined, and daintiness is a feature of the furniture and the fare. Prices are strictly reasonable, and everything supplied is the very best of its kind. Our solicitor may not improbably meet the young lady who brought him his cup of coffee, at the house of some friend, and such a meeting would certainly occasion no awkwardness on either side. About half-past four, he will catch a train home, in time for a sail in his little yacht before dinner. One or two evenings each week will probably be spent at the one club of the suburb, where there are tennis-lawns and bowling-greens, with a skittle-alley and the usual billiard and cardrooms. The members of the club all appear in easy flannels, and may be stockbrokers, civil servants of the higher grades, and young professional men like himself. The local politics of the place he leaves to the local tradespeople, and complains a good deal of the result of his own neglect. At the same time, municipal affairs will never assume any great importance in Australian cities, owing to the fact that many municipal functions are already undertaken by the state governments.

When he takes a holiday, he may choose among 
a number of desirable resorts. Perhaps the ideal holiday for an Australian is a visit to New Zealand, with a sea voyage of twelve hundred miles, and a change to a country unlike his own in every particular. Or he may journey inland and spend his vacation in the bush, which offers a round of riding, driving, and shooting. Dotted around the Australian coast are watering-places which combine the attractions of the seaside with those of the country, so that the holiday-maker may picnic in the fastnesses of the fern-tree gullies on one day, and spend the next in fishing on the schnapper-grounds of the open ocean.

It will be apparent from even this slight outline that the life of the moneyed and professional classes in an Australian capital city differs but slightly from that of the same classes in Great Britain. They have adopted a shorter and more strenuous business day, and have utilised the experience of the Old World in obviating many of the inconveniences unavoidable in the life of cities which have grown by gradual stages through a course of centuries. Convenience of travelling facilities has permitted the growth of the suburbs outwards, and so given an air of spaciousness to even the most commonplace of the residential quarters. The provisions made for parks and open spaces are liberal, and the Australian citizen takes an interest and a pride in the many public gardens and playing-grounds with which his city has been furnished. For these reasons, and be- 


\section{Urban Australia}

cause of their propinquity to the sea-coast, all these big Australian cities are healthy, and can boast a low death rate. That they continue to increase in proportion to the population of the country behind them is not due to these causes so much as to the fact that they offer to the working class such advantages as no other cities in the world can offer. The attraction that city life has for the humbler classes is evident even in the Old World, where the contrast between the conditions of town and country life is not so marked as in Australia. Here the reasons for flocking to the cities are obvious enough. To quote the Bulletin, the most powerful organ representing the opinion of the Australian working-man: "A trade, and regular work at that, made at union wages, is worth more than the average six hundred and forty acres of land available for selection in any Australian state. It is hard reasoning on a cash basis, not silly hankering after city life, that brings the young bushman to town."

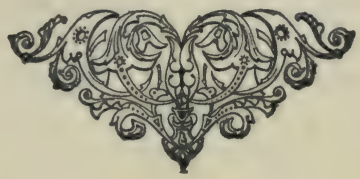




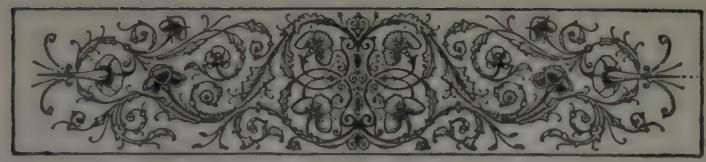

\section{CHAP'TER IX}

\section{IIFE IN THE CITIES}

USTRALIA has so often been described as
the paradise of the working-man that the phrase seems to have lost part of its meaning from constant repetition. The factors conducing to the satisfactory condition in which the Australian artisan finds himself are primarily those he has established for himself, namely short hours of labour and high wages. But these conditions apply elsewhere, and notably in the large American cities, where the working-man is, nevertheless, far from being as well off as in Australia. In the first place, the housing difficulty does not exist for the Australian workman. There is not one tenement building in all Australia, for every family can obtain a comfortable cottage at a moderate rental. A well-built house with five rooms and a bathroom, within comfortable walking distance of his work, can be got for about ten shillings a week, a sum which does not bear so high a proportion to his weekly earnings as the seven and sixpence which the British workman has to pay for two or three rooms in a gloomy I08 
tenement. A garden in front of the cottage, and a plot of ground of respectable dimensions behind it, belong as a matter of course to the Australian workman's dwelling. It has been said that the workman is able, if he wishes, to live within comfortable walking distance of his work. The tendency of the Australian middle class, is still to occupy the more distant suburbs, so that the suburbs of an Australian city nearest to the actual city area will usually be found in the occupation of the humbler classes.

But should the workman choose to rent a cottage a few miles out of the city, he is admirably served by tram and train, or by a cheap and rapid ferry-boat service. The convenience and cheapness of the State-owned suburban railway lines can only be appreciated by those who have acquired a wide experience of profit-earning railways in other lands. The Australian suburban lines, as the property of the people, are administered in the interests of the traveller rather than with the object of earning the highest possible profit. The trains are run frequently and punctually, and a special scale of fares within certain hours enables the workman to travel at an expense that is almost nominal. Thus the ten shillings a week he pays for a cottage near town will pay the rent of an even more comfortable dwelling six or seven miles away, as well as the additional cost of his railway fares. There he will have a plot of land, perhaps half an acre in 
extent, where he can gratify his tastes for gardening and poultry-keeping to the fullest extent.

The cheapness of food is another circumstance in favour of the Australian workman. He can dine, if he wishes, at a cleanly kept restaurant where a substantial meal of meat and vegetables, with pudding to follow, can be had for sixpence. A better served meal, with a small bottle of Australian wine added, can easily be got for a shilling, and this includes all those extras of bread and attendance for which a special charge is made in so many places. These prices argue cheap meat, cheap vegetables, and cheap fruit, so that the frugal housewife can make a little money go a long way when marketing. Fruit, in season especially, is cheap. Fresh grapes, peaches, apricots, pears, and plums can all be bought at prices ranging from twopence to threepence a pound, and all of the very finest quality. I have often seen twenty pounds of ripe tomatoes offered at the door for a shilling, and a ripe water-melon a foot in diameter, with flesh pink and crisp and luscious, for threepence. Sixpence buys three good pineapples from the hawker's barrow, and the wine-flavoured passion-fruit may be had at threepence a dozen. If the Australian workman does not live well, it is because he does not care to, or his wife does not know how to buy.

For clothing of all kinds, he has to pay high prices, and he does not forget while doing so that he is contributing to the maintenance of the pro- 


\section{Life in the Cities}

tected industries of the country. To do him justice, he does not complain of this, for there is no more staunch adherent than he to the protective principles which, rightly or wrongly, he connects with the high scale of wages he is able to earn. The necessary luxuries of the working-man, tea and tobacco, are both cheap and of good quality in Australia. When the Australian tariff was framed, the Labour representatives in the Commonwealth Parliament, by a clever combination with the Free Trade party, obtained the exemption of tea from any duty whatever, contending that it is one of the Australian working-man's necessities. A comparison between the prices paid by the British and Australian workman for tobacco is not easily effected, since the Australian usually smokes the best American tobacco, which he buys in the form of a hard plug containing little moisture. I recently obtained in London, after a good deal of trouble, a plug of this tobacco, for which I paid two and sixpence. In Australia, the same article would have cost, at most, but one and sixpence. There is another luxury that costs less to the Australian than to the British workman, and it is to his own credit that it is so. The Australian contrives to spend a smaller sum upon intoxicating drink, although the public-house prices of beer and spirits are higher in Australia.

These are some of the material advantages which the workman enjoys in Australia, and they have their natural complement in social 
advantages, upon which the better-class workman sets even a higher value. It is literally true in Australia, at the present time, that there is no position of importance in the State to which an ambitious and able man may not climb. The careers of the men who were Premiers of the Australian States at the time these words were written illustrate this fact with special force. The Premier of one state formerly worked in a flour mill within a hundred yards of the Parliament House where meets the Assembly he now leads. Another Premier can boast that he once carried his swag in search of employment through the country districts of his state, and yet another was at one time an insurance agent. Instances of this kind could be multiplied to any extent, for they illustrate the rule rather than the exception. The Australian workman fully appreciates these possibilities, and the absence of class distinctions they imply, and shows his appreciation by an independence of conduct which is very noticeable. It cannot justly be said that this independence is allied to any discourtesy of bearing, but he knows his own value, and is also fully alive to the importance of the political power he wields.

The ambition of the Australian workman is usually apparent in the career he marks out for his children. To them, the learned professions are open, and he is not slow to take advantage of the fact that the State-subsidised university is at his very door. I remember a typical instance of 
a hard-working tradesman with a large family, whose second son had shown remarkable ability when attending the free State school. With praiseworthy self-denial, this man paid the fees for the boy's attendance at a secondary school until he matriculated, and then, with the assistance of his eldest son, also an artisan, entered him at the university. The boy lived at home humbly enough, but his parents were careful that there should be nothing in his dress or in his circumstances that should mark him among his fellow students. His university career was successful, for he took a surgeon's degree, and he is now a country doctor with a good practice. $\mathrm{He}$ has been, moreover, able to help his younger brothers and sisters to follow in his steps. Let it be said again that this is no exceptional case, but merely an instance of the possibilities for advancement open to the working class in Australia.

The pleasures of the workman are largely governed by the climatic conditions of Australia, which means that he spends a great deal of his leisure in the open air. There is no lack of space in the big cities if he has a mind to indulge in cricket or football; or he can take his place as a spectator and watch these games played by their finest exponents. Cycle racing has never lost its hold on the Australian public, and there are many other pleasant ways of spending the Saturday half-holiday. The number of whole holidays 
observed in Australia is not small, and the Australian knows how to enjoy himself on these occasions. Sydney Harbour on Boxing Day or Anniversary Day (January 26th) presents one of the finest sights imaginable, with its fleets of gay excursion steamers all crowded with happy, welldressed people. Cheap excursion trains carry picnic parties away to shady gullies, where the creeks bubble pleasantly under the tall tree-ferns, and the air is pure and exhilarating. It is not far from any big city to the seaside, where there are broad stretches of clean sand, and fires may be lighted, and billies boiled in the shady tea-tree scrub. These are the holiday resorts, not of the few, but of the many, and it has to be said that the Australian method of keeping a holiday goes far to justify the frequency of such occasions.

One of the least agreeable features of the Australian holiday is the prominence of the larrikin "push." The larrikin has his equivalent in most big cities, and may not differ much in type from the English Hooligan, the American Tough, or the French Apache, but there can be no doubt that he is more in evidence than any of his prototypes in the Old World. The larrikin pushes, or gangs, are recruited from youths of the working class, whose tastes incline in the direction of brutality and conspiracy. The old bait of mystery, always so attractive to a certain type of degenerate, allures many of them to the ranks of the pushes, some of which claim to possess the organ- 
isation of a crude sort of secret society. One ingenious Australian writer ${ }^{1}$ declares that the code of rules binding one well-known Sydney push prohibits drunkenness and unchastity, and that the common bond among members is one of murder. Each initiate, before being admitted to full membership of the society, must take part in the doing to death of some person who has rendered himself obnoxious to the push, and must afterwards sign a confession admitting the full guilt of the crime, the possession of which document ensures his fidelity to the gang. These startling statements were put forward in apparent seriousness in Blackwood's Magazine of July, I901, but no convincing evidence in support of them was adduced.

It is very certain, however, that the secrets of the pushes, if they have any, are well kept. Their meetings are quite apparent to any observing person who cares to look for them, and it can be proved from the Australian newspapers that they sometimes deal very roughly with the policeman who concerns himself too actively in their ordinary pursuits. Occasionally a battle between two rival pushes takes place, when sticks and stones fly about freely, and sometimes an injured larrikin finds his way to the hospital. $\mathrm{He}$ usually professes himself unable to identify his assailants, and in the absence of positive evidence, it is difficult to bring the offenders to justice. I

\section{${ }^{1}$ Mr. Ambrose Pratt.}


have personally known cases where the push has provided funds for the legal defence of a member accused of some crime; and I have known of members of the same push who have been utterly deserted in their hour of need.

The amusements of the push-and it exists primarily for the sake of amusement-are dances, picnics, and, on special occasions, organised rowdyism. The young women who figure at the dances and picnics have the same taste for feathers and high-heeled shoes that distinguishes the coster-girl, and the same facility of repartee, disconcerting in its allusive obscurity. The male larrikin at one time favoured a distinctive dress, consisting of a short coat with a velvet collar, an open vest, and narrow neck-tie, bell-bottomed trousers, and a soft felt hat with a broad stiff rim. Of late years, this costume has gone out of vogue, and has been replaced by nothing likely to distinguish the push member from his fellow-man.

Push dances are remarkable for their solemnity and observance of push etiquette, and for a weird dance known as a teetotum, which resembles dimly the ghost of a waltz fettered in heavy chains. Push picnics are enlivened by the music of the mouth organ and the accordion, and by a free use of stimulants. They not infrequently end in a free fight.

It is difficult to make any excuse for the existence of the larrikin and his push, for the opportunities for rational amusement in the Australian 
cities are in no way restricted. The efforts of the police to break up the bands are checked, in some cases, by the unwise leniency of honorary magistrates, and by the extreme difficulty in proving any punishable offence against the ringleaders. The larrikin, leaning against the dead wall and spitting idly into the gutter, is an eyesore in the Australian cities, and an intolerable nuisance as well. When his worst passions are roused, he is a positive source of danger, and the perpetrator of many cowardly crimes, the consequence of which he too often contrives to escape. His existence may well be a source of uneasiness to those concerned in the future of the new nation.

The worst slums of the Australian cities are undoubtedly those quarters given up to the occupation of the coloured aliens, - especially the Chinese and Hindoos. The greater part of the laundry work has lately passed into Chinese hands, and the Chinese cabinet-maker has also entered into very serious competition with the Australian tradesman. These men gravitate to the most undesirable quarter of the town, and, by herding together in defiance of all laws of sanitation, render it still more undesirable. Opium-dens and gambling-houses are open night and day, and form an attraction for the most degraded of the white population of both sexes. Chinatown has an aspect and an odour all its own; an air of shabbiness and dinginess pervades the buildings, and from the open doors come indescribable 
whiffs of burning joss-sticks blended with decaying vegetable matter.

Chinatown usually contains at least one Chinese restaurant, patronised both by Orientals and white folks. In the inner room, a party of young Bohemians, in faultless evening dress, may be seen enjoying the novelty of a dinner in Chinatown, and straining the resources of the establishment by demands for mysterious dishes and piquant sauces. In the large outer department, grave Chinamen empty their bowls of savoury rice with startling rapidity by a deft manipulation of the chop-sticks, and a pair of larrikins, trying to imitate them, fail to lift as much as one grain to their lips with implements so unsatisfactory. Pigtailed waiters flit nciselessly hither and thither, and the watchful proprietor, bland and inscrutable, allows nothing to escape his notice from his elevated perch near the door. Next door is a gambling-house, where tickets are marked and fan-tan is played in an inner room, while not far away is a stuffy chamber where four or five Chinamen and as many Europeans are dreaming blissfully in an atmosphere tainted with the smell of burning opium.

The distinctive sights of the Australian streets include the Chinese vegetable merchant, with his two heavy baskets of vegetables, balanced on a bamboo pole, supported on his shoulders. A group of Hindoo or Syrian hawkers may be seen passing from house to house, pressing their cheap 
wares in the most imperfect English. More peculiarly Australian is the rabbit-man, with his stentorian yell of "Wild rabbits, oh!" and his cart with a frame on which dozens of pairs of slaughtered bunnies are hanging. One shilling a pair is the usual price, and the rabbit-man does a thriving trade in the face of an expiring Australian prejudice against the rabbit as food. Australian shops are much the same as shops anywhere else, but the fishmonger and game-seller sometimes festoons his shop front with strings of brightplumaged parrots, useless as food, but attractive to the eye. Curious fish are on the marble slabs, pink schnapper, and hideous flat-head, with silver barracouta like enormous mackerel, and piles of tiny garfish. The game includes wild duck, magpie-geese, and black swan, with a wallaby or two and tails of the larger kangaroos. The wild turkey-which is really a bustard, and the finest game bird Australia produces-may occasionally be seen, but it is now very rare and shy. The game-shop and the fruit-shop serve best to remind the visitor that he is in an Australian city; none of the others differ in any particular from the shop of a British city.

A stroll through a suburban street in the cool of the evening is quite another affair. Here the houses are all single-storied bungalows, or villas, as the Australians prefer to call them, each standing in its own plot of garden. Glance over the famous pittosporum hedge, and you may see the 
lawn sprinkler pleasantly at work under the pepper tree that grows in the middle of the grass plot bordered with masses of bright phlox and thriving roses and pelargoniums. The bamboo blind, which has been down all day to keep the sun off the bousefront, is now rolled up, and in an easychair on the veranda reclines pater-familias, clad in cool flannels. Doors and windows are open to admit the evening breeze, but before each is a wire screen to exclude flies and mosquitoes. From the drawing-room comes the sound of voices, mingled with the strains of the latest comic opera. It is a glimpse of the Australian at home.

There is an air of roominess and privacy about these suburbs that stands for a good deal of solid comfort. The citizen swings in his hammock and smokes his pipe without any consciousness of being observed from the top floor of some building close at hand, for a day's march through the suburbs of an Australian city will fail to reveal anything in the shape of "residential mansions." The most arduous task of the amateur gardener is the constant use of the watering-can; the rest is done by Nature with a lavish hand. The vine and the fig tree are by no means impossible, and a rough erection of wooden laths makes an ideal fern-house. These things figure very largely in the life of the average Australian city dweller, who leaves his city office at five, changes into easy clothing as soon as he arrives 


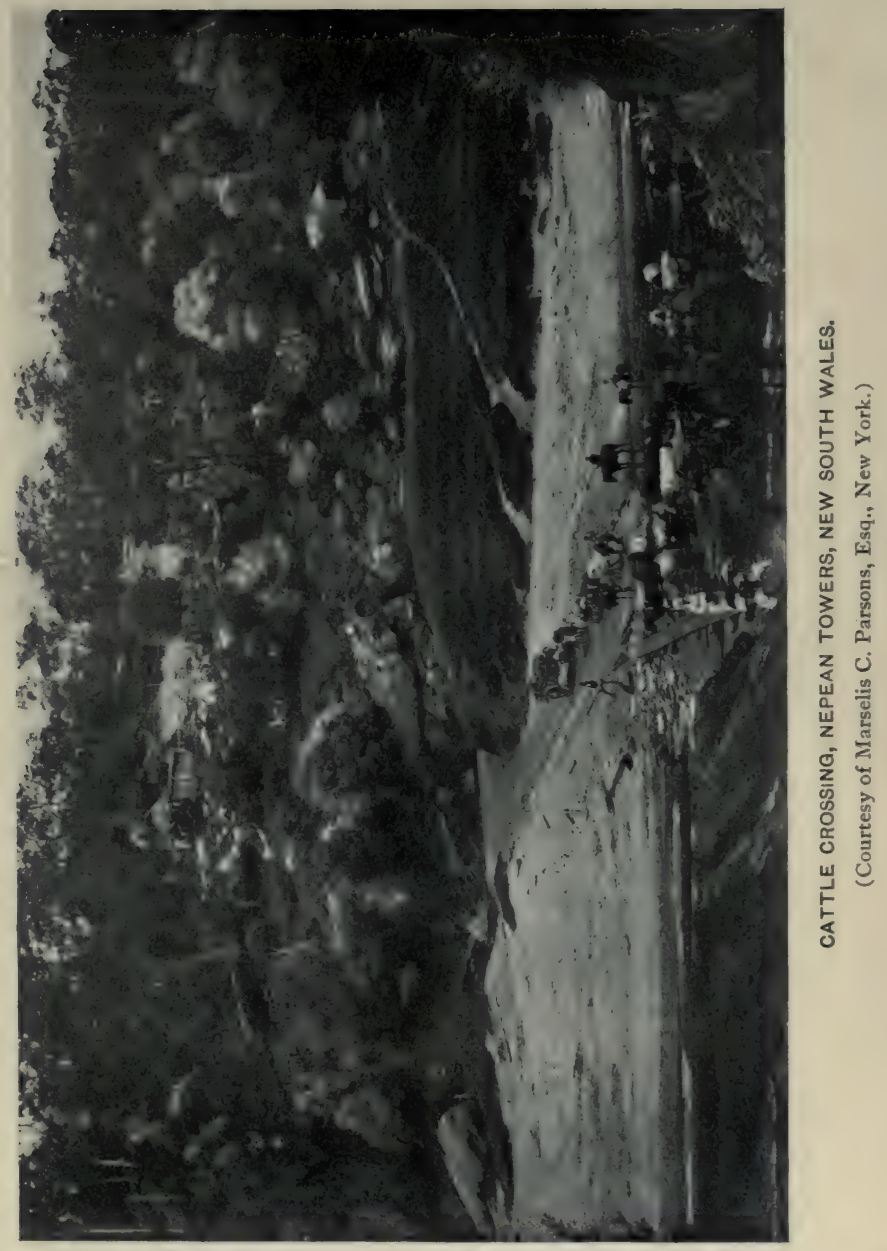





\section{Life in the Cities}

home, dines comfortably about half-past six, and then potters about his garden until it grows dark. A few friends may call for a game of cards or a little music, and a supper follows in which fruit and light wines or lemon squash are prominent items. The office or the warehouse claims him at nine o'clock the next day, when, as we have seen, he must plunge again into the headlong rush of Australian business.

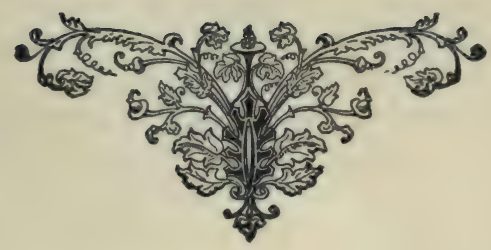




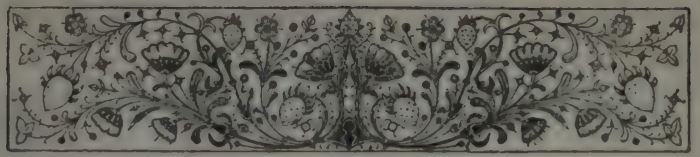

\section{CHAPTER $\mathrm{X}$}

STATE SOCIALISM AND THE LABOUR PARTY

THE Australian answers truly to Aristotle's description of man as " a political animal," and his interest in politics may be set down as the inevitable result of the intimate relations existing between the people and the State. The choice of his rulers is a matter of the deepest concern to a man who encounters the results of their administration at every turn, and as the tendency in Australia is to increase rather than to diminish the functions of the State, the Australian not unreasonably bases his political opinions upon the events of his everyday life. Those who dwell in the bush have the State for landlord, and can, in bad seasons, obtain the remittance or postponement of the collection of rent. The State owns the railways which carry their produce to the seaports, and, by an increase or reduction of freights, may materially affect their prosperity. The State undertakes the education of their children, establishing the schools and maintaining the teachers, while grants of money for the construction of roads and bridges may also be obtained from the 
State. To the same source, they look for police protection and postal and telegraphic services, and for help and supervision in the establishment of new industries. After bad seasons, the State supplies them with seed wheat, and sometimes advances money to tide them over to the next harvest.

For the artisans and miners, the State does even more. It regulates the conditions under which they work and their hours of labour, and even fixes their rate of wages. It decides industrial disputes between Labour and Capital, enforces the closing of shops at certain hours, and supervises the workshops and factories. It buys the miner's gold, and opens up markets for the producer in foreign countries. In one Australian province, the State has turned publican, and retails beer and spirits of the best quality at the smallest percentage of profit. When the workman falls out of employment, the State accepts the responsibility of finding work for him; and when he becomes too old to toil any longer, it pensions him off."

The first result of this condition of affairs is the existence of a large official class in the employment of the State. Public servants there are, of course, in every community, but it is doubtful whether any country maintains so many in

1 The functions ascribed to the State still differ in the various political divisions of Australia, and these statements hold good only for some of the Australian States. 
proportion to its population as Australia. The administration of the vast areas of public lands, the maintenance and working of thousands of miles of public railroads, the education of the children, and the policing of the country alone involve the employment of many thousands of civil servants. Each new function assumed by the State necessitates the creation of a fresh department, and a further addition to the vast army of the Stateemployed.

These people are united by common interests, their position being defined by legislative enactments which affect them all alike. When all exercised the franchise, they were able to show their resentment at measures of retrenchment and economy in so marked a manner as to cause political uneasiness, and in one state at least it has been found necessary to restrict their political representation to special members whom they may appoint to represent their interests in Parliament.

As the State is so large an employer of labour, it is only natural that those seeking employment should turn first to the State. Short hours, regular employment in a position which can only be forfeited by misconduct, and a salary which annually increases by a small sum, are strong inducements to the father who wishes to place his son in life. As a consequence, there is keen competition for all Government positions, and the interference of politicians was at one time so frequent as to give rise to something like a scandal, 


\section{State Socialism}

the public service having been over-manned with nominees of various members of Parliament, who seldom cared whether the servants they forced upon the country possessed any special fitness for the work they were supposed to do. A strong manifestation of public feeling took place throughout Australia in consequence of this practice, and it was abolished, the public service being removed -nominally at least-beyond the sphere of political influence.

But there is another class which demands, and frequently obtains, employment from the Government. These are the mechanics and artisans of the cities, who may have been thrown out of work owing to a temporary slackness in the trades in which they are customarily employed. Such dull seasons not infrequently occur in the Australian cities, and the out-of-works congregate upon some spare plot of ground, listening to the speeches of men whose one cry is that it is the duty of the Government to provide them with employment. These meetings of the unemployed usually end in a march to the Government offices, where the leading agitators demand interviews from members of the Ministry and from the Governor. Should they obtain the desired interview, they demand work as a right, referring to the many public works it will be necessary to construct in the future, and suggesting that some of these shall be put in hand at once, the cost to be met, of course, from borrowed money. These 
unemployed of the cities contrast but poorly with the unemployed of the bush, who bravely shoulder their swags and tramp off in search of the work they never think of demanding from the State.

A reference has been made to borrowed moneys, for it is impossible to avoid some notice of Australian financial methods. The railways and other public works have all been constructed with money borrowed from the British investor, and these loans involve the payment of a sum of more than $£ 9,000,000$ each year in interest alone. At present, there is no attempt to make the railways return the interest upon the money they have cost to build, or any further sum that might go toward repaying the principal. The policy is rather adopted of working the railways for the immediate benefit of the people, and for the purpose of developing the resources of the country. Each fresh enterprise means an addition to the debt of the country, and it cannot be disputed that the people who enjoy the convenience and cheapness of State-owned railways in a land that is far from being settled are piling up for their descendants a heavy obligation, that must some day be met. A people holding the advanced opinion that no man willing and able to work should be refused employment by the Government ought at least to avoid the injustice of indulging in philanthropy, while leaving the bill to be settled at some time in the difficult future. 


\section{State Socialism}

It is the knowledge that the future of Australia has been so liberally discounted by the loan policy that tempers the admiration which is certainly due to the Australians for their provision for the aged. There are now many aged couples in Australia who are living in content in the little home they have made, and who, under a less humane system, would be separated and forced into charitable institutions. Not all the Australian States have adopted the system of old-age pensions, and it is true that instances have occurred of these benefits bestowed upon persons undeserving of them. These, however, are but faults of administration, and cannot be urged against the principle itself.

In the same spirit of humanity, Australia has experimented with legislation designed for settling the differences between Capital and Labour, and preventing the occurrence of strikes. The laws under notice provide that all such disputes shall be settled by an Arbitration Court, over which a judge presides, while representatives of both sides help in its constitution. It is claimed that these courts have worked satisfactorily on the whole, although some grave defects have come to light in the operation of the Arbitration Acts. This principle of compulsory arbitration is one of the foremost doctrines of the political party known as the Australian Labour party. As this political party, now rapidly growing in power in the Commonwealth, promises to exercise a notable 
influence upon the conditions of life in Australia, and as it advocates a wide extension of the prin. ciples of State socialism, some account of it and its aims is necessary.

The weapon employed by the Australian workman to secure the eight-hour day was Trade Unionism; and in order to celebrate his victory, he appropriated an annual holiday. A monument bearing the inscription, " Eight hours work, eight hours recreation, eight hours rest," is erected in the city of Ballarat to the memory of one Galloway, a protagonist of the cause in that city. Elsewhere in Australia, men equally unknown to fame are similarly preserved from oblivion, but the Festival of Eight-Hours' Day is the most striking memorial of the first Labour victory. From that time forward, the Labour party trusted in its unions, and fought Capital by means of strikes and threats of strikes. For a time the unions carried all before them, and the men flocked to their banners. Trade was brisk and work was plentiful, so that the unions were able to accumulate very considerable funds. They pressed their advantage too heavily, however, and drove the employers into a combination against them.

The two opposing forces came into collision in the year I89r, with results from which Australia has not yet recovered. The quarrel began with a maritime strike, which laid up the vessels plying between the various Australian ports, and 
soon spread far and wide throughout the continent. The whole pastoral industry was dislocated by a strike of shearers, and, among other actions, the Labour leaders alienated public sympathy by calling out the gas stokers, and leaving the city of Melbourne in darkness. It was a long battle, and bitterly fought out. The men had ample funds to draw upon in the beginning, and showed remarkable courage and resolution in fighting to the very last. But they were fighting a losing battle, in which Australian Trade Unionism was shattered by a blow from which it was predicted it would never recover.

It is true that the unions have never recovered the prestige they lost in the great strike, but the defeat of the men stiffened the cause of Labour in Australia as even victory could not have done. The method of fighting was altered-that is all, and the scene of combat was transferred to the ballot-box. The Australian workman, remembering that he had a vote, determined to employ it to the one end of furthering the object of the Labour party. The representatives of Labour who contrived to be returned to Parliament went to work in the same way-they consistently played one political party against another, while standing aloof from both, ever on the look-out for some legislative advantage for Labour.

Before the Federation of the Australian States, the Labourites were continually held in check by the Upper Houses of State Legislature, composed 
either of nominee members or members elected on a very restricted franchise. The Commonwealth, however, has been provided with a constitution more democratic than any of the Australian States possesses, since the broad principle of universal adult suffrage governs the election of both legislative chambers. The accomplishment of the Federation furnished the Labour party with an opportunity, and they were the more readily able to grasp it, because, with the new era in Australian history, they broadened their base and extended their objects. From its inception, the Federal Labour party has been devoted to State Socialism, and has attracted supporters, and especially leaders, who are Labourites only in one sense of the word.

The majority of the Labour members of the Commonwealth Parliament are not workmen, but professional men-barristers, doctors, jourualists, and master printers. The British workman, who has a profound mistrust of the class immediately above him, prefers to give his vote to a man of his own class, or to one whom he describes as a "real gentleman." The Australian workmen, on the other hand, have more than a suspicion that the disaster of the great strike was brought about by unskilful leadership. " Lions led by asses," they were called at the time, and the phrase sticks. They have now chosen for their leaders men who are fighting their way upward in the professional ranks, and they have no reason to complain of the 


\section{State Socialism}

result of their choice. The leaders of the Commonwealth Labour party, and its representatives generally, are equal in ability, education, and general grasp of political affairs to those with whom they come politically in contact.

What the party has accomplished, and hopes to accomplish, can best be gathered by reference to the programme put forward for the elections at the end of 1903. The main planks of the platform were: a White Australia, arbitration and conciliation, old-age pensions, nationalisation of monopolies, a citizen defence force, restriction of public borrowing, and navigation laws. The first of these objects had been gained by the passing of laws during the term of the first Commonwealth Parliament, by which coloured aliens are excluded from Australia. The second and third objects involve the application to the whole continent of principles enforced in some of the states, though not in all. The fourth plank in the Labour platform is capable of a very wide interpretation. Among the other monopolies it is proposed to place under State management may be mentioned the sale of intoxicating liquor and tobacco. The Labourites also advocate State development of the deposits of iron ore in Australia, and the establishment of a State bank of issue, and State life and fire insurance departments. From the mining of iron by the State to the mining of precious metals is an easy step, and the advocates of private enterprise are able to see in 
this vaguely worded policy a very disquieting menace.

The restriction of public borrowing implies an alternative of heavy direct taxation, if public works in Australia are to be constructed in the future as in the past. This taxation, the Labour party indicates, should take the form of a land tax, framed in such a way as to press with special weight upon absentee owners and the proprietors of unimproved lands. In any case, the members of the party adhere firmly to the opinion that the large public debt of Australia should not be further increased, and by consistently maintaining this view command the sympathy of many who are not in accord with their general aims.

Upon this programme, the Labour party went to the polls for the Commonwealth election of 1903. For many months before the election, the labour organisations were at work, distributing propaganda, and selecting suitable candidates. For the women's vote, exercised for the first time at that election, the proposal for the regulation of the liquor trade was a tempting bait, since the experience of New Zealand and South Australia has shown that in this subject of all others the woman rather is most keenly interested. The result of the election was a remarkable triumph for the party, which received a notable accession to the number of its members in both Houses, and especially in the Senate, or Upper House of Legislature. In the session that followed an unexpected 
turn of the political wheel gave the Labourites an opportunity of assuming office. Mr. Watson, the leader of the party, succeeded in forming a Ministry, and the world was afforded the spectacle of a continent of three million square miles being governed by representatives of the working-classes. After a few months' tenure of office, however, the Labour Ministry had to face a combination of the opposing parties, which was brought about by the too Socialistic tendency of its proposed legislation. The Labour party was accordingly forced to vacate the Government benches, but not before its leaders had shown their possession of considerable administrative firmness and ability. The Labour party still remains the only political organisation in Australia which possesses cohesion and a definite policy, and to this fact a large measure of its success may be attributed.

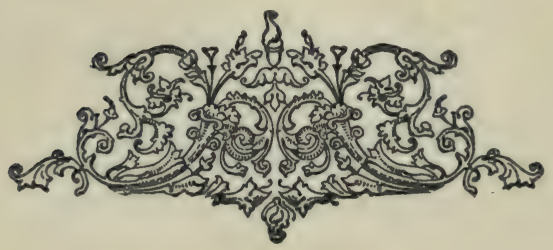




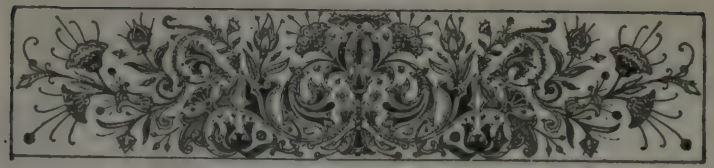

\section{CHAPTER XI}

\section{GOLDEN AUSTRALIA}

IN order to understand how Australia was quickened into life as if by magic, when the golden discoveries of half a century ago were made, it is necessary to visit one of the inland cities called into existence at that period. Of these, the city of Ballarat is perhaps the most famous, and it is certainly one of the most interesting illustrations of the transformation effected in fifty years of Australian history. Standing in a broad and fertile valley, this trim and well-built city of forty thousand people to-day bears little resemblance to any preconceived notion one may have formed of a mining town. Its principal street is an avenue two hundred feet wide, with a double row of tall oaks and encalyptus trees running up its centre. In the very heart of the city is a public square, where white marble statues, that stand unsoiled in the open air, have been set up in honour of Shakespeare, Burns, and Moore. Looking eastward from this square, beyond the outskirts of the city, the land rises to two great volcanic hills, clad from foot to crest in forests of 
dark-leaved eucalyptus. Broad straight streets intersect the main avenue at regular intervals, and each of these in its turn is an avenue of eucalyptus, oak, and pine. Pleasant villas and neat cottages line the streets, and everywhere are gardens and trees. On the western boundary of the city was once a dismal swamp, now converted into a beautiful lake, fringed with weeping-willows and surrounded by plantations of ornamental trees. On the farther shore of the lake is a beautiful pleasure ground, where marble statues gleam amid fern grottoes and rose bowers, and children play all day on lawns of soft English grass shaded by trees drawn from every quarter of the globe. It is a city of gardens rather than a city of gold.

Sixty years ago, King Billy and his tribe of aborigines roamed in undisputed possession of the valley, then covered with virgin bush. Ten years later, a hundred thousand diggers were living under canvas on the field, and the roaring days of Ballarat had begun. Some of those diggers are still alive in Ballarat, old men who have seen the city advance through its fifty years of history, and can point to the spot where some tall building stands and say, "Here I sank my first shaft, and there I bottomed on a hatful of nuggets." Ballarat, these veterans will tell you, has its spots of historical and romantic interest. Here is the forge where one picturesque digger had his horse shod with shoes of gold, and hard by is the hotel where lucky miners lighted their pipes with 


\section{$136 \quad$ Australian Life}

five-pound notes, and adorned the barmaids with necklaces made of virgin nuggets. The theatre where Lola Montez sang and danced her way into the hearts of thousands of red-shirted men-not one woman in the whole house-and the stage where she stood bowing amid a golden shower of nuggets and specimens; these have been pulled down, but a monument marks the spot where the digger and the soldier tried conclusions-the site of the Eureka Stockade.

Twenty years after the gold discoveries, Ballarat was a city of wood and canvas. On "The Corner," not far from the present Square of Statues, was a busy share mart, where men stood all day in the open air, buying and selling mining scrip. The roar of quartz batteries lulled the children to sleep each night, and between the shops and houses were reared the "poppet heads" and heaps of tailings that marked the situation of active mining operations. When a rich discovery was made, the throng of open-air speculators on "The Corner" stretched across the wide street, and undeterred by the fall of night, these gamblers continued to buy and sell their shares by the flickering light of an occasional candle. "Coined into sovereigns," your ancient guide will tell you, "the gold taken out of Ballarat would stretch in a long line across the continent. But," he will add, with a mournful shake of his head, "very little of it has remained in the place."

But Ballarat does not live in the past. The 
worked-out mines have been filled up, the unsightly "mullock heaps" have been removed, while woollen mills and factories for the manufacture of agricultural machinery have been erected on the exploited ground. In the outskirts of the city, mines may still be seen, and any one curious and adventurous enough may descend thousands of feet below the surface of the earth to see the miners working the veins of sparkling quartz. Here and there, a vacant area of land, scarred with hundreds of abandoned shafts, remains as witness of the thoroughness with which the gold district has been explored. But the golden era of Ballarat is practically at an end, and the city is now the centre of one of the most fertile agricultural districts in all Australia.

The miners went to Ballarat and stayed there, but auriferous Australia is dotted with deserted mining camps where nothing remains to recall the glories of the past, except the gravel heaps and gaping holes the diggers left behind them. A store, a post-office, a hotel or two, and half a dozen cottages, with perhaps a noisome little Chinese camp to prove that the yellow man can glean a living from the leavings of the white man. And in its palmy days, the "rush" had been a human ant-hill, where forty thousand diggers toiled feverishly all day, and drank, gambled, and sang through the nights in their fire-lit canvas tents!

These are the dying goldfields and the dead 
ones. Over in Western Australia is a golden city in the desert, not ten years old, but already replete with all the conveniences of a great modern city. Here in Kalgoorlie, men live by gold alone, and talk only of mines and mining shares. Day and night, the thud of the quartz batteries is never hushed, and almost every day, a precious freight of golden bars and cakes is despatched by train to the capital for coinage. It is a city of big mines, equipped with all the most modern appliances for extracting the last fraction of gold from the ore. Kalgoorlie is situated in the arid belt, and since the operations of these mines require a plentiful supply of water, a stream has been dammed and a great reservoir made near the coast. From this reservoir, the water is pumped through steel pipes for a distance of more than two hundred miles to drive the engines and fill the sluices of the Kalgoorlie mines. It is a wonderful place, this golden city in the desert. In its big hotels, bronzed prospectors in evening dress discuss their future plans over elaborate champagne dinners. In another month's time, these men, clad in flannel shirt and soiled moleskins, and begrimed with the red dust of the dry-blowing machine, will be living on tinned meat and condensed water. Now they ride on electric trams and motor-cars, and take their pleasure in a great theatre or at a race-course where stakes worth a thousand pounds are decided.

Two hundred miles further inland, a straggling 


\section{Golden Australia}

procession of men is making its way across the unknown desert to a place which, men say, holds wealth surpassing the mines of Kalgoorlie. Well in the front of the procession ride the cyclists, each with his store of water in a tin cylinder that is strapped in the diamond frame of his machine. The cyclist prospector carries food and water only, leaving the rest of his belongings to be borne by the slower drays that follow in his track. Next come the horsemen and camel riders, and men driving buggies drawn by teams of horses; and after them the heavy drays and the long-drawnout train of footmen. Some of these carry their swags, some trundle their tools and belongings in wheelbarrows, and one or two have packed their necessaries in a barrel, and, fastening the head securely in, roll it patiently over the track. These, and the man who is pushing a baby's perambulator, give a touch of comedy to the "rush" that is making its way to the new find at the "Back of Beyond."

But the situation holds all the possibilities of the grimmest of tragedies. If, as too often happens, these men who tramp so bravely and hopefully across that arid plain are only pursuing a will-o'-the-wisp, a phantom Eldorado that vanishes with its first gleam of golden promise, some of them will never come back. Every one of them knows it, from the youngster who pushes eagerly forward with shining, hopeful eyes, to the stern-lipped veteran, grey with the disappoint- 
ment and hardships of a hundred " rushes." If they stopped to reckon up the risks, their chance of "pegging out " a good claim would be a very small one. Therefore, the prospector must put dangers behind him, or face them with the pluck and endurance that comes from a brave and hopeful spirit. The whitening bones of camels and horses are not the only objects that serve to remind the traveller on these Western plains that if the rewards offered are great, the risks are great also. Wherever the prospector has been, there may be found the graves of the pioneers-just a mound of sand, with a rough railing of wood, fencing it from the surrounding desert. Sometimes a wooden slab or tin plate proclaims the name of the man who rests there, but very often these graves in the wilderness are nameless, because the names of the dead men were not known to the miners who buried them there.

Their story they could easily have told, for many of them had been within an ace of enacting it themselves. A too bold incursion into unknown wastes, a dried-up water-hole, and an empty water-bag, and then the awful delirium of thirst under a fiery sun. And somewhere on the green Eastern coast, a lonely woman waiting for a letter that never comes. Every Australian prospector knows that story by heart.

But let us accompany our Argonauts in their plucky expedition to the rush at "Back of Beyond." On arrival there, they learn the good 


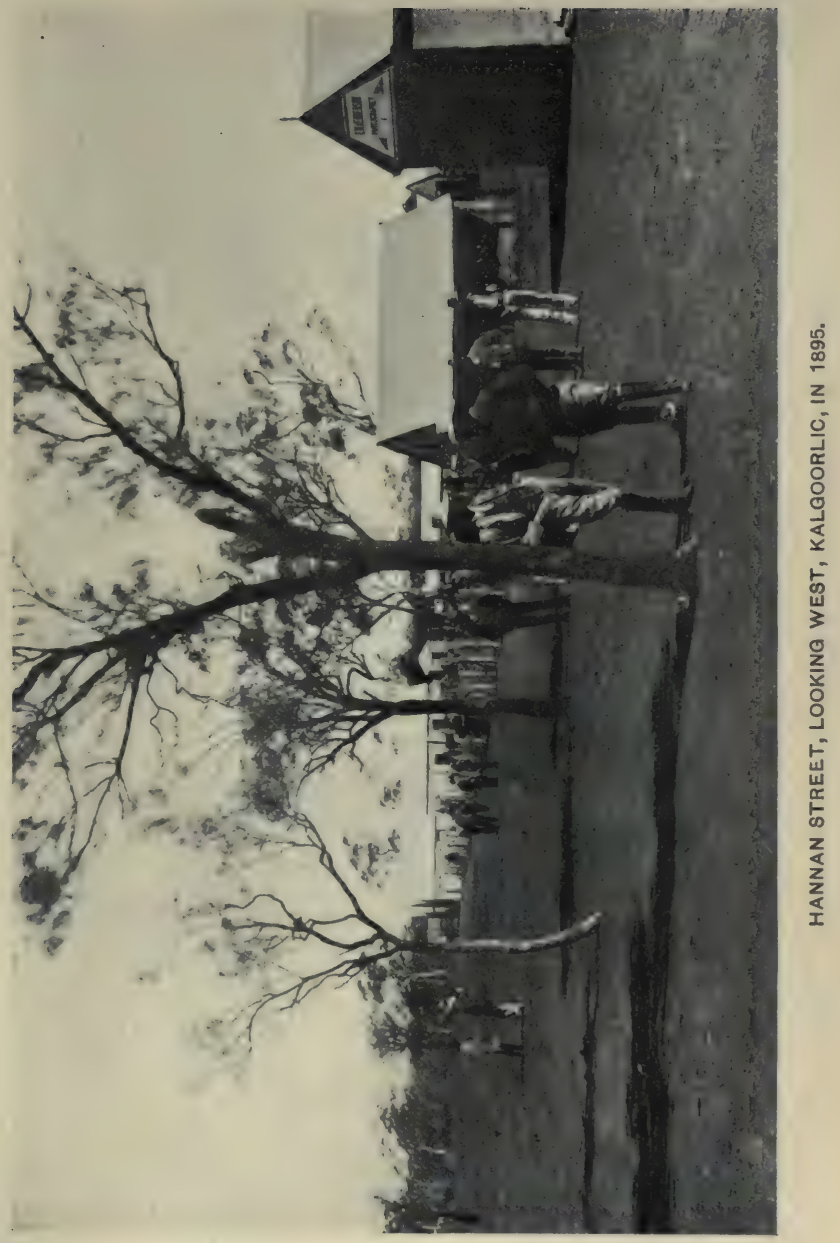



news that a big reef has certainly been located, and that the prospects for alluvial miners are more than promising. The ground is soon pegged out in all directions, and the "dry blowers" can be seen at work all over the field, sifting the alluvial soil through sieves which allow the dust and sand to pass but retain the golden nuggets. From somewhere,-apparently from the trackless wilderness, - a grog-seller has arrived with his barrels and bottles, and is already doing a roaring business in a tent which a small hand-written card, pinned on the tent flap, proclaims to be a hotel. Another man is distilling clear tasteless water from the salty mixture in the lake, and selling it at half a crown a gallon. The camp has passed from the vague realms of rumour and hearsay into the region of absolute facts.

Work is going on busily everywhere, when the sound of a tin dish beaten with a stick is heardthe call for a "roll-up." In an instant, work is at a standstill, and every occupant of the camp hastens in the direction of the sound, to discover what matter of common interest is to be settled. The cause of the "roll-up" is soon made known: a miner's tent has been robbed, and his chamoisleather bag of nuggets stolen. The victim narrates the circumstances, and explains his reasons for suspecting some other member of the camp. Some of the miners at once seize and search the accused man while others go to his tent, where the stolen gold is discovered, hidden in the thief's 
roll of blankets. In five minutes, judgment is pronounced-the thief must leave the camp within an hour's time. He must pack his swag and fill his water-bag, and then take his chance upon the track, for they have no use for him or his kind at the Back of Beyond Rush. To the credit of the prospector, it must be said that the necessity for this rough-and-ready justice is only occasionally felt, for the men who have pluck enough to make their way to these early rushes, have too much character to commit any offence so repugnant to the mind of the digger as tent robbery. We will leave Back of Beyond while its future is still undefined. It may be that beneath its red sands it hides veins of rich ore that will make it another Kalgoorlie; or six months hence there may be nothing but a heap of empty meat tins to show that men had once built golden hopes on the foundation of its barren sands.

On one of these western mining camps, there occurred a curious mining dispute between Capital and Labour. Capital in this instance was represented by the local publican, who retailed beer to the thirsty miners at the price of one shilling for a large glass. The miners, of course, enacted the part of Labour, and demanded that the price should be reduced by one half, since gold was becoming scarcer and less easily won. Secure from competition, the publican held his ground, and a beer strike was proclaimed by the men. For some weeks, the conflict went on, 
when the publican, who possessed some political influence, arranged that the Minister of Mines should visit the fields. On the arrival of that dignitary, -who came in all innocence,- the men held a meeting, and declared an exemption for three days, in order that the event might be celebrated in a fitting manner. It need hardly be said that the exemption was indefinitely prolonged, and that nothing more was heard of the strike. The device of the beer strike, however, has since then been adopted with success in more than one remote Australian township, where humanity is dry and liquor over-expensive.

Between these newly made mining camps of the day before yesterday and the fifty-year-old golden cities of the Eastern states, the contrast is as striking as anything afforded by Australia, the land of contrasts. And yet there is only the history of a generation between them. The sons of the men who made the garden cities of the East are helping to make Kalgoorlie to-day. In time, they too will cover the scarred earth with a mantle of green, will mend the unsightly wounds, and smooth away the traces of the ugliness they caused in their fierce greed for gold. They will make a pleasant city where life will be well ordered, and where they may rest after their adventures, and enjoy the fruits of their labours. But the adventurous spirit that moved them to leave the sober streets and waving trees of Ballarat, as it moved their fathers to turn their backs 
on the greener fields of an older land, will not allow their children to sit still while there remains new country to be explored. Ten years ago, the treasures of Kalgoorlie lay hidden and unsuspected; and Australia is wide enough and little enough known to still hold the secrets of other Ballarats and other Kalgoorlies.

"In there," said an old bushman to me once, pointing inland, "there 's all the wealth of the world-diamonds and rubies, gold and opals, in plenty. Not half of them will be found in my time, nor in yours either. No, nor in the time of our children, and our children's children. That would n't do. Australia is the richest country in the world, but it's the driest and most desolate."

It is the gold at the foot of the rainbow that supplies the key to the restlessness of young Australia.

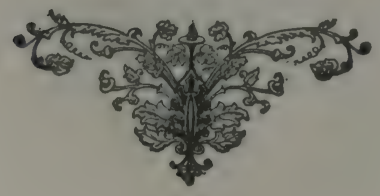




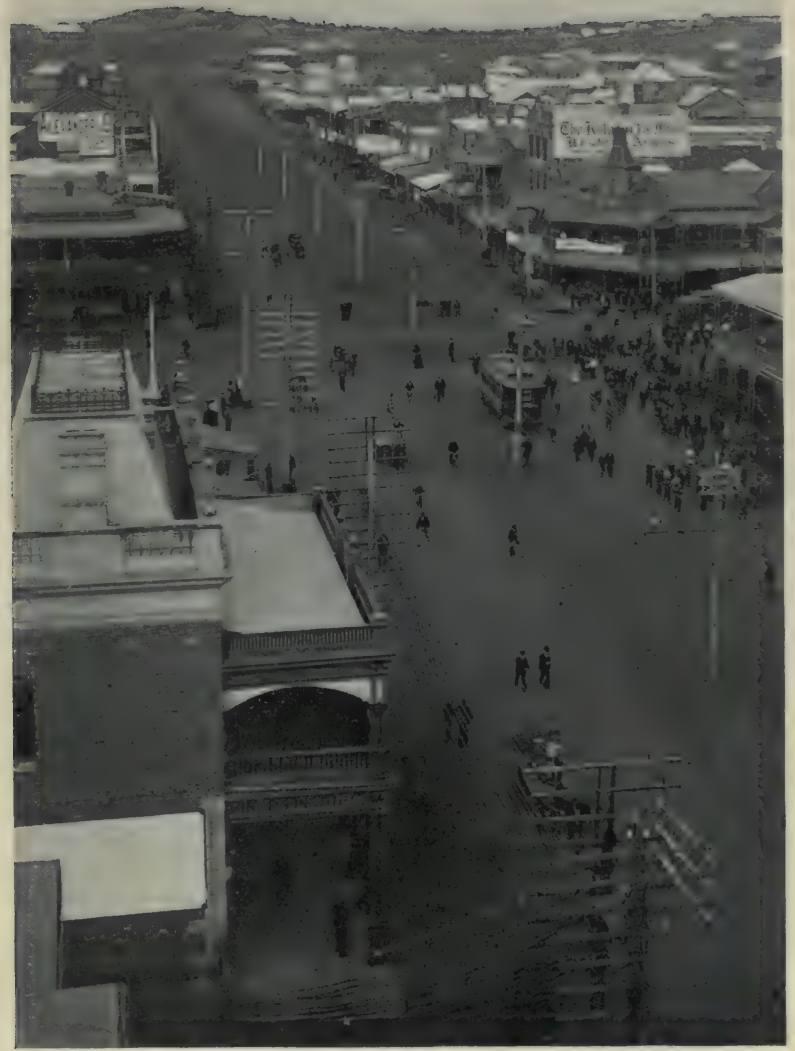

HANNAN STREET, KALGOORLIC, IN 1905. 



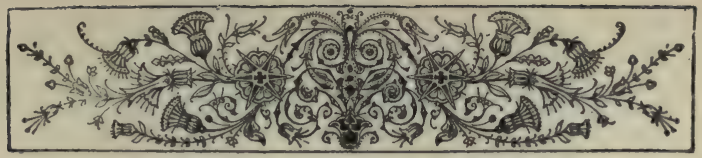

\section{CHAP'TER XII}

FARM AND FACTORY

THE selector, with his six hundred and forty acres or more of virgin land, is common to the whole of Australia. Year by year, he adds a little more to the area of land under cultivation, eking out his existence in the meantime by a little stock-raising, dairying, poultry-farming, and the like. The uses to which the cleared land is put vary according to the locality and the nature of the soil, for in a country with so remarkable a range of climate as Australia possesses, possibilities of all kinds exist. Between the Tasmanian gardener-who grows apples for the London markets, small fruits for jam-making, and root vegetables for the warmer states on the mainland-and the Queensland planter-who experiments with cotton, coffee, tobacco, arrowroot, bananas, and other tropical products-there is little that the soil cannot be made to produce. The limited nature of the local market and the position of Australia, precluding until recently the possibility of exporting produce of a perishable 
kind, have retarded the development of many of these primary industries. The latter difficulty has now been partially overcome, with the result that a fresh stimulus has been given to a number of these special enterprises.

In every state are wide areas of land suitable for the growth of cereals, some of it-and notably the Queensland uplands, known as the Darling Downs, and the wheat belt of South Australiarequiring little or no clearing. Much of the best wheat land in the south-east of the continent is covered with a growth of mallee (Eucalyptus dumosa) a shrub growing from ten to fifteen feet in height, and with stems set so closely together that it is impossible for a man to force his way between them. The clearing of this land is accomplished by hitching teams of bullocks or horses to a large tree trunk, and dragging it over the thickets after the fashion of a roller. In this way, the mallee is thrown down and uprooted, and the cleared ground is roughly broken with an agricultural implement known as a stumpjumping plough. Land that carries heavy timber must be cleared by the painfully slow process of chopping down each tree, and then "grubbing" out the stump. The fallen timber is burned in order to dispose of it, although much of it is of considerable value.

The yield of the continent for the season of 1902-3 was twelve million bushels of wheat, and for $1903-4$ sixty million bushels, showing a differ- 


\section{Farm and Factory}

ence great enough to warrant the general statement that the Australian wheat grower is at the mercy of a very fickle climate. Sometimes there is so little rain that the seed does not even germinate, or having sprouted is parched or withered without reaching maturity. As soon as the winter rains have made the soil soft enough for the plough, the ground is prepared and the seed sown, and the crop is harvested at the end of spring, that is, before Christmas time, at the very latest. Agricultural machinery of all kinds is extensively employed, and one harvesting implement frequently seen is the "stripper," which plucks the ears from the crop, leaving the straw standing. The ashes obtained by burning off the straw are often the only fertilisers applied to young ground.

The supply of agricultural labourers varies according to the season. In a good season, the greatest difficulty is experienced in harvesting the crops, owing to the scarcity of labour; but in a bad year, hundreds of swagmen may be found walking from farm to farm in search of work. These are not only men who are accustomed to work for wages, for among them may be found

- numbers of small selectors whose own crops have failed, and who have bravely gone out upon the track in the hope of earning a cheque, and so helping to keep the little home together. The agricultural labourer in steady employment earns from fifteen shillings to a pound a week with 
board and lodging. There is no act of Parliament to regulate his hours of labour, which frequently extend from early dawn till long after sunset. When it is considered that the climate is a very trying one, and that the work includes milking, clearing, burning off-a grimy and choking occupation-as well as farm work of all kinds, the conditions of his life must be accounted sufficiently hard. They serve to account for the presence in the cities of bands of unemployed clamouring for Government relief works-with pay at the rate of seven shillings for the eight-hour day, while the farmers are unable to obtain sufficient labour. The uncertainty and irregularity of agricultural employment-which I trust I have sufficiently emphasised-and the superior attractions of city life must also be considered when one is seeking to account for this state of affairs.

When a few more decades have passed, the writer of such a book as this will probably find it necessary to devote a chapter to life on the Australian vineyards. On the sunny slopes of the warmer temperate areas, the vigneron finds a soil and climate admirably suited to the production of wine of a very high quality. Among the pioneer vignerons were many French and German settlers, who have made their picturesque unAustralian homes amid the most pleasant surroundings to be found in all the continent. From the broad vine-covered, brick-paved veranda of such a house may be obtained the pleasing pro- 


\section{Farm and Factory}

spect of a green vineyard, framed in a setting of dark bush-clad hills. The vineyard, with its long orderly lines of vines, each plant standarded and tied to its own stake, is in marked contrast to the general air of untidiness that prevails in the ordinary bush settlement. Its immediate effects are the surprising quality and cheapness of table grapes in the cities, and a growing disposition among Australians to substitute wine of local growth for beer and spirits, and so to conform further to the climatic conditions in which they live.

Licenses for the sale of Australian wine are not costly, and the wineshop has long been a feature of the city streets. Unfortunately for the home reputation of the Australian wines, the management of these establishments has too often been faulty, and the method of conducting business, as well as the quality of the wine sold, has been a cause of reproach. In this respect, amendment has recently taken place, and it is now possible to obtain a glass of good Australian wine at a very moderate price, and to drink it amid surroundings holding nothing to offend the most fastidious taste. Some of the heavier Australian wines have also found their way into England, where a yearly increasing demand is found for them. The industry is better suited to the Australian climate, perhaps, than the growth of some cereals, and is attracting a very intelligent class of men, who receive the assistance of Government 


\section{I50 Australian Life}

experts in dealing with the peculiarities of soil and climate encountered.

As already hinted, the difficulty of the man on the land is not the growth, but the disposal of certain kinds of produce. I remember dining in Melbourne once, and enjoying some canned apricots which came, as I learned on asking, from America. Three days later, I was assisting to destroy an orchard of apricot trees two acres in extent, their owner having decided to replace them with orange and lemon trees. The trees were in their prime, and had never failed to yield good crops of first-class fruit. But the grower, who was a practical man, had found that they afforded but an insignificant return, while an adjacent area under fruit trees of the citrus order gave handsome profits. The reason, he declared, lay in his distance from the state capital and the rapidity with which soft fruits spoiled in the hot summer. These are difficulties that will be obviated with the further settlement and development of the country, but in the mean time, they scarcely serve to explain why Australia, with its remarkable capacity for growing fruits of all kinds, should be an importer instead of an exporter of dried and preserved fruits.

This is but one example of many industries that are languishing, although possessing possibilities that have been proved beyond any question. The future of many of them - and especially those of Northern Australia-is inextricably in- 
volved with the question of coloured labour, against the employment of which Australia has definitely decided, at least, for the present. The experiment, described in another chapter, of deporting the Kanaka labourers from the sugar fields, and substituting white labourers in their place, will be watched with the keenest interest throughout Australia. Should it succeed, it will be argued that cotton and other products can be cultivated without the coolie labour for want of which, according to the advocates of coloured labour, these industries are at present neglected.

There are other possibilities, however, which long ago commended themselves to the notice of Australian politicians. The position assigned to the Colonies in the present scheme of the British Empire would appear to be that of producers of raw material, and consumers of the manufactured articles of the Motherland. Proposals for strengthening the links of Empire on the basis of trade are founded on these relations, and, without the principle having been accepted, have encountered obstacles arising from the unwillingness of the Colonies to accept the minor part thus assigned to them. If the use of the word "colony" implies a place entirely given up to the primary industries, then "Once a colony, always a colony" is an axiom that must not be too readily accepted. If the United States of America were still an integral part of the British Empire, it would hardly be possible to refer to them in their present stage 
of development as "our American colonies." It is quite certain that Australia looks forward to the day when certain of its raw materials, such as wool and leather, will be manufactured in Australian factories. With this end in view, quite early in the history of responsible government in Australia, some of the states began by imposing customs duties designed to protect local industries, and the present Commonwealth Tariff, while framed partly for revenue purposes, is also in some measure a protective tariff.

The industries created and fostered in this way have had to contend with difficulties arising from a want of uniformity in the tariff of the different states, and from the tariff war the states waged against one another before the Federal era.

Their expansion has been more definitely affected by the determination of the Australian Labour party to preserve the favourable conditions under which the city worker exists. The industrial legislation of Australia is designed to maintain high wages and short hours of labour, and under these conditions it is possible that the amount of protection afforded by the present tariff does not give the manufacturer sufficient encouragement. In any case, the dictum of Mr. Coghlan, the leading authority upon Australian statistics, is that "progress of the manufacturing industry in Australasia has been very irregular, even in the most advanced states." 
The broad principles of Australian industrial legislation-for the details vary in the different states-are extremely favourable to the worker. Short hours are secured by the provision of an eight-hour day in workshops and factories, and by Acts insisting on the early closing of shops, and the observance of a weekly half-holiday. The rate of wages is maintained either by a Factories Act, which provides for the establishment of Boards to fix a minimum wage for each class of labour, or of Arbitration and Conciliation Acts, designed to settle disputes between Capital and Labour. An instance of the working of the Arbitration Act in force in New South Wales may be of interest. The men engaged in the coal mines at Newcastle and in the neighbourhood of that city, some four thousand in number, had a difference with the mine-owners on the subject of the rates for hewing coal. By common consent, the dispute was referred to the Arbitration Court, and, in this case, the decision of the Court was favourable to the masters rather than the men. Most of the men went on with their work without interruption, but in one mine, it was decided to defy the Court and cease work. The mine-owner then appealed to the Court to enforce its decision, and found that it was powerless to do so, although the owner might have been heavily fined had he refused to obey the ruling given. Proceedings to punish the men were then taken in another Court, but in the meantime, chilled by the open 
disapproval of their fellows elsewhere, they retreated from their position and resumed work.

These Arbitration courts are gradually establishing definite rates of pay in most employments, and further legislation provides that these rates shall not be lowered by the introduction of cheaper labour from outside. The Immigration Act of the Commonwealth Parliament, for instance, provides for the exclusion of coloured labour, and of contract labourers as well. Attention was drawn to this by the notorious case of six hatters, who were subjected to the interrogation of the authorities before being allowed to enter Australia. It was made clear at the time that it was possible for white British subjects to be excluded from the Commonwealth if they entered into a contract with their employers before reaching Australia, and the fact was eagerly seized and used as a basis of attack upon the Government responsible for such legislation. The wrongs of the six hatters were discussed in both the English and the Australian Press, and inspired many a spirited Opposition assault in the Commonwealth Parliament.

Meanwhile, the six hatters themselves had settled down comfortably in Sydney, and proved in due time that, once having obtained admission into Australia, they were fully contented with its industrial legislation.

The occasion occurred at the general election of 1903, when Mr. G. R. Reid, the Opposition 


\section{Farm and Factory}

leader, contested the seat of East Sydney. Mr. Reid had made full use of the six-hatters episode throughout the session of Parliament, and by a curious coincidence found the six dwelling in his own constituency. Moreover, they were all on the committee of the Labour candidate who opposed Mr. Reid, and who was heart and soul in favour of the legislation by which they might easily have been excluded from Australia. This conclusion to a much discussed episode is recounted as affording proof of the one certain result of the experimental legislation now on its trial in Australia. The workman, at any rate, is reasonably contented with it, as, indeed, he has every reason to be.

It is never safe, however, to argue $a$ priori about Australian affairs. The statistician who predicted an Australian population of 5,678,000 for the year I9or had no prevision of the ten years of stagnation that almost immediately followed his prophecy. The return of normal and favourable climatic conditions will afford the observer a better chance of determining whether the country can support manufactures hampered, as far as outside competition is concerned, by industrial legislation so favourable to the workers.

A more immediate issue may be found in the policy now being initiated by the Government, of attracting population to the vacant lands of Australia. This policy implies the throwing open of areas of land suitable, by reason of soil and 
climate, for immediate settlement, the opening up of fresh markets for Australian produce in other parts of the Empire and in foreign countries, and a larger measure of encouragement to the man upon the land. It further implies the construction of railways designed, not for the benefit of one capital city, but for the utmost development of the districts through which they pass; it involves the conservation of the invaluable water that now runs to waste; and it points to the stern discouragement of the professional unemployed of the Australian cities. It reads like a broad national policy, born of recognition of errors in the past, and consistent with the national ideals of which so much was heard during the first few days of the present century. It is a case of farm versus factory, and the present trend of Australian opinion seems to be strongly in favour of farm first, and factory afterwards.

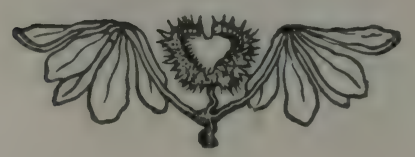




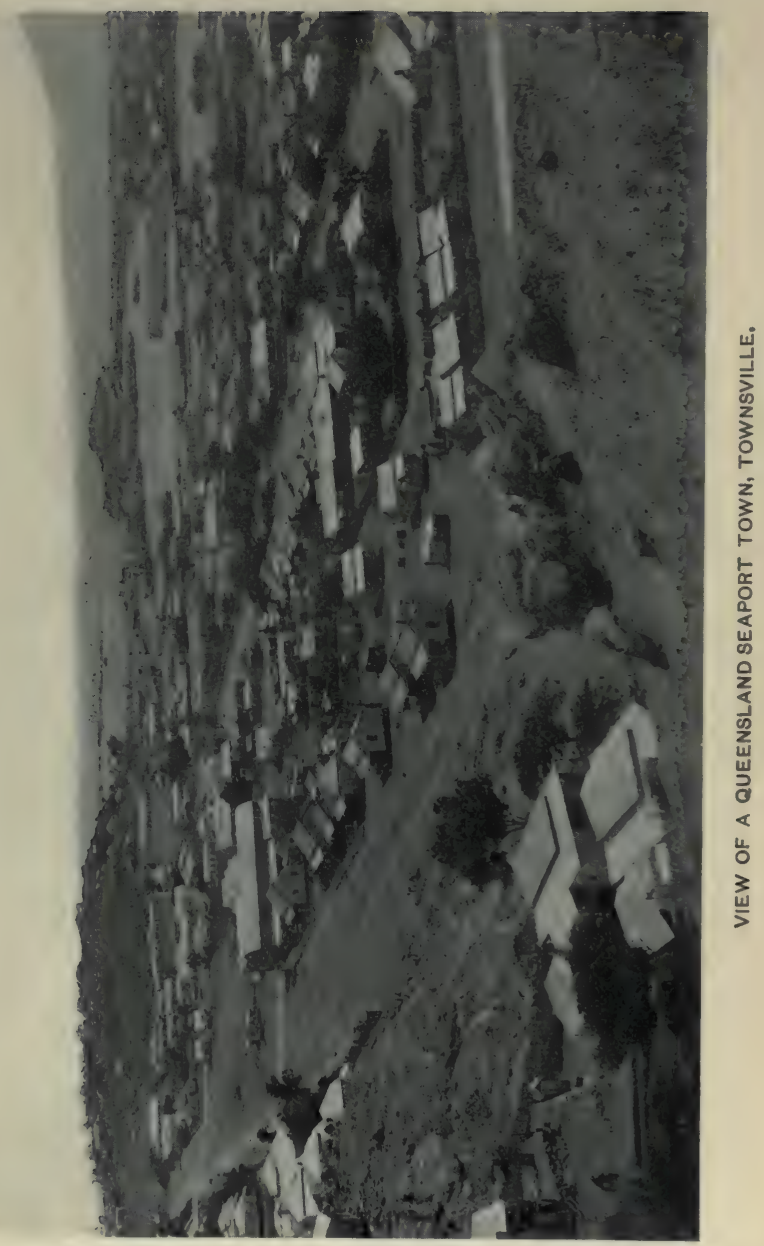





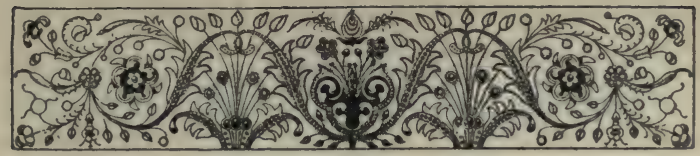

\section{CHAPTER XIII}

\section{THE AUSTRALIAN WOMAN}

THE ups and downs of Australian life have forced upon the Australian woman very many different parts in life. Fifty years ago, upon the goldfields at least, woman occupied the position which Mr. Bret Harte has so aptly pictured in his stores of the Pacific Slope. The few women upon the goldfields were made the objects of a chivalrous admiration that was not without its humorous side. I have often heard a ladyshe is a very old lady now-describe her first appearance in one of the more prosperous mining camps. As she walked from the coach to her husband's tent, her uplifted skirts displaying a stout pair of Wellington boots prudently worn as some protection against the slengts of mud and clay through which she had to struggle, the camp resounded with cries of "Jo, Jo," and ten thousand jolly miners threw down picks and dishes to gaze at the novel sight of a woman. For months, she was the heroine of that out of the way camp, the miners resorting to all sorts of novel expedients to procure her some delicacy 


\section{I58 Australian Life}

or comfort, which was tactfully offered as a tribute to her femininity. The ideals of those good days are fortunately not dead, but the conditions of Australian life are variable in the extreme, and the position of woman in the Australian cosmos has varied with them. In the flood-tide of prosperity, the Australian showed a tendency to treat his womankind as the American is said to treat his: to isolate them from every care of business and even of household management. The Australian woman had good times then, but not at the expense of her home life, and she showed in the crash that followed that she possessed the resourcefulness and courage which is a mark of Australian character. Australians have good reason to be proud of the manner in which many of their women, born and educated amidst surroundings of comfort and luxury, set to work at a moment's notice, when, by an unexpected turn of fortune's wheel, their fathers and husbands were stripped of their wealth, and hampered by a very general business depression throughout Australia.

Visitors to Australia have been unanimous in recording the marked difference in type of the Australian woman, for she has adapted herself more readily to the changed conditions of life and climate than the Australian man. Her dress, although following the standard of fashion imposed upon her by Parisian and London authority, is modified so as to suit the bright light and 
cloudless blue skies of her surroundings. Nothing is more charming on an Australian holiday than the cheerful effect of the bright but cool and appropriate dresses of the daughters of the people. In the clear sunlight and against the sombre foliage of the trees and shrubs, it becomes at once apparent that the genius of the Australian woman has solved the question of dress, while the halting instinct of man is only beginning to rebel against the conventions imposed upon him by his Old World ancestors. The same genius is shown by' the woman in the management of her house; if allowed her own way, the furnishings are designed for coolness and airiness, no trouble is spared during the glaring daytime to expel the light and the flies, and her own regimen of diet is rapidly approaching that which is natural and healthful in such a climate. It is the Australian custom that pleasure shall mainly be taken out of doors, and to this rule, the Australian woman has not been slow to conform. But there has never been any craze for undue athleticism among the Australian girls, many of whom learn to swim and to ride as a matter of course, leaving the more competitive pastimes to their brothers. It is true that there have been teams of lady cricketers, who enlivened the rather dull life of their rival country townships by matches which attracted considerable attention. The fact that the attention was attracted proves that the incident was a rare one, and up to the present, the Australian girl has 
been content with those pastimes, such as tennis and golf, which have always been considered womanly. But she revels in the less active open air entertainment provided by picnics, garden parties, boating excursions, and open-air concerts, and the frequency of these gives to her intercourse with the other sex a frankness and freedom from restraint which is one of her special charms. The camaraderie between the sexes, and the free use of Christian names, is at first disconcerting to the new arrival, who may be apt to misconstrue the free-and-easiness of the Australian girl and to be snubbed accordingly.

Among the troubles of the household life in Australia, the servant difficulty is not the least, and this presses most heavily upon the woman. The best servants obtainable are those from the bush, who, although rough diamonds at the outset, have the qualities of diligence, quickness, and extreme good nature. They have also the Australian characteristic of independence in a marked degree, and the national love of holiday-making and of celebrating anniversaries. Every housewife in Australia is familiar with the sinking sensation experienced on learning that "her treasure," carefully trained through twelve months of awkwardness or ignorance to something like aptitude, intends to take a holiday from Christmas Eve to New Year's Day. Remonstrance is useless. "My mother wants me at home," is the only explanation vouchsafed of this base de- 


\section{The Australian Woman I6I}

sertion, and there is nothing for it but to submit. The best way out of the difficulty is that frequently followed in Australia. The Christmas season is chosen for the annual holiday to the seaside or into the country, and the home is locked up for the occasion. Thus Mary Jane is allowed to enjoy her Christmas at home, and repays by a patient and good-tempered service and a willingness for work of all kinds which could not be demanded from the highly-trained British domestic.

The critics of the Australian woman-and there have been many-have complained that she both walks and talks badly. For the first charge, there would seem to be less foundation than for the second; for, although the ordinary observer would fail to notice any lack of grace in the carriage of the women in the cities, the presence of an accent is too obvious to be overlooked. The theory that the hardening and distorting of vowel sounds so common in Australia can be traced to the State schools has been advanced. Those who support this contention point to the large classes common in these establishments, and to the monotonous repetitions in chorus that constitute part of the system of teaching. If this theory be a correct one, the system cannot be amended too quickly, for the accent itself is a sad drawback to the pleasure afforded by the clear and musical voice that is a characteristic of the Australian woman.

A more serious matter is the decline of the 
Australian birth-rate, noticeable during the latter part of the nineteenth century, pointing as it does to a corresponding decline in the physical or moral fibre of the Australian woman. Mr. Coghlan, the statistician whose paper upon the subject first called public attention to this development of Australian life, decided as a result of his early investigations that Australian-born women do not bear so many children as the European women who emigrate to Australia. Fuller inquiry, however, convinced him that in this conclusion he had been mistaken. The decline of the birth-rate is more intimately connected with the rapid growth of the capital cities, where the conditions of life approximate more closely to those of the Old World. Mr. Coghlan's carefully reasoned paper upon the subject has resulted in the appointment of a commission, empowered to inquire fully into all the circumstances affecting this phase of Australian life.

Among the most prominent characteristics of the Australian woman is her talent for music, amounting in many instances to positive genius. This statement is not made merely because Australia has given to the world singers who, like Madame Melba, unite the highest artistic instinct with the most remarkable natural gifts, and have so become famous. It is rather because, go where you will in Australia, you will hear good voices, used with instinctive art, and instruments played, even where skilled instruction is lacking, with 
sympathetic and just perception of the meaning of the music. From the singing of the church choir in the little back blocks township to the concert given by the pupils of the musical conservatorium of the capital, there is everywhere abundant evidence that Australians have not only a true love for music, but the gift of musical expression. The eagerness in grasping any means of improved cultivation and knowledge is proof of this, as well as the enthusiasm with which skilled performers are welcomed and heard. Music is the one art that has received genuine and notable encouragement in Australia.

The Australian woman who earns her own living has had to encounter less prejudice and opposition than has been the case elsewhere. In the professional class, women have come rapidly to the front, and women doctors, dentists, and lecturers are matters of everyday existence, being accepted as readily as their male counterparts. One Australian capital possesses a lady, who, having developed marked business ability as a house and land agent, applied for and obtained an auctioneer's license. Her sales are conducted with a promptness and readiness of which any male auctioneer might well be proud, and her repartees to interrupters at the outset of her career were peculiarly crushing. In the financial crisis following the period of over-speculation in land there were many examples of young ladies who devised novel and useful methods of replacing 
vanished incomes. One result of that episode in Australian history is the air of pleasant refinement that distinguishes the Australian tea-room from similar establishments elsewhere. The condition of the working-women of the poorer classes, unfortunately, leaves much to be desired. In some employments, they have reaped the benefits of the organisation and political power wielded by men, but in other of the avocations peculiar to the working-woman alone, their position is not as advanced as that of the Australian worker generally. The sweater exists in Australia as elsewhere, and finds his victims, as elsewhere, among those who are poorest and least able to protect themselves.

This state of affairs may possibly be remedied by the exercise of the franchise now conferred upon the Australian woman. The woman voter is, of course, no new thing in Australasia, for both in New Zealand and South Australia, the women have for some years held equal electoral privileges with the men. But the granting of the Commonwealth franchise to the Australian woman was an experiment on a much larger scale, and has resulted in some developments of a most interesting nature. It has been found that the women voters outnumbered the men in the Commonwealth, although the majority of women is not a very large one. The woman's vote is, therefore, a very important consideration for the politician, who is alive to the experience already 


\section{The Australian Woman 165}

gained of its effect in New Zealand. In that Colony, it has been found that the one political question of absorbing interest to the feminine mind is the regulation and control of the traffic in intoxicating liquors. It is significant that with the approach of the first general election at which the woman's franchise was exercised, those interested in this trade formed associations designed for meeting the would-be reformers halfway, and for improving the conditions under which intoxicants are sold in Australia.

The franchise itself was received by the women with a due sense of the importance of the gift. The more advanced formed political associations, devised an election programme, and actually nominated women candidates for positions in the Australian Senate. There are also associations of women who hold that the time for woman's representation is not yet ripe, although taking an active and intelligent interest in the current political topics. Frequent meetings were organised, at which addresses of an explanatory nature were delivered by Australian public men, with the view of educating their hearers upon the unfamiliar topic of politics. Three women allowed themselves to be nominated for seats in the Australian Senate, but none of them were successful, the polling disclosing the curious fact that they obtained more support from male voters than from those of their own sex. The result of this first election at which woman's suffrage was exercised 
throughout Australia afforded little justification for the fears entertained by those who opposed the granting of woman's suffrage. For the present, the Australian woman is content to be guided in the main by the political opinions of her husband or brother.

It is one of the accepted doctrines of the Australian bushman that "the bush is no place for a woman," but it frequently happens that the same bushman marries and settles down to make a home in the bush. The settler's life presses more hardly upon the woman than the man, with the result that the first impression gained of the women of the bush is one of sallow complexions deprived of all their freshness by the burning sun, and of worn faces marked with premature lines by care and waiting. More lasting, however, is the remembrance of their simple goodwill and kindly hospitality to strangers, their mutual helpfulness at all times, and their courage and resourcefulness in the desperate expedients to which they are sometimes turned by the loneliness and isolation of bush life. Every little settlement has its tale of woman's heroism, told, and then quite as a matter of course, only in response to the most persistent questioning. The story of the woman who maintains and keeps together the little bush home when necessity forces the man to seek em. ployment somewhere in the wide emptiness of pastoral Australia, is but an everyday incident, for there is no finer thing in all Australia than 


\section{The Australian Woman}

the noble, self-denying lives of many of these bush women.

The bush affords many instances of women who, under stress of circumstances, have played strange parts in life. There are authenticated accounts of women tramping the country in men's attire, carrying their swags and turning their hands to all the varied employments required of the handy-man of the bush. It is not many years ago since there died a woman known on the Australian roads as "Bullocky Mary." In short skirts and heavy boots, with a man's felt hat upon her head, this Amazon used to drive her team of bullocks through the country, lashing them with her long whip and a vocabulary of the most effective description. The spectacle of husband and wife mining together is by no means an uncommon one, the man working below in the mine, while the woman turns the windlass which lifts the débris from the shaft. Australian racecourses have known at least one woman who trained her own race-horse, and more than one woman who plied the calling of a book-maker.

This aspect of feminine life is fortunately growing more uncommon as time goes on, and it is easily possible to discern the true place of the Australian woman by looking in exactly the opposite direction. The proportion of women students at the Australian universities is steadily increasing, and it appears from the reports of these institutions, that woman is less apt than 
man to regard the higher education as merely a means to an end. Many of the women's clubs have a literary and an artistic basis, and it seems very probable that the Australian woman will play an important part in preserving the race from the commercialism which is at present so noticeable among the men of the cities.

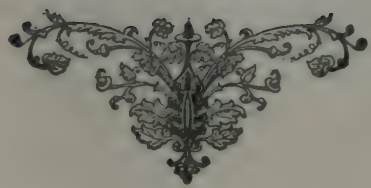




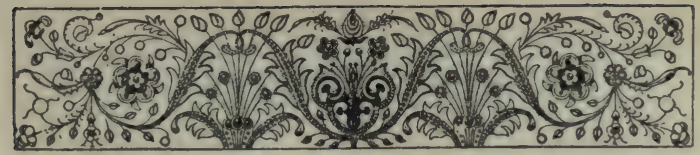

\section{CHAPTER XIV}

\section{HOME AND SOCIAL LIFE}

THE complaint that the Australians are abandoning the pleasant home life of their fathers is not unfrequently heard from the older generation in Australia, and especially from those of British birth. The rigorous British winter, that casts a halo of attraction around the family circle gathered about the fireside, has no place in the experience of young Australia. Inclination conduces to less time being spent indoors and more in the open air. For the greater part of the year, the beaches, parks, and streets of the cities are thronged in the evenings with promenaders, chatting and laughing gaily in the enjoyment of the pleasant coolness that comes after suuset. It may be possible that the intimacy of family life is weakened by this devotion to outdoor recreation, but it is not easy to discern any marked difference between the home life of the Australians of the cities and that of people in a similar sphere of life in Great Britain.

In the bush, however, the absence of any attempt to make home attractive is readily 
noticeable. The primitive discomfort that was unavoidable during the early pioneer work of the settler, often clings to his habitation when the necessity for it has ceased to exist. The endurance of inconveniences and makeshifts becomes a habit, and money that might well be spent on home comforts and necessities is laid out on improvements to the land, or saved against the bad times for which the people of the bush are prepared by the uncertain conditions of their life. Brought up amid these surroundings, the younger generation has learned the lesson of doing without things, and perpetuated the custom. The unloveliness of the bush house, its unfinished aspect, and its want of any homelike appearance are only too noticeable. The crowded capital cities are a standing proof of the distaste of the people for life on the land, and there can be no doubt that at present it is rendered more unattractive for the younger folk by the extent to which comfort and convenience are subordinated.

As a rule, the Australian is content with three meals a day, and has meat at every meal. The working-man will breakfast on chops or steak, and at midday, if unable to go home, may patronise a restaurant, where a plentiful dinner costs him sixpence. At six o'clock, he has a substantial tea, with cold or hot meat, and very wisely dispenses with supper. At every meal, he probably drinks two or three large cups of tea, and appears little worse for it. London 


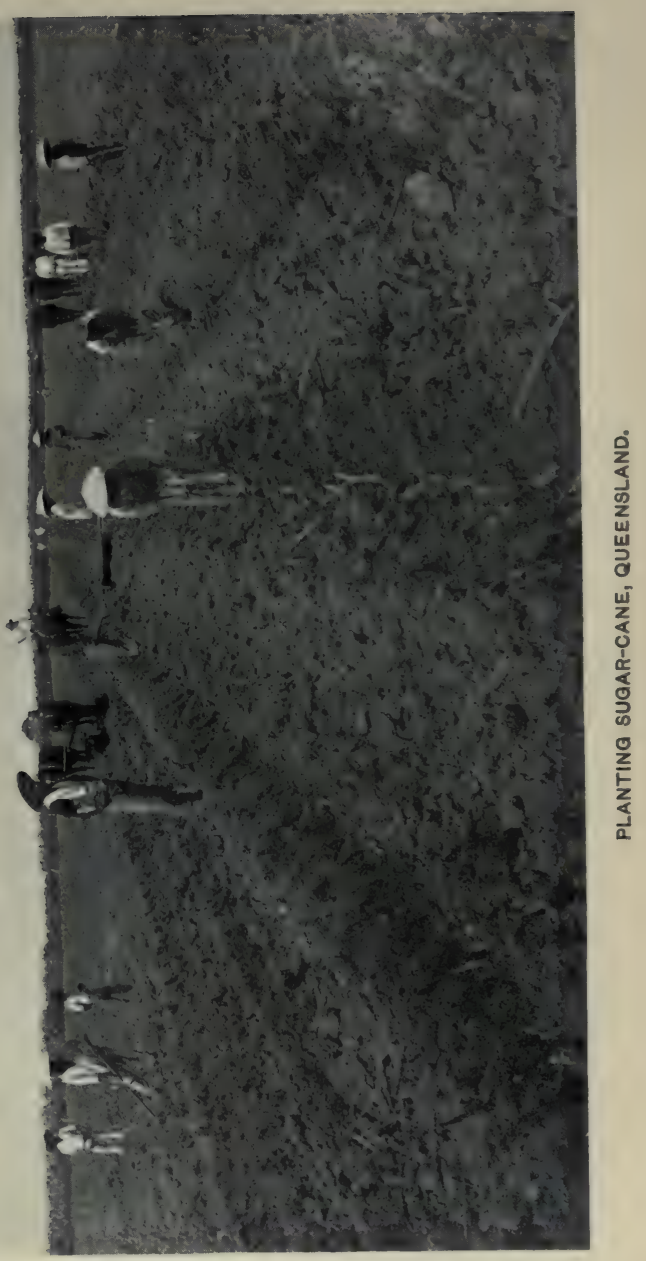



clerks and employees in business houses usually take a cup of tea between four and five in the afternoon, and supper in the evening. In Australia, city workers lunch in the middle of the day, and are able to reach their homes in time for a dinner at six o'clock, so that they have little time or inclination for the afternoon break. The professional and upper middle classes dine a little later, as a rule, and the cup of afternoon tea may or may not be taken; but, in Australia, afternoon tea is recognised as more exclusively a feminine privilege.

The large amount of meat eaten by the Australians is due, in a great measure, to the cheapness of that commodity. Statistics are rarely interesting, but it is surprising to learn that each Australian consumes two hundred and sixty-four pounds of meat annually, as against one hundred and nine pounds eaten by the average Briton, and seventy-seven pounds by the Frenchman. During recent years, however, there is a noticeable tendency among Australians to eat less meat, and more of the abundant fresh fruit. Most Australian doctors advise a breakfast of fruit, followed by toast and coffee, in the place of the meat and tea of the old Australian régime, as being more in keeping with the Australian climate. In the cities, this advice begins to be followed, but the bush remains faithful to the fried chops and steaks which have always constituted its staple fare. The monotony of this meat diet cannot 


\section{2 \\ Australian Life}

fail to impress itself upon any one who has been called upon to endure it for long, and is all the more remarkable because so many circumstances exist in Australia favourable to its inexpensive variation.

If blazing fires and draught-proof rooms are not essential to the comfort of the Australian home, it is at least necessary to resort to expedients to counteract the effect of the burning summer suns. Many Australian houses have their roofs coated with white paint, because that colour attracts the rays of the sunlight least readily, and are screened on all sides with thick roller blinds made of strips of bamboo. Devices for excluding dust and flies, while admitting the cool evening air, are generally used, and in the middle and northern parts of Australia, beds are customarily furnished with mosquito nettings. In a wellappointed Australian house, an ice-chest is a necessity rather than a luxury, for in this way only can the drinking water be kept cool and the butter set upon the table in a state of solidity. The ice-cart goes from door to door as regularly as the milk-cart, throughout almost the whole of the year. Finally, the Australian of the cities does not consider a house fit for human habitation unless it contains a bathroom and shower-bath, and this statement holds good with every class of Australian society.

With these modifications, the Australian continues to cherish the home ideals just as the 


\section{Home and Social Life}

Briton does his. It is an airier home, not so crowded with cherished pieces of furniture, and not regarded so much as a refuge from the rigours of the world outside. It is a home of open doors and windows, with a wide veranda, where indoor life meets the open air existence on terms of happy compromise. By imperceptible degrees, the Australian home is adjusting itself to the Australian climate.

The belief in the absence of class distinctions in Australia is cherished by the masses in the face of an existing class. But the man who rises from the masses is quickly made aware of an exclusive circle of people " in society," and of the efforts made to reserve such privileges as this circle may enjoy. Australian society and the struggle made to maintain class distinctions have furnished the theme for many satires. It is, indeed, easier to ridicule than to adequately describe the basis of Australian society. Let it be premised that the most important, if not the most exclusive, social entertainments are those offered by the Australian Governors in their capacity as representatives of the Crown. At such entertainments, the most prominent people are those who have made their way to the front in politics, professional life, commerce, or pastoral pursuits. Many of them, by their education and upbringing, or by their natural qualities, are well fitted to adorn any society, but there are some of whom it may be said, without any unkindness, that 
they are quite at their worst in the atmosphere of the court and ballroom.

The social duties of an Australian Governor are obviously of a very exacting nature, since in his hands is placed the task of reconciling the claims of so many social aspirants, and of keeping Government House free from the invasions of enterprising people whom those already within the pale would consider impossible. The newly arrived Governor accordingly provides a book in which callers may write their names and addresses, and from this book is compiled the list of those who are subsequently entertained by the vice-royalty. I do not profess any ability to indicate the lines upon which the selection is made, but it is no secret that the path of the Australian Governor who has not a well-posted secretary and a staff of tactful aide-de-camps is by no means a pleasant one. These Government House entertainments are interesting. The central figure is that of a tactful and courteous gentleman, who, with the assistance of an altogether charming wife, and a band of boredlooking aides, is cordially receiving an immense number of guests, some of whom regard his hospitality as a right. As they arrive, the guests fall naturally into sets: the political set, including a number of the higher officials; the landowning set, descended from the Australian wool-kings; the professional and military set, including many worthy gentlemen in expensive 


\section{Home and Social Life}

military uniforms; the newly moneyed set, casting a suspicious eye upon the latest recruits to their ranks. There is, in addition, a large number of pleasant people who have come for the sole purpose of enjoying themselves, and set about doing so very naturally and thoroughly.

There is, further, an inner circle of Australian society, whose doings are chronicled with great exactness and intimacy by the society papers. For obvious reasons, no attempt is made at a rigid definition of this circle of "the very nicest," for that would defeat the end for which the society paper exists. One gathers that its ideals are drawn from high life elsewhere, and that a close acquaintance is maintained with the latest movements and customs of the best English society. It may be urged, with some truth, that no better model could be taken, but it has resulted, rather unfortunately, in the permanent transfer to England of some of the people and much of the money that Australia can ill spare.

There are, naturally, thousands of refined and well-bred people, for whom neither the exclusiveness of this circle of "the very nicest," nor the entry to Government House and the social cachet it is supposed to give, have any special attraction. To outline their social life would be but to describe the ordinary existence of the educated Anglo-Saxon middle class everywhere. Formalities and conventions may be slightly modified, but they are by no means dispensed with entirely. 
In this respect, the lot of those in the lower grades of the official class, and of the ordinary clerk, is perhaps less to be envied than that of any other class in Australian society. The incidence of the Australian protective tariff, and the high scale of professional fees of all kinds, make any attempt at keeping up appearance one long struggle. The working-man, who is more highly paid than the clerk and the subordinate public servant, is much better off, and, by frankly disregarding the distinctions these others must observe, can obtain a far greater share of the desirable things of Australian life. Owing to the heavy protective duty on clothing of all kinds, the clerk and the shop-assistant are, in proportion to their earnings, the most heavily taxed classes in the whole Australian community, although the higher rates of remuneration obtained in other employment do not hold in these occupations.

As for the working-man, he is little troubled by social distinctions of any kind. His relations with his employer do not call for any show of deference, his political representatives see that his necessities shall not contribute too largely to the revenue, and his main concerns are family affairs, politics, and sports. His interest in politics occasionally brings him into touch with the movements of "society," after a fashion that rouses a curious resentment in him. It will be difficult for any one who has never lived in Aus- 


\section{Home and Social Life}

tralia to understand how keenly the people dislike the acceptance by one of their popular politicians of the knighthood and decoration sometimes proffered as an honour by the Im. perial Government. The Australian politician who refuses such honours, renews the trust of the people in himself, and incidentally deprives his wife of an attribute of a mean value in society. The covert antipathy that exists between masses and classes is illustrated by this society approval of what the people condemns. The reasoned objection to the bestowal of titles upon Australians is that it is at once unnecessary, and anti-Australian, and the most national in spirit of all Australian papers wrote seriously of it that "Australia took up the Cross of the Order of St. Michael and St. George on its shoulders to march towards the crucifixion of its national life." It should be borne in mind that the whole of the resentment excited by the bestowal of these honours is directed against the recipient, and that the offer of them is recognised in the spirit in which it is made.

Clubs in Australia are few, but, as a rule, they are very good. Each of the capital cities possesses at least one club managed on lines as constitutionally exclusive as any that London can boast. An extreme conservatism is one of the products of the ferment of an ultra democratic community, and in his club, the Australian Conservative finds a congenial atmosphere free from the Radicalism 


\section{Australian Life}

that disturbs him everywhere else. Their membership is almost exclusively confined to the squatters, mine owners, and property owners, who find themselves, by sheer force of circumstances, in direct opposition to the socialistic spirit that pervades the working classes. Other clubs are founded on an artistic or literary basis, but the average Australian, who cannot be considered a club man in the English sense of the word, is usually content with his suburban club, with its tennis-lawns, bowling-greens, and modest card and billiard rooms. Throughout Australia, the sporting and recreation club flourishes exceedingly, but the political club, so dear to the British tradesman and artisan, is an unknown thing. Its place, however, is more than taken by such organisations as the Australian Natives' Association, some account of which is given in another chapter.

The social life of the bush, based on the general foundation of comradeship and mutual helpfulness, is grandly simple in principle. Men undertake for one another obligations not recognised in other communities, and rely upon one another in a spirit of trust that is marvellously justified. By this rule of the bush, the population of a whole district sets itself to scour the country for days in search of a lost child, and the same rule makes it possible for a bushman to travel on foot throughout Australia without a shilling in his pocket. Life in the bush is hard and monoton- 


\section{Home and Social Life}

ous, and sometimes breeds bitter senseless feuds and stupid misunderstandings. But in time of trouble or loss, fancied slights and ancient grudges are forgotten, and the sufferer experiences only the full and practical sympathy of his neighbours. The traditional hospitality of Australia is the hospitality of the bush, extended without a second thought to acquaintance and stranger alike, and accepted in the same unquestioning spirit. "I have ridden," writes Sir Gilbert Parker, "to a plantation late at night, turned my horse into the horse paddock, entered the house, struck a match, found a sofa, lain down, and waked in the morning to find life bustling about me, my breakfast ready on the table, and I an utter stranger! . . They appreciated the desire on my part not to disturb their rest, and they apologised for the hardness of the sofa."

The social code of the bush is summed up by Mr. Henry Lawson in one brief sentence: "Drunk or sober, mad or sane, good or bad, it is n't bush religion to desert a mate in a hole." And among all bushmen there is an acknowledged mateship.

City and bush meet in the country townships, where neither shows to any great advantage. To begin with, the township, whether new or old, is invariably unlovely. A wide street of straggling, iron-roofed houses, a hotel or two and a few stores, at least two churches and a school, each building as monotonously unsightly as its 
neighbours - these are the township's main constitutents. Local society consists of the bank manager, doctor, clergyman, and a few others, with lower positions assigned to the school-teacher and police-constable, the latter usually a superior man and invariably an influential one. This circle is regarded as consisting of city folk, and is viewed with distrust and suspicion by the locals. The feuds and scandals inevitable in village life are embittered by this jarring of town and bush, and to the policeman, if he is tactful, falls the task of keeping peace between the parties.

The visitor who studies the life of Australia in a bush township can hardly escape the conclusion that this must be among the least sober of all countries of the world. The conclusion would be an erroneous one, as statistics will prove, but there is no doubt about the amount of hard drinking that goes on in the bush townships. There may be seen the bushman, who has not known the taste of intoxicating drink for months, indulging in an orgy in which he invites all comers to participate. The occasional "bursts" of more frequent visitors to the place are equally obvious, for the little township concentrates the drunkenness of a whole district. The moral fibre of the young man called upon to live in such surroundings, perhaps as bank clerk, or civil servant, must be stout, or he will run considerable danger of yielding to the infectious atmosphere. Life in the bush township is supremely dull, 
especially to a youngster who has newly abandoned the attractions of a big city, and the one spot less boresome than the rest is the hotel parlour. It is recognised in Australia that young men who would remain steady in other surroundings are apt to acquire intemperate habits during a period of township life.

It is not an attractive picture, although, unfortunately, it has its counterpart in other countries. Years go by and bring little change to the dull hamlet, with its single dusty street and its general unfinished air of rusty untidiness. The railway comes, and the one event of the day is the arrival of the up-train, just as the one topic of conversation is the latest aspect of the perennial quarrel between the bank manager and the publican.

Dingo Bill arrives from " way back" and paints the place red, until his career is cut short by the constable, after which the doctor treats him for delirium tremens, and he departs, penniless, but satisfied. Once a year comes the show, or the sports, followed by drinking, fighting, and a general scene of licentiousness and disrepute. It is Australian life at its worst: worse than the life of the big cities, and infinitely worse than the brave struggle on the lonely selection. 


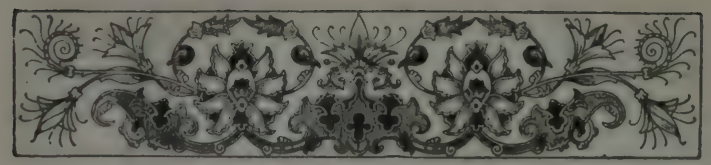

\section{CHAPTER XV}

\section{THE AUSTRALIAN A'T PLAY}

$\Lambda \mathrm{S}$ might be expected from a people which $A$ allots eight hours out of the twenty-four to recreation, the Australians are devoted to outdoor sports of all kinds. The climate assures so large a proportion of fine days, the cities have been provided so liberally with playing-grounds, and the hours of labour are so short, that it could hardly be otherwise. As a result, the Australian is sometimes reproached with devoting too much time to play, though there is something to be said in favour of a national sentiment which regards it as a matter of course that every young man shall be able to swim, to ride a horse, and to handle a gun or a rifle. The president of an Australian Science Congress recently proposedno doubt jocularly-that research should be initiated to the end that the bacillus of sport might be eradicated from the rising generation; but Australians are not able to forget that a full recognition of their existence was first obtained in the Motherland by the success of their bands of cricketers. 


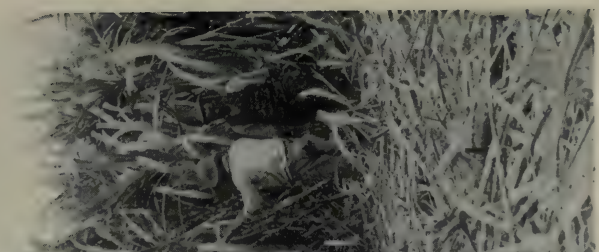

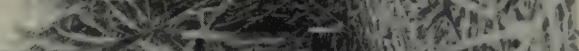

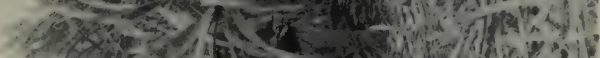

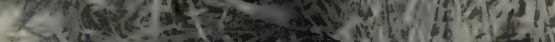

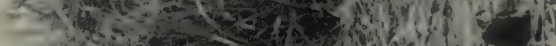

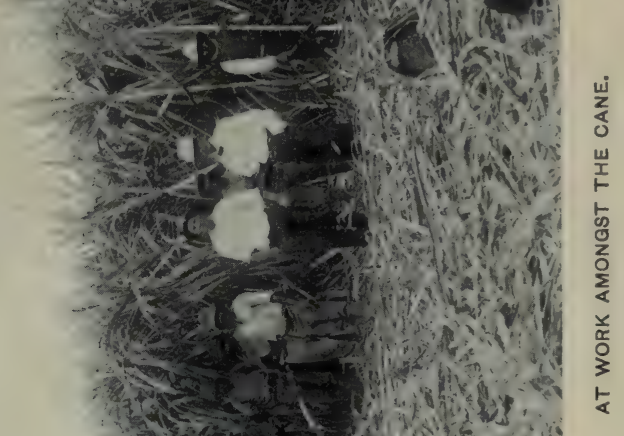



It has been said that when an Australian settlement is planted, the first care of the pioneers is to mark out the site of the cemetery, the second to plan a race-course. Horse-racing in Australia, however, is not the constant and absorbing pursuit made of it by its devotees in Great Britain, but an amusement that concentrates public attention during certain seasons of the year. For a week, it becomes a consideration and is made a leading topic of conversation, and then little is heard of the subject until another racing carnival comes round. During the first week in each November, for instance, the city of Melbourne is devoted to horse-racing; for the Melbourne Cup, the most important event in the Australian racing calendar, is then decided. It is remarkable how many gatherings, necessitating the presence of visitors from other states, are held in Melbourne at that season. The Australian fleet of warships, usually stationed at Sydney, may invariably be found in Port Philip, and from all corners of the continent, visitors find their way to Melbourne for the great Australian reunion. Bronzed squatters from Queensland, lean prospectors from the sands of Western Australia, and traders who have exhausted all the possibilities of the South Sea Islands, may be seen renewing old acquaintance on the spacious lawns of the Flemington racecourse. Everybody is there, from the GovernorGeneral to the newest music-hall favourite. People who would not entertain the idea of 


\section{$184 \quad$ Australian Life}

attending any other race meeting, find their way to the course on Melbourne Cup Day. The Australian spring is in its most winsome mood, and as fashion has decreed that this shall be the occasion when the Australian woman may display her most tasteful dress and most expensive hat, the scene on the great lawn before the grandstand becomes the most brilliant to be witnessed in all Australia.

On a big hill behind the grand-stand are the Australian workmen in their thousands, and the hoarse roar of the bookmakers in that part of the race-course is loud and continuous. Half a crown admits to this enclosure, attached to which is a large paddock where wives and families may picnic in comfort. Admission to the area enclosed by the race-course itself is free, and here, too, is a dense crowd, enjoying all the shows and amusements usually seen at a fair. As many as a hundred thousand people have been present on the course to see the race for the cup, and the day is observed as a public holiday in the city. But the interest in the race is not confined to those upon the course. For five shillings, a ticket may be purchased in a cup lottery, and the fortunate drawer of the winning horse learns from the result of the race that he has suddenly stepped into a fortune. The promoter of these lotteries deducts ten per cent. of the money passing through his hand, amounting annually to some hundreds of thousands sterling. Clerks 


\section{The Australian at Play}

185

and shop girls set aside a small portion of their earnings each week, forming speculative companies to send regularly for tickets and divide any winnings accruing to them. Apart from these "consultations," as they are called, there is a great deal of betting upon the result of the race, which usually attracts a field of about thirty of the finest horses in Australia.

When this field of horses faces the barrier of the starting-gate, there is a sudden hush over all the course. The promenade on the lawn stops for the time, and every one seeks some point from which the race can be viewed. The roar on the hill ceases, the swing-boats and merry-go-rounds are still, while all prepare to watch the struggle. In five minutes, the result will be telegraphed to every town through a continent of three million miles, huge sums of money will have changed hands, a few fortunate ones will have become suddenly rich, and many thousands disappointed. Three minutes of breathless suspense, a mighty roar as the struggling horses flash past the winning-post, and then the great crowd settles down to its promenading and picnicking again. The race is the great event of the day, certainly, but there are old friends to be met, reminiscences to be exchanged, and luncheons and afternoon teas to be consumed. East meets West on Cup Day, and North meets South. It is much more than a mere race meeting to a sparsely populated country such as Australia. 
The conduct of horse-racing in Australia is marked by the regard paid to the convenience and comfort of the race-going public. Of the minor improvements introduced upon Australian race-courses, such as the numbering of saddlecloths, so that spectators can, by a glance at their cards, tell the name of a horse without reference to the colours worn by his rider, much has beell written. Betting in many of the Australian States takes place on the course through the agency of the totalisator, or pari-mutuel, while in other states, book-makers are controlled by the racing clubs governing the sport. Admission fees to the race-courses are strictly reasonable, and it is certain that while more of the Australians have a personal knowledge of racing gained from attending the courses, there is much less of the blind and ignorant gambling which takes place in the cities of Great Britain among men who never saw a race-horse extended. On the other hand, it would be idle to contend for one moment that the sport is as pure in itself in Australia as in Great Britain. Many of the Australian owners of race-horses are frankly concerned in racing for the sake of the money they hope to make at it, and incidents take place at some of the minor meetings that would not for one moment be tolerated by the English Jockey Club.

The climate of Australia largely accounts for the skill in cricket which has now become recog- 
nised as an Australian attribute. It would easily be possible in many parts of Australia to play cricket throughout the winter, and many cricketers devote that season to baseball, recognised as a summer pastime in America. Perhaps nothing is more eloquent of the Australian interest in sport, than the appearance of the newspaper offices during the progress of an Anglo-Australian cricket match. Hoardings are erected on the street frontage of each office, and from time to time, bulletins are posted there announcing the latest scores, with full particulars. All day long a crowd stands before each hoarding, disclosing by shrewd comments an intimate knowledge of the game. The same knowledge is often displayed by the much abused "barracker," who yells advice and reproach at the players during the course of the match. It is an evil custom certainly, and cannot be excused even in experts who may usually be found, not as spectators, but as active exponents of the game.

It is in this particular that an Australian cricket crowd differs most essentially from a similar gathering in England. The regular spectator can hardly be said to exist, for these large crowds are reserved for very special occasions. An ordinary club cricket match does not attract more than a few score of watchers, while every vacant piece of land proves that the Australian, as a rule, would rather play cricket than look at it. Football, 
on the other hand, draws its regular crowds of spectators; and it is not uninteresting to note that in most of the Australian States, the game is played according to a set of rules of local origin. The result is a fast, exciting game, best played on a dry field with a lively ball. For a bracing, sunny winter afternoon, there is no finer game for player or spectator, and the popularity of football can readily be understood.

A visit to one of the large city parks on Saturday afternoon will show that the Australian's aptitude for sport has caused him to adopt, not only all the recognised pastimes of Great Britain, but those of many other countries as well. $\mathrm{He}$ takes baseball from the United States, lacrosse from Canada, and polo from Asia, and can boast, in addition, of one or two sports that are peculiarly his own.

Most of these belong to the men of the bush, and, perhaps, the most interesting and characteristic among them is the sport of wood-chopping. A championship contest is at once a novel and exciting spectacle, and one not readily forgotten. Each axeman has his trainer, who plays the part of mentor during the contest, sometimes pointing to the spot where the next blow could be delivered with most advantage, and continually reporting the progress made by the other competitors. The logs to be severed-all practically of the same girth-stand upright, so that the axemen deliver their blows in the same position 


\section{The Australian at Play}

as when felling a tree. At a given signal, all fall to work, the sharp axes bite their way through the solid logs, and great segments of wood fall thick and fast upon the ground. It is impossible to predict where victory will rest, for those who start best often tire most rapidly, and sometimes a man will fall down from sheer exhaustion before the $\log$ is severed, since woodchopping mades a severe demand upon even the strongest frame. But the cheer that goes up when the first log topples over relieves the tension, and the victor's name and the time occupied in the performance of the feat are quickly announced. Cash prizes of a very substantial size are often won by expert axemen, a few of whom have exalted the accomplishment into a profession. Wood-chopping contests are advertised for many weeks beforehand, and during an afternoon devoted to this pastime, the sport is varied by contests in splitting and sawing wood.

Like the British soldier, the Western Australian miner is no stranger to the delight afforded by a camel race, with native riders. Many of the Afghans are very proud of the speed and endurance of their saddle camels, and it is no difficult matter to arrange a race, when the bulk of the fun is afforded by the efforts of the riders to urge the beasts along. The excitement is mainly confined to the Afghan spectators, who are all violent partisans, and shout frantically at the animals they do not wish to win, in the hope of 


\section{rgo Australian Life}

inducing them to lie down. The sequel is invariably a terrific squabble, during which challenges are thrown out and a fresh race is arranged. Even quainter than a camel race is the goat-race, peculiar, so far as I know, to the race-courses of Northern Queensland, and not unusually the brightest item in the day's programme of sport. In dealing with the amusements of the bush, it would be possible to dilate upon the sheepshearing contests that take place at the country shows, and the competitions in riding buck-jumping horses; also the rock-drilling matches that may be witnessed in a mining-camp. They are at least interesting as showing how the Australian makes a sport of the occupation in which he excels.

For shooting and fishing in Australia, no licenses are required, but the sportsman must have a knowledge of the close seasons, and of the birds and animals protected throughout the year.

Game is not everywhere plentiful, but the pursuit of it affords a pleasant excuse for the best of all Australian amusements, that of camping out. To pitch a tent on the banks of a clear stream, with plenty of good water-holes for bathing, and to sleep on a thick couch of springy fern is a joy in itself during the golden Australian summer. The stream holds all sorts of wonders, crayfish, and black fish, and little silver trout. A glimpse of a platypus may sometimes be caught, if the locality is a sufficiently remote one, and a sight 


\section{The Australian at Play}

of a pair of these water-moles at play is reward enough to the nature-lover for much patient watching. In the big water-hole, there will surely be black duck and teal, both very welcome additions to the larder, while the presence of the rabbit may be taken as a matter of course. Every patch of scrub may shelter a wallaby, but one may only look from a distance at the big forester kangaroos, hopping away at long range among the open forest trees.

Flour and bacon, with potatoes and onions, and, of course, tea and sugar, are necessities to the camper-out; also a pair of blankets, the oldest clothes available, not forgetting a pair of thick leather leggings as a precaution against snake bite, and just as much or as little sporting paraphernalia as may seem desirable. A horse and cart for the conveyance of these things, and of the tent, may be hired at the railway-station nearest the chosen spot, and then all arrangements are made. From the first dip in the water-hole before the sun is up to the last pipe smoked around the camp fire before turning in, the whole day is one round of keen delight. Damper and billy tea provide a meal that appears in the light of a choice confection, and the feeblest joke gains a zest from its surroundings.

Let me recall but one incident from among many memories of camp life. We had been in camp a week in a secluded valley in the Dividing Ranges, and during that time had seen no human 
faces but those of our own party. That night we were sitting around the fire under the stars, and finishing the last of a demijohn of excellent Australian wine bought at a vineyard on the road, when we heard, far away, the footbeats of an approaching horse. We listened in silence as they came nearer, and presently a horseman rode into our circle of firelight and drew rein. $\mathrm{He}$ stayed only long enough to explain his errand, for he was riding across country to the nearest township for a doctor. Then he drank the proffered cup of wine, and was gone into the darkness, the only man we saw during our stay there.

Even big-game shooting is possible for the ambitious sportsman in Australia. The Northern Territory has its herds of swamp buffalo, the descendants of animals introduced from the Malay archipelago in the middle of the last century. The shooting of these animals has been made an occupation by a band of adventurous men, who obtain handsome incomes from the sale of hides, horns, and salted buffalo beef. On Melville Island, near Arnheim Peninsula, the buffalo herds are estimated to number fifty thousand, the right of shooting them belonging to one man, who has rigorously preserved them for some years. The buffalo shooter must be able to ride well, and willing at any time to take the risk of an encounter with an infuriated buffalo bull. The country inhabited by the buffalo herds is 
swampy, and in holding ground, the buffalo, by reason of his large flat feet, holds a distinct advantage over a horse. It is the custom of the riders to keep a respectful distance while pursuing their quarry through the swamps, but to ride up to the animal's quarters when sound going has been reached. Then a shot from a carbine or shortened rifle shatters the animal's spinal column, and it is left to be despatched and skinned by the aboriginal assistants who follow in the horses's tracks, while the shooter himself rides on after the flying herd.

The sportsmen who have introduced animals and fish from the Old World are not altogether to be congratulated upon the result of their enterprise. The streams have been stocked with trout, which have thriven and eaten up the native fish, and multiplied, only to treat with contempt every lure in the shape of an artificial fly, and to fall an ignominious prey to the boy who baits with a local grasshopper. Foxes have been introduced and have betaken themselves to the hilly ground, where it is impossible to hunt them. They have become a pest to the farmer, and every Australian shoots a fox on sight as readily as he would a snake. The depredations of the rabbit in Australia are well known, and in some districts, hares are almost as great a nuisance. The house-sparrow and the Indian mina were surely unnecessary, even to the sportsman, but they are there, and it is impossible to get rid of them 
It is not surprising, therefore, that a gentleman who proposed introducing the African eland into Australia was begged by the Press to consider first whether that animal might not develop in his new habitat some latent vice not readily discernible in his natural surroundings.

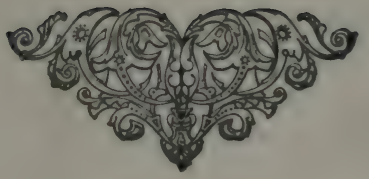




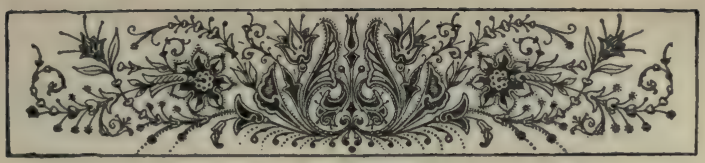

\section{CHAPTER XVI}

\section{THE ABORIGINES}

THE rapid dwindling of the aboriginal races of Australia, since the coming of the white man, is one of the least attractive incidents in the development of the continent. The Tasmanian blacks are already extinct, and of the scattered tribes of Victoria, only a few hundred members now remain. There were more than six thousand full-blooded blacks in New South Wales in 1882 , and twenty years later, the number had shrunk to less than three thousand. Mr. Archibald Meston, Protector of Aborigines in Southern Queensland, estimates that the number of blacks in that state was two hundred thousand in the year 1840 , and these, according to the same authority, had been reduced to twenty-five thousand at the end of the century. In spite of the most stringent laws passed for the protection of this remnant, they annually decrease by at least five hundred, and it is therefore the opinion of the authority I have quoted that the race will be practically extinct in Queensland by the middle of the present century. In Central and 
North-Western Australia, there are large tribes of blacks still living in their primitive condition of wildness, but the laws existing for their protection are not so carefully drawn as in Queensland. The opportunities for obtaining drink and opium are too many, and too frequent, and these tribes are also diminishing in number.

This rapid decay of an interesting race, unfortunate as it is, would appear to be inevitable. The unvarying testimony of all the authorities upon the subject goes to prove that contact with civilisation is fatal to the Australian black. His rapid extermination may have been hastened in the past by carelessness and cruelty of treatment that was grossly selfish on the part of the white man, but even the most intelligent and bestintentioned efforts to civilise this people have proved abortive and injurious to them. The only elements of civilised existence they seem able to assimilate are those calculated to prove destructive to them. "In their wild state, they get along all right," wrote one of their official protectors, "but when they are educated, what can we do with them?"

It is, indeed, only of late years that any organised attempt has been made to obtain accurate and scientific knowledge of their real and natural life, and of the curious and interesting tribal customs which survive among them. The task has been one of considerable difficulty, since the sources of information most readily 


\section{The Aborigines}

available have been tainted by communication and intercourse with the white man. It has, nevertheless, been possible to gather from the scattered remnants of the original Australian race, still living in a wild state, an excellent idea of life in Australia when the black-fellow roamed in undisputed possession of the continent. Of agriculture, he had not even the most primitive idea, and relied for food upon the wild fruits and vegetables of Australia, and upon the game secured during his fishing and hunting expeditions. The only animal he has ever succeeded in domesticating is the dog, and every tribe of blacks is still accompanied by large packs of these animals. As a rule, the black-fellow is fond of his dogs, and feeds them when he is able. But even when they have to look after themselves, they are certainly not treated with any active cruelty, nor set to fight for the amusement of their masters. The dogs are useful only to the wild black-fellows, who have to exist by hunting for the greater part of the year.

The same necessity which made him tame the dog has also impelled him to invent the most scientific wooden weapons that the world can show. It is curious that, although the development of the aborigine was arrested at the stage of the manufacture of wooden weapons, he has nevertheless succeeded in making the boomerang and the woomera, both highly ingenious and effective weapons, which he handles with a 
remarkable degree of skill. The boomerang has often been described, and examples of the woomera, or throwing stick, may be seen in most museums. It is a short, stout stick, notched at one end to receive the butt of an exceedingly long and light spear. With a woomera, the adept can throw these light spears with amazing force and accuracy, and although the spear-tips are made of hard wood only, these missiles served to kill kangaroos and emus, and afterwards sheep and cattle.

In a very interesting paper on aboriginal foods, Dr. Roth, of North Queensland, has enumerated more than two hundred varieties of fruits and vegetables which are eaten. When he can get them, the black shows no aversion to insects and reptiles of all kinds. Snakes are regarded as a delicacy, and the hills of some species of ants are plundered, eggs, larvæ, and mature insects being kneaded into a kind of paste, and eaten with relish. Grubs of all kinds, and especially the large, white grubs found under the bark of the wattle tree, are looked upon with extreme favour, and are sometimes roasted, and sometimes eaten raw. Earth-eating is also practised by some of the Queensland blacks, to satisfy a craving created by a disease common among them, and not unknown among the whites of the same locality.

In fishing and hunting, the black-fellow is at his best, and shows himself possessed of great 


\section{The Aborigines}

skill, cunning, and endurance. Emms are driven into traps and pits, or else speared, after much patient stalking. Snares are set for smaller birds, which are also killed with the boomerang. Swans and ducks are taken by swimming and diving, the head of the hunter being concealed in a mass of aquatic weeds. Kangaroos are tracked and speared, or run down with dogs, while the dogs also assist in driving the wallabies into snares and nets. The black-fellow catches opossums by climbing the trees in which they live, sounding the trunks for hollows in which these animals shelter.

Fishing is carried on in several ways. In angling, they employ the sucker-fish as a natural hook, but a more favoured method of taking fish is that of stupefying them by treading the water until it becomes very muddy, or by the use of some vegetable poison. They also make nets into which the fish are driven, and some tribes show great skill in spearing fish.

The manufactures of the black-fellow are not limited to the fashioning of his weapons, for the women make many articles of string. Some of this string is twisted from the hair of human beings, and animals, but the greater part of it is made of the vegetable fibre of the spinifex grass. This is chewed and soaked to get rid of the adhesive matter, and then twisted into strands in a very businesslike fashion. From the string thus made, nets for fishing and bunting are 
manufactured, as are the dilly-bags in which the gins carry their possessions. The unfailing amusement of the women and children, it is interesting to learn, is an elaborate imitation of the game of cat's cradle; for with a length of string, all sorts of designs are produced, each of which is supposed to bear resemblance to some natural object.

The amusements of the men consist in athletic contests, in duels, partly sham, but still of a very realistic nature, and in tribal dancing. Owing to the investigations of Messrs. Spencer and Gillen, the true significance of some of these dances or corroborees is now understood. The information was gathered in the course of two expeditions to Central Australia, when photographs and even cinematographic records of the corroborees were obtained. One typical dance is reserved for the rainy season, and is supposed to be conducive to the fall of the much-desired showers. In this dance, some of the actors represent ducks and other aquatic birds which make their appearance during the rainy season, and they deck themselves for the performance with objects symbolical of clouds and running water, thus preserving the significance attached to this special dance.

At least one aboriginal dialect has been reduced to a written language by Dr. Roth, assisted by two German missionaries, Messrs. Schwartz and Poland, of the Lake Bedford 


\section{The Aborigines}

Station. This language is exceedingly interesting, on account of its remarkable inflections and grammatical complications, an extremely limited vocabulary of root words being most ingeniously employed to serve all the purposes of a spoken language. Dr. Roth declares it to be identical with the dialect of which Captain Cook made a vocabulary in the year 1770 , since which time the spoken language appears to have undergone few, if any, alterations.

Interesting as the black-fellow undoubtedly is while he remains in his wild condition, when he comes into close contact with the white man he presents a spectacle that is pitiable and pathetic. A visit to one of the aboriginal reservations will convince any inquirer that, with the very best intentions, the Australian Governments are able to do but little for those people. Houses built to shelter them are kept in a bare and sordid state, and the uncultivated state of the good lands they possess shows that it is impossible to instil into them even the rudiments of agriculture. The large proportion of half-caste children, while it is a reproach to the whites, is also eloquent of the absence of any vestige of morality in either black man or woman. Neither the stringency of laws, nor the vigilance of paid officials serves to protect the black race from itself; for it dates back to an era before the stone age, and cannot be in any way reconciled with the conditions of to-day.

The skill of the aboriginal as a tracker has 
formed the subject of countless stories, many of which can be readily verified. Attached to the police force of each of the Australian States is a band of these black trackers, whose services are most useful in tracing the footsteps of criminals or of unfortunates lost in the bush.

These trackers are drawn from the wildest and least civilised tribes of Northern Australia, and it is curious to notice how rapidly they lose the instinct which makes their services of value. After a very few years, it is generally found necessary to dismiss them and to fill their places with men freshly drawn from the wild existence natural and necessary to the welfare of the Australian blacks. In a book on the Black Police of Queensland, Mr. E. B. Kennedy, who had a long and varied experience with that force, narrates many instances of the tracking ability of the black-fellow. One of these is of especial significance, because it proves that the tracker loses none of his skill when transferred to another land where the local conditions are unfamiliar to him.

Attached to one of the Australian contingents sent to the Boer war was a native Australian tracker called Billy. Some English officers, when discussing scouting and kindred topics with their Australian colleagues, expressed their doubt as to the powers of the tracker being as great as they were represented, although admitting their belief that the stories told them might have some 


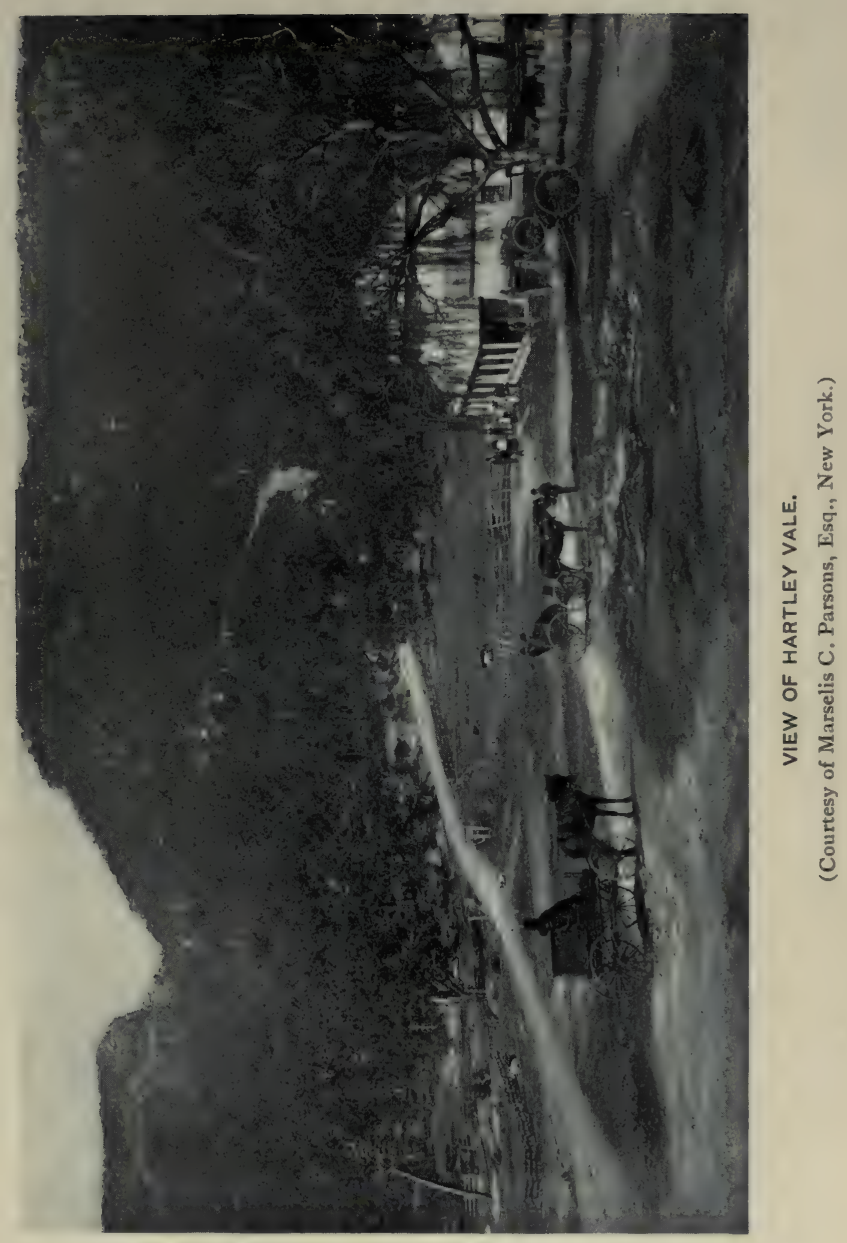





\section{The Aborigines}

foundation in fact. A trial was at once arranged, and five officers set off, at different hours and in different directions, two on foot, and three on horseback; Billy being meantime locked up. When released he followed up each track in turn, and on his return to camp, note-books were taken out and he was told to proceed. Billy forthwith sketched the routes taken by each, described how one had tied up his horse, and climbed a tree, although there was neither "possum or sugar bag" in it. One of the footmen was a "silly pfeller," for he had gone out in his socks and cut his foot, and so lamed himself for the rest of his journey. The half-burnt match of another man who had lighted his pipe was produced, as well as hairs establishing the fact that the three horses were dark brown, light brown, and grey in colour. In short, Billy quite convinced those English officers that his powers were as great as had been claimed.

Apart from this sphere of usefulness, the aborigines make splendid stockmen, for they are good natural horsemen, and their keen sight and hearing, as well as their instinct for observation, are of the greatest advantage in this work. It more closely resembles their natural life, providing them with plenty of change and excitement, and with the nomad existence to which they have always been accustomed. But should the tribe to which they belong make its appearance in the neighbourhood, they at once grow unsettled and 
sullen, and nothing will restrain them from "going wild," for a time at least. As they grow older, this longing for freedom from restraint gains upon them, and they become less diligent and attentive to their duties. The best work is obtained from those who are taken when quite young, and removed to some distance from the district to which they belong.

The women are more reliable, and on the stations in the far West and North, perform all the household drudgery. Some of them make very faithful and useful servants, and as they are very fond of children, are frequently employed as nurses. They are cheerful and good-tempered, fond of a joke, and of bright colours, and easily managed by any one who understands them. Ladies who have grown accustomed to them will often declare that they prefer them to the best white servants, especially for work in the bush. This opinion is shared by some of the gins themselves, if the story told by a Western station holder be true. His wife employed an Irish servant-girl as well as a black gin, and between the pair an endless quarrel went on. For the Irish girl, the lady of the house made a dress, and promised the gin one exactly like it. She was rather surprised to hear the latter begging for something of different pattern, and on asking the reason was told, "Mine think it people take me for sister that white Mary."

According to bush report, the black-fellow has 


\section{The Aborigines}

a very poor head for figures, and is unable to count beyond ten. Hence the story of the blackfellow whose master took him to Sydney, and who, on his return to the station, was questioned by the boundary-rider, "Well, Jacky, did you see many people in Sydney?"

"My word! Tousands! Millions! Very nearly fifty !"

Even on the far-out cattle stations, poor Jacky is worse off than in his wild state. For his rugs of native animals, he learns to substitute absorbent blankets, and the damp affects him in a terrible way. Pulmonary complaints develop with an awful rapidity, and the black-fellow is unable to make any fight against them. $\mathrm{He}$ is even worse off in the more settled districts, where he may be seen hanging around the publichouses and begging for money and tobacco.

Some of them find employment on the sugar plantations, but in too many cases their employers are Chinamen, who bribe them to work with gifts of opium. There is a law forbidding any one to supply this drug to the aborigines under very severe penalties; but the Chinese defy it, and add to the offence by supplying the opium in a most deadly form, adulterated with the ashes from opium pipes already smoked. Indulgence in this poisonous drug is even more fatal to the blacks than spirits, but they readily acquire the craving for it, and will do anything for a small quantity. 
The myall, or wild black-fellow, is frequently a law-breaker, his peculiar weakness being the spearing of cattle. At a place called Wyndham in the north of Western Australia, there is a gaol devoted solely to aboriginal prisoners, the majority of whom have been convicted of this offence. This gaol will accommodate a hundred prisoners, and is usually full, the ordinary sentence imposed for cattle-spearing being from three to six months. It would be interesting to know to what extent the wild black is acquainted with the rights of property, and exactly what difference he sees between spearing a bullock and spearing a kangaroo.

It seems idle to express any hope for the future of this race, or to propose any plan for arresting its rapid decay. The portions of Australia not yet occupied by the white race are considered to be the most arid and unproductive areas of the continent, and these are all that is left to the myall of the country he once held without dispute. Educational influences have been expended upon them to worse than no purpose, for it is generally conceded that the black children brought up in the mission schools have turned out more thievish, idle, and vicious than any of their fellows. The utmost distinction ever attained by any member of the race has been to become a clever jockey, a swift runner, or a skilful cricketer. Regeneration of this people seems out of the question, and the most that can 


\section{The Aborigines}

be done is to treat it with the kindness that is extended to a dying man. On this point, the laws of some of the Australian States might well be revised, and steps taken for their stricter enforcement.

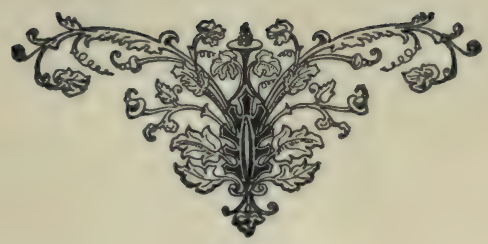




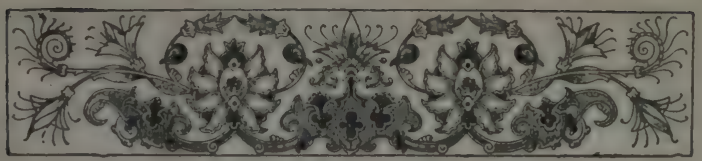

\section{CHAPTER XVII}

\section{A WHITE AUSTRALIA}

$A \begin{aligned} & \mathrm{LTHOUGH} \text { untroubled by any questions } \\ & \text { arising out of the presence of an indigenous }\end{aligned}$ coloured race, the Australians recognise a more serious danger in the proximity of Asia and its surplus millions of population. They consequently enforce the most stringent measures of exclusion against the coloured alien, and especially against Chinese, Japanese, and Indian coolies. It is contended, and with some force, that the development of Northern Australia is seriously retarded by these restrictions, and there are those who say that tropical Australia will always remain a wilderness if white labour is relied upon for its cultivation. The same arguments are advanced in support of the employment of Kanakas, or South Sea Islanders, upon the sugar plantations of Queensland. Before the restrictive measures were applied, a large number of coloured immigrants had already found their way to Australia, the latest census revealing their number at fifty-five thousand, of whom thirty-two thousand are Chinese, and ten thou- 
sand South Sea Islanders, the bulk of the remainder consisting of Hindoos, Japanese, Manila men, and Afghans.

The reasons that induced the Commonwealth Parliament to decide that no addition should be made to these numbers have frequently been rehearsed. The exclusionists point to the difficulty thrust upon the United States by the presence of a large negro population. The low standard of living adopted by the coloured races, the undesirable intermixtures of race already evident in some parts of Queensland, and the absence of due regard for morality and sanitation, are further arguments advanced by the advocates of a "White Australia." Even those who admit that coolie labour is best suited to tropical Australia shake their heads over the impossibility of confining the coloured alien to the North, and so arrive at the conclusion that it is better the North should suffer than that all Australia should be overrun. It is not proposed to enter into the discussion of this question, but rather to describe some of the very interesting occupations in which the coloured alien is already engaged.

It should first be understood that the exclusionist legislation of the first Commonwealth Parliament deals with two aspects of the coloured labour question. One Act, dealing with the indentured labour of South Sea Islanders, sets a term to the employment of this labour. The last boats carrying indentured labourers from the 
islands to Australia arrived in Queensland early in 1904, and from that time, the Kanakas were deported as their indentures expired. This Act was supplemented by an offer of bonuses to the canegrowers employing white labour on their plantations, the amounts of the bonus being proportionate to the quantity of sugar produced. The object of these bonuses is the gradual substitution of white labour for coloured, so that the deportation of the Kanakas may be accomplished without dislocating the industry. The result of this experiment will be watched with the keenest interest, especially by those who contend that the white man is physically incapable of the work required on a tropical plantation. The second legislative measure provides, among other things, an educational test whereby undesirable immigrants may be excluded. The greatest merit of this test lies in its elasticity. The test may be reduced almost to vanishing point for the benefit of immigrants whose presence is welcome, while an undesirable can be confronted, if necessary, with a stiff paper in Greek. The Commonwealth Parliament has carried its opposition to coloured labour to the length of abolishing it on the boats carrying the mails to and from the United Kingdom, and there can be little doubt that this attitude represents the sentiment of a majority among Australians.

The reader has already been introduced to the Chinaman at his cabinet and laundry works in 


\section{A White Australia}

the cities, and raking over the abandoned workings of the gold-fields. He is equally successful as a market gardener, and may be found pursuing that occupation on the outskirts of almost every Australian town, whether large or small. His ramshackle wooden hut is unmistakable, the roof patched with strips of rusty tin, and the broken windows obscured by sheets of dingy paper. In this hovel, half a dozen or more coolies are crowded together in a condition that would appear to any European as distinctly uncomfortable and unsanitary. A set of bunks, one above the other, lines the walls, and a peep into the malodorous kitchen proves that John Chinaman's fare is as meagre as his sleeping accommodation. In the tumble-down stable, however, may be found a sleek, well-cared for horse, luxuriating in comfort. "Fat as a Chinaman's horse," and "fat as a larrikin's dog," are two similes of a significant frequency in Australia. The garden itself is a picture of neatness and good management. The little square raised beds of cabbage and onions are free from weeds and flourishing, a result achieved by constant diligence and a system of liquid manuring it would not be advisable to investigate too closely, if the vegetables are to be eaten. John is not always cleanly, just as he is not always communicative. On some points, he is bubbling over with information; on others, his attitude is that of the poor untutored foreigner with a very imperfect knowledge of the English 
language. He shakes his head and smiles blandly, murmuring the words, "No savvy," at intervals. For all his politeness, it is not possible to break through his wall of reserve.

In Northeru Queensland, the Chinaman is often a wealthy shopkeeper, and an employer of both coloured and white labour. His admirers can point to his donations to the charities in proof that he is not ungenerous, and to his unfailing politeness to show that he is a genial soul, shamefully misunderstood. The fact remains that his object in life is to return to China with as much money as he can possibly carry with him, and that meantime his low standard of morality is the more dangerous to his adopted country because he seldom brings his womenkind with him. The Chinaman has done good work in the Northern Territory by proving the immense possibilities of that district for raising coffee, arrowroot, cotton, and other tropical products. Against this service must be set his utter want of scruple in the employment of the aborigines, whom he rewards with doles of rum and the opium that has so deadly an effect upon them.

Against the Chinaman as a citizen may further be urged his taste for secret societies, and organised opposition to the law. Definite information on the subject of his secret societies may not readily be obtained, because of the reserve he maintains upon this subject above all others. It is known, however, that there are two important 


\section{A White Australia}

societies with branches in every Chinese community in Australia, and that one of these is a wing of the Boxer organisation so prominent of recent years. Evidence of the existence of Chinese organisations for bribing policemen and magistrates has more than once been obtained, although it is possible that John may be credited with greater subtlety in this direction than he really possesses.

An example of the slimness of the Chinaman is afforded by the following letter, written in reply to a demand for rent from his landlord, by a Chinaman, who, I have been assured, is a shrewd and clever business man, with a capital knowledge of colloquial English, both written and spoken:

\section{"DEAR SIR:}

"To support our public doctrine of the prestige illustration to restore salubrious enjoyments prime to celebrate the Cup season. I acknowledge your transit, will supervise the same your prime of health, I appreciate you. As to the detouration of the season it will prophesize to foretell the thirstiness of the consecuting months: occasion with heavy rainfall. Household dwellers, with inferior roof, will soon complaint and suffer same. Strange to say the Being's spending most of the hour in dwelling-houses is the bedroom: but due to inferiority of the roof and walls, sufferers (sleepers) are compel to retire from their 
natural slumber. At the same time foundation of houses are generally destroyed through neglect of improvements. However, this matter refer to the same idea of our dwelling place. The best time to inspect and improve is during the rainy season. In conclusion with best wishes and sustain, confirm interest to aid the sufferers.

"Yours truly,

"Wing Mow."

As no cheque accompanied this lucid note, the landlord took legal proceedings, and found that his agreement had been signed by a Chinaman who was not of age, and therefore not legally responsible. This is only one of many examples that could be adduced in illustration of the cunning employed by the Chinaman in playing "the game he does not understand."

At Thursday Island, in Torres Straits, and at Broome, on Roebuck Bay in the north of Western Australia, are situated the headquarters of the pearling industry. Most of the Japanese, Malays, and Manila men in Australia are engaged in this occupation, and from each centre a fleet of some three hundred pearling vessels put out. The crews and divers engaged on these boats are all coloured men, who work under the commands of a white skipper. The chief product of the industry is the pearl-shell, for the pearls themselves, although giving a romantic and speculative interest to this occupation, are regarded as only a secondary consideration. Most of the boats are 
fitted with an air-pump and diving apparatus, although Thursday Island still sends boats to the shallower fishing-grounds manned with swimming divers only. The maximum depth at which the man in diving dress can work is twenty fathoms, or one hundred and twenty feet, and, at that depth, the pressure of water is so great as to produce very unpleasant effects upon those who are called upon to endure it. At one time, white divers were not unfrequent upon the pearling grounds, but so many of them became afflicted with paralysis that diving as an occupation has been abandoned to the coloured man. The white master may occasionally descend in the diving dress for the purpose of examining the fishinggrounds for himself, but that is all.

When the diver is at work, the boat is allowed to drift, and he walks along the ocean-bed beneath it. The shell he gathers is sent in a bag to the surface, where the master opens it and searches for the pearls. This is the speculative side of the business, which appeals most keenly to the adventurous class engaged in it. Fortune is proverbially fickle, and men who have spent many years at the fisheries without finding a pearl of great value have to accept with resignation the fact that the most precious gem ever found in Australia, sold in London for $£ 5000$, fell to a novice who had just embarked in the pearling trade. On those northern coasts of Australia, the difference between the tides is very great, and 
the residents often find a few oyster shells upon the beach at low tide. A new arrival there had the pleasure of opening his first find and discovering two pearls, one worth $£ \mathrm{IO}$, and the other worth $£ 50$. This took place in the presence of a resident who had been picking up shells for years without any notable result, and the disgust of the latter was naturally too deep for words. The pearls are sometimes found in the fish, sometimes attached to the shell, and sometimes in a "blister" covered over with mother-of-pearl.

The crews of the pearling boats are paid from thirty to fifty shillings a month, according to their length of service, while the divers earn a great deal more. Most of them are engaged under contract at Singapore, and when the term of service has expired are able to renew their engagement on better terms. A clever and reliable diver is thus placed in the position of being able to make his own terms, and these are frequently a very remunerative kind. The masters of the boats are made responsible for their men, and should one of these desert his boat and escape into Australia, a penalty of $€ \mathrm{r} 00$ is inflicted. As a further precaution, these men are not even allowed to go ashore until an official permit has been obtained. These conditions are considered quite severe enough by those engaged in the industry, and they threaten they will transfer their headquarters to Dutch territory (in Java or elsewhere) if any further restrictions are imposed. 


\section{A White Australia}

The business is undoubtedly a remunerative one. A clever diver will collect five tons of shells in the course of a year, and the best quality of shell is worth $£ 200$ a ton. As already stated, the value of the pearls is a secondary consideration, but although it varies very greatly it is always well worth taking into account. The initial outlay on the purchase, equipment, and provisioning of a boat may be set down at from $£ 500$ to $£ 1000$, and the extent of the fishing-grounds is so great that, up to the present, there has been little talk of overcrowding.

Outside the pearling industry, the Japanese, with his womenkind, is no stranger to Australia, and the degraded lives of these visitors afford sufficient reason for the stern embargo now placed upon them by the authorities.

The climate and soil of the eastern slopes of tropical Queensland are well suited to the cultivation of the sugar-cane, and the industry has obtained so firm a footing there that the most active controversy is still maintained concerning the probable effect of the exclusion of Kanaka labour. The islanders, both men and women, have in the past been introduced from all parts of the South Seas, and have proved themselves well fitted for the work in the cane-fields. The methods employed to induce these people to leave their island homes were carefully regulated by the Government, each boat employed in the recruiting work being forced to carry a Govern- 
ment agent. The remuneration offered to the labourers, though slight compared to the wages required by white men to do the same work, was nevertheless sufficient inducement to those who engaged themselves, and in proof of the statement that they were usually well treated may be advanced the willingness shown by many of them to engage for a second period. Those who returned to their island homes usually laid out their earnings in brightly coloured clothes and valueless fancy goods, but after a few weeks of island life, they were frequently very glad to return to the plantations again.

The work of cultivating the sugar-cane, from the propagation of the young plants to the cutting of the ripe cane for transport to the mills, necessitates hard physical labour in a sweltering climate. The man who would "trash" the cane must stand hidden in a breathless cane-brake, while he tears the dead and dying leaves from the lower parts of the stalks. The oppressive atmosphere is laden with minute particles of vegetable fibre that choke the throat and penetrate the lungs. This task, and the still heavier work of cane-cutting, the Kanaka undertakes cheerfully. The women also work in the fields, hoeing the ground and freeing it from the rank crop of weeds that spring up so rapidly in the moist heat. These people live in great wooden barracks, and their staple foods are maize porridge, molasses, and salt beef. Most of them are Christians, and 
the visitor to a sugar plantation will carry away a recollection of the fervour they exhibit in the singing of hymns of the Moody and Sankey order.

Among the objections taken to the measure providing for the deportation of the Kanakas was the possible danger to the civilised islander himself. It was contended that the labourers ran no inconsiderable risk of being killed and eaten by their savage island relatives. On this point, the most reassuring testimony was obtained from the missionaries working among the islands, than whom no one is more competent to express an opinion. Some of these gentlemen entertain the hope that the return of the Queensland labourers will have a good effect among the islands, and that some agricultural development will take place, resulting in the expansion of island prosperity. In any event, the Australian Government has charged itself with the responsibility of transferring the Kanaka labourers to islands where neither their lives nor their prosperity will be in any danger.

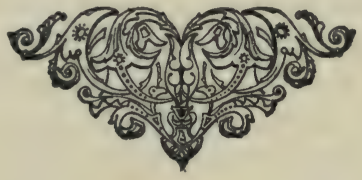




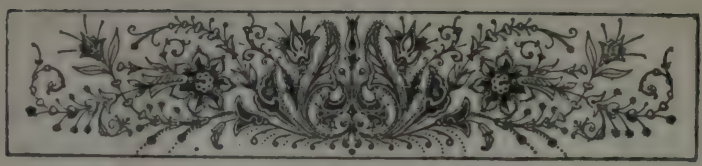

\section{CHAPTER XVIII}

EDUCATION, IITERATURE, AND ART

THE Australian States charge themselves with

the primary education of children, either without expense to the parents or for a fee that is purely nominal. There may be found a few private elementary schools, but it is estimated that quite eighty per cent. of Australian children attend the State schools. The difficulties in the way of supplying the more sparsely populated bush districts with schools and teachers can be readily imagined: and they are solved, in many cases, by expedients that can only be justified by urging that any sort of education is better than none at all. It is no uncommon thing to find a hardworked bush teacher in charge of two schools, and holding classes in each on alternate days of the week. Each school may be attended by from twenty to thirty pupils, their ages ranging from six to sixteen: and how the teacher contrives to maintain order and discipline is a question he alone can answer. Many of the bush children live far away from the lonely little schoolhouse, and have to walk or ride long dis- 


\section{Education, Literature, and Art $22 \mathrm{I}$}

tances in order to attend. Most of these children have duties to perform at home as well, both before setting out for school and on their return home again. Their education is not accomplished, therefore, without a very considerable strain being thrown upon both pupils and teachers, and for that reason, perhaps, it is the more highly valued. It is at least certain that residents in remote and sparsely-settled districts make every effort to obtain schools in their neighbourhood, and insist upon the regular attendance of their children, wherever possible.

The difficulty with regard to religious instruction is constantly occurring in connection with the free schools of Australia. It is a question complicated by the absence of a State Church in Australia, and by the fact that the balance between Roman Catholics, Episcopalians, and other Protestant sects is very even. In some States, the instruction is entirely secular, and the duty of providing religious instruction for the children is cast upon their parents. It may be said, however, that with the view of assisting in every way towards the religious instruction of the children, the State places the school buildings at the service of such religious instructors as may choose to use them, after school hours, for the purpose of religious instruction. The scholars who wish to attend may do so, but those who prefer to absent themselves are under no compulsion of any kind. In other States, religious instruction is included 
in the programme of education, the instruction consisting of the reading aloud of chosen passages from the Bible and works of a moral character. Of the two systems, the former has given the more general satisfaction, and in spite of warm remonstrances from some of the religious bodies, it seems unlikely that any alteration will be made in the free, compulsory, and secular educational system.

There is nothing exceptional about the course of education provided, unless it is the importance attached to physical drill. All children are drilled, but the elder boys are attached to the Australian military forces, by means of the cadet corps. Almost every large school has its band of cadets, who wear neat khaki uniforms and are armed with light rifles, in the use of which they are frequently instructed. Every year, these boys have shooting matches, and the scores prove that among the youngsters there are many who have already become skilled marksmen. On leaving school, the cadet can attach himself to a corps better suited to his altered mode of life, and from that body may pass into the Militia force without having suffered his military training to fall into neglect. When the Prince of Wales visited Australia for the opening of the Commonwealth Parliament, four thousand of these cadets took part in a review held at Melbourne. Foreign officers from most of the European armies witnessed the review, and much as they were struck 


\section{Education, Literature, and Art 223}

by the appearance of the citizen army of Australia, the cadets moved them to the greatest admiration. Owing to this practical system of military drill, there are few young men in Australia at present who do not know something of drill and the use of the rifle.

Secondary education is almost completely given up to private enterprise, and the result is far from being satisfactory. The exclusive aim of many Australian "private schools" is to pass as many scholars as possible at the matriculation examination of the State University. This examination has a commercial value, for many banks, insurance offices, and similar institutions make it a sine quâ non for entrance into their services. The proportion of matriculated students who afterwards attend University lectures is remarkably small, most of them entering commercial life as soon as they matriculate. The masters of the private schools have, therefore, but one end in view, and many and ingenious are the cramming systems devised in order to obtain good results at the matriculation. If the advertisements of the private schools may be accepted as a guide, success in this direction is the surest method of obtaining fresh pupils.

Most of the mining centres have schools of mines, subsidised by Government, where scientific and technical education may be obtained for very moderate fees. The instructors at these mining schools are, as a rule, very competent men, and 
the courses in such subjects as assaying and mining engineering are of sterling practical worth. To these schools Australia owes the very thorough and up-to-date methods of mining in practice on all the more important gold-fields. Indeed, education in Australia has a basis that is nothing if not practical and commercial. At the universities, this side is ever uppermost, the majority of the students attending lectures for the sole purpose of qualifying for professions. As far as the men students are concerned, this statement has almost a universal application: their object is to obtain the necessary degree as quickly as possible, and to begin at once the practice of some profession. Some of the women students who sit in the same lecture-rooms are probably less commercial in their pursuit of knowledge, and in them the professions find their ideal pupils, who follow learning for learning's sake alone. But if the Australian universities are hampered in their aspirations by the practical and utilitarian nature of the young community in which they exist, it must also be said that they make little or no effort to reach the classes who might be inspired by a genuine desire for higher education. They exercise as little influence as could be expected from conservative institutions in a democratic community, and have become strangely out of sympathy with Australian life and Australian ideals.

The Australian Press is an educational force 


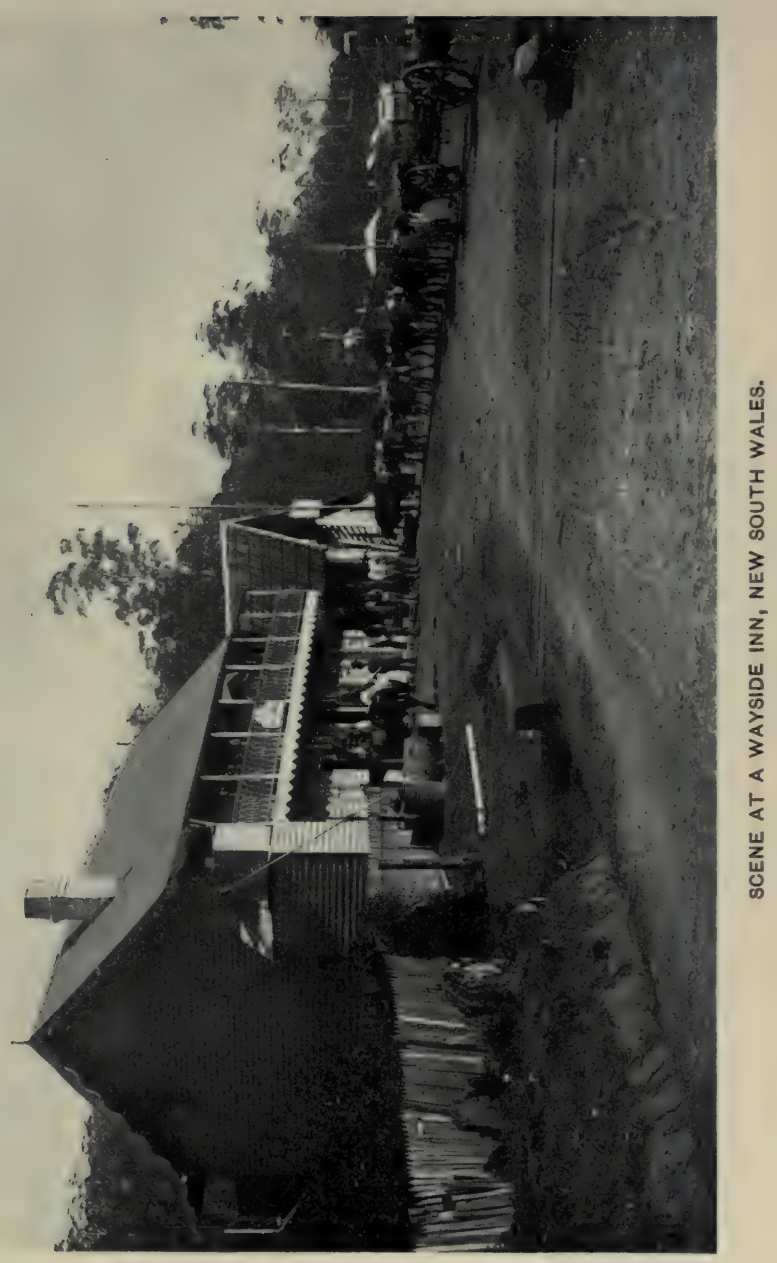





\section{Education, Literature, and Art 225}

more closely in sympathy with the people. It has been said that a people gets just as good newspapers as it deserves, and if that be true, the deserts of the Australian people must be high. It has to be remembered, however, that the dailies and weeklies of the Commonwealth are more than news sheets and political organs, since they partly fill the gap created by the absence of any representative Australian magazine or review. Each of the capital cities maintains two or more daily papers comparable to any similar productions in the world. To preserve the mean between accuracy, dignity, and decorum on one side, and dulness on the other is a task that is yearly becoming more difficult to the newspaper editor, but it can fairly be said that the Australian daily papers are neither dull nor unduly sensational. For the people of the bush, weekly editions are prepared, containing-in addition to a résumé of the week's news - much useful matter pertaining to agricultural and pastoral affairs, London letters, serial stories by the best writers, illustrations of the events of the week, and many other features. The arrival of these weekly budgets is an event upon the station or selection, and the interest they create furnishes an explanation of the fact that the average bushman is far from being a rustic, but is very often closer abreast of the times than the man in the street.

Eiven more characteristic of Australian life are the weekly satirical and society papers, and 
among these the Bulletin is by far the ablest and most influential. To describe the Bulletin merely as a satirical and society paper is to do it a very grave injustice. By no mere tricks of satire and news-gathering can any paper sway part of a nation; and this, by its deadly earnestness, great ability, and ferocious plain speech, the Bulletin has continued to do for many years. The most talented artists and the brightest writers of all Australia are in its service, and nowhere in the world is a political situation better expressed in a clever cartoon, or a newly proposed legislative measure more ably reduced, in a small space, to perfect lucidity and simplicity. It is not contended for one moment that the whole policy of the Bulletin commends itself to one half of its regular readers, for it frankly advocates the independence of Australia under a republican form of government. But the Australian who is content with things as they are, or even desires some closer connection with the Motherland, cannot afford to do without his Bulletin for this reason. For the paper is at once the most interesting chronicler of Australian matters, and the most trustworthy guide in Commonwealth affairs. Other papers have, unfortunately, strong provincial leaning, but the Bulletin steadfastly sets the national question before all others, and so commands the respect and admiration of the many nationalists among the young Australians.

The Bulletin renders a further service to Aus- 


\section{Education, Literature, and Art 227}

tralia in its sympathetic encouragement of Australian literature and art. "There is no Australian literature," wrote the editor of a serious London review to an Australian writer who offered him an article upon that subject. This is a hard saying, and of its truth or otherwise it would be useless to contend. It is certain that the path of literature, rough and painful as it is to the beginner in any land, bristles in Australia with obstacles that will disappear when the country is older.

Reference has been already made to the absence of any notable Australian magazine or review. Numbers of such publications have been launched, and none have failed for want of writers of ability, or subjects of importance or interest. Their failure has been a financial one, and due, in the first place, to the expense of printing and publication where wages are high, materials are dear, and the circle of appreciative readers is small. Such publications have had to compete with the magazines and reviews of England and America, produced under circumstances vastly more favourable to cheapness and advertising support. One after another they have dwindled and died. The Australian publishing firms have contended with the same adverse circumstances, heightened by the fact that the Australian market is flooded by cheap "colonial" editions of the newest books published in London. Thus for three and sixpence one may buy in Aus- 
tralia a copy of one of Kipling's volumes of poems, the cheapest edition of which costs six shillings in London. The Australian belief in protecting local industries has not yet reached the stage of a scheme to encourage the Australian author and publisher, and at the present time the author finds the easiest and most profitable method of publication in London. To this Mecca many Australians of promise have gone, in time to lose touch with Australia, and to devote themselves to subjects of closer interest to the wider public they address.

Had it not been for the Bulletin, the history of the last fifteen years would certainly have confirmed the dictum of the London editor. The pages of the Bulletin have always been open to writers of Australian verse or prose stories or sketches of moderate length.

Literary ability and the Australian interest are the two essentials for publication in the Bulletin, and verse and story alike have to be racy of the soil. The Bulletin writers have chosen for their theme the varied aspects of bush life-the life of the shearing-shed and the cattle camp, the racecourse, the mines, and the bush track. The works of the more popular of these writers have been collected and published in book form, and are now familiar in town and country alike. Henry Lawson, A. B. Paterson, Edward Dyson, Barcroft Boake, Victor Daley, Will Ogilvie, Roderick Quinn, and a number of others bear 


\section{Education, Literature, and Art 229}

names as well known in the bush as those of the standard English poets. Their influence in the main is invigorating, as any influence must be that tends to make the Australian more keenly alive to the interests and beauty of the land he lives in. This school of Australian literature succeeds an earlier group of writers whose names are more familiar to British readers. Chief among them were Adam Lindsay Gordon, Henry Kendall, Marcus Clarke, "Orion" Horne, and J. Brunton Stephens, all of whom are now dead.

The Australian theatre is almost an exact counterpart of the theatre in Great Britain. The buildings are designed on the same lines, with but little regard for the coolness and ventilation necessary in such a climate, and one may see, as in the English provinces, the latest London success, enacted by a company of London players. Save for a few melodramas, and dramatic versions of well-known Australian novels, such as Robbery Under Arms, or His Natural Life, the Australian drama does not yet exist. There are music-halls, but, robbed of their attractions in the shape of permission to smoke and consume alcoholic liquor on the premises, they do not enter into so keen a rivalry with the legitimate theatre as in other countries. The taste for light opera and musical comedy, so marked a development in the theatrical preference of Great Britain and America during recent years, is even more noticeable in Australia, where grand opera is also 
popular among the people. The universal love of music which makes this possible is also accountable for the frequency and the success of ballad concerts, and these, rather than the musichalls, are the rivals which the theatrical manager has to fear.

The Australian artist complains, with good reason, of the discouraging conditions in which he works. Large sums have been spent in the foundation of public art galleries, but a mere driblet of this money has been devoted to locally painted canvases. In connection with some of these galleries, a fund exists for providing young artists of promise with the means of study in Europe, and the expenditure of this money has almost an invariable result. Having once come into touch with the world's art centres, the artist does not find it easy to return to the practical and commercial world of Australia, so that, up to the present, these travelling scholarships have done more for Australian artists than for Australian art.

At present, London proves an irresistible magnet for Australians following the artistic professions, and it will be many years before this migration can be expected to cease. Even if the Australian community were less commercial and more artistic, London would still offer a wider sphere and more congenial surroundings, as well as larger rewards. It is not in Australia, then, but in London that the successful painters, 


\section{Education, Literature, and Art 23I}

singers, authors, and actors expect to crown their careers, and so long as this remains true, the growth of art that is distinctively Australian must necessarily be slow.

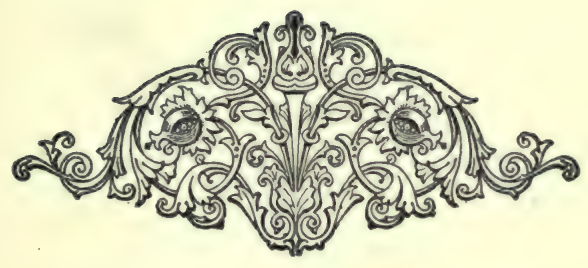




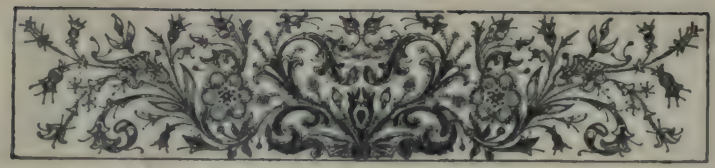

CHAPTER XIX

NATIONAL LIFE IN AUSTRALIA

THE average Briton has always been content to class Queenslanders and Tasmanians alike as Australians, and more loosely to include even a New Zealander in the same description, owing to a natural confusion of the words Australia and Australasia. He, therefore, finds extreme difficulty in grasping the distinctions that grew up in Australia with the granting of separate constitutions to the various states, and the consequent checks experienced by the statesmen who undertook the task of welding them into a Commonwealth. Even to indicate the whole of these distinctions would be a noteworthy task, but a significant feature of them was the tariff retaliation brought about by differences in fiscal policy. How far these differences injured the progress of Australia was conclusively shown in the first three years of the existence of the Commonwealth, by the expansion of inter-state trade following the removal of the customs barriers.

Instances of rivalry between neighbouring communities of the same race are not uncommon 


\section{National Life in Australia 233}

in the history of the world, but Australia has furnished a unique example of the length to which these unreasoning jealousies can be carried. Lest the products of one division of a State should find their natural outlet at the seaport of a neighbour, the construction of a long and expensive railway would be undertaken, and an annual loss incurred in its working and maintenance. Indeed, the railways of Australia remain as a standing illustration of the injurious results of this provincialism. The traveller from New South Wales to Victoria must leave his train on the border line, and enter another, because the railway lines of the two states have different gauges. Another break of gauge occurs at the boundary between Victoria and South Australia; and as a result of this failure in co-operation, a huge sum will have to be spent at some time in standardising the railway gauges. If a reason be sought for the neglect in conserving the waters of the river Murray for purposes of irrigation, it will be found in the fact that this river, the most important in all Australia, forms the boundary between two states, and finds its outlet in a third. Instances could be multiplied to show how state jealousies have retarded Australian progress.

In the days when this provincialism was at its worst, there nevertheless existed aspirations for a wider national life. Societies were formed with the object of fostering a national spirit, and one of these organisations exercises no small influence 
upon the everyday life of Australia at the present time. 'The Australian Natives' Association was founded at a time when British statesmen regarded the Colonies as a burden, and the word "colonial" was employed as conveying a meaning of inferiority. Even in Australia, where the proportion of British-born folk was then greater than at present, colonial wines, colonial boots, and colonial customs were openly despised.

To combat this tendency to undervalue Australian things, a number of young men, who were proud of their Australian birth, formed the Australian Natives' Association. Among them were Sir George Turner, Treasurer in the first Commonwealth Ministry, Mr. J. L. Purves, leader of the Melbourne Bar, and a number of others afterwards prominent in Australian political and professional life. The avowed object of the association was to make the native-born Australian proud of his country, and to encourage Australian manufactures, Australian art, Australian literature, and everything else Australian.

Each branch of the Association combines the functions of a benefit lodge with those of a debating society. Meetings are arranged at regular intervals, when the members first transact the business of the branch and then discuss some chosen subject, usually Australian in interest. Every member who shares the benefit system of the Association pays a weekly levy, amounting to a little more than a shilling. This assures 


\section{National Life in Australia 235}

him medical attendance and medicine when sickness comes into his house, a weekly allowance, should he himself be prevented from attending to his business by illness, and a provision for his fitting burial after death. This sick and funeral fund represents the business side of the Australian Natives' Association, and is really responsible for the continuance of its growth, and the extension of its influence.

There comes a time in the history of many such associations when enthusiasm dwindles, and sentimental or political discussions no longer draw crowds of eager debaters. Then the rent of halls, and the very cost of postage and stationery becomes too heavy a tax on the remainder, if remainder there be. All over the world, how many societies were founded for national or educational purposes, which enjoyed for a time more or less influence on public affairs, and then passed away!

But the Australian Natives' Association, though interest in public affairs may flag, can never die. Its halls are hired, its postage paid by the business department. In every locality where a branch is established, it begins to accumulate wealth. Twelve or fifteen pence per week, from perhaps twenty members, soon mounts up, and those twenty members do not fail to keep up their payments merely because they have become tired of affirming that "this branch resents the interference of France in the New Hebrides." 
The weekly levies are funded according to an act known as the Friendly Societies Act, a portion being available for management. From this portion, a fee-not extravagant, but still a fee- is set aside for the secretary, and this stipend some pushing young man is glad to earn by a few hours' night work each week. So, when the Australian Natives' Association wakes up to the importance of some national question, it finds the hall open and lighted, and its stipendiary secretary waiting to receive the orations of young Australia.

Many of the branches become the possessors of a few hundreds of trust moneys, which they invest in local property. The management of these funds, and of the property, affords congenial occupation to a few, and it generally happens that the secretary is not entirely alone when the orators of young Australia arrive. Each branch sends two delegates to an annual conference, at which a board of directors and a president are elected. This conference is the parliament of the association, and the young men with political aspirations contrive to be chosen as delegates. Its agenda is a pamphlet, the president's address is a volume, and the debates would, if published, fill an ordinary library shelf. It is not all empty talk, for the professional Australian native, in the main, is a practical and sensible person. He is certainly a person to be reckoned with, just as the association to which he belongs is a force in Australian affairs. Delegate to the conference 
to-day, the year after next he may easily be a Cabinet Minister.

The intending member must declare that he was born in Australia, or at sea en route to Australia. The association has frequently been assailed because it rigidly excludes all persons born in other lands. "I came here of my own free will," deciared one who had been pronounced without the pale. "Am I not therefore a better lover of the country? I came by choice, not by accident of birth." "To which a prominent "native" replied: "The prophet of old worshipped with his windows open towards Jerusalem, and in Australia, when English, Scotch, and Irish folk speak of 'home,' they mean some part of the United Kingdom. They worship with their windows open toward Jerusalem."

The Australian Natives' Association method of fostering a national spirit is therefore to deal at first hand with the native-born, who have no mental or emotional reservations in favour of some green land across the sea. The title of the organisation is so confusing that at least one historian of Australia, writing from his chair in the British Museum, allowed himself to comment upon the enthusiasm of the Australian aborigines in the cause of Australian unity. He was so far right that the membership of the association is not denied to the autochthonous Australian, but diligent inquiry has failed to procure evidence of even one aboriginal member. 
The founders of the society had another reason for confining its membership to those of native birth. It is an excellent reason from a business point of view, and has to do with the sick and funeral fund. In a country newly settled, the native born are all young, with the prospect of long and healthy lives before them. This was the case with Australia when the Australian Natives' Association was founded. Its members were recruited from among the hale youths of the first generation of the Victorian born, the best possible constituency for a benefit society. The men who wanted to build up a sound and substantial funeral fund displayed astuteness in passing by the elder men born in Great Britain, who were not only less whole-souled in their allegiance to Australian ideals, but less eligible as benefit members.

Among the functions of the association is the celebration of the Australian national holiday. This is Anniversary Day, the commemoration of the landing of Captain Phillip on January 26, I788. Accordingly, the Australian Natives' Association holds its annual fête on each 26 th of January. Prizes are offered in all departments of art, literature, and athletics. The budding singers, musicians, and artists of Australia compete in one part of the Melbourne Exhibition Building, while foot and cycle races are going on in the arena outside. There are prizes for reciting, prizes for debating, and prizes for liter- 
ary composition, in prose and verse. The organisation of this annual celebration is carried out in the practical and effective manner that characterises the whole management of the society, and certainly points to considerable business ability among its controllers.

Many of the branches reproduce this fête on a smaller scale, especially those existing in country towns of the second rank. In such places, the association is a centre of social activity, holding debates, concerts, dances, and other functions, contributing largely to the amusements of the little community. The chief of these functions is undoubtedly the competition, which interests the parents and friends who form the audience, as well as the young people who take part in it. Beginning in a modest way in Melbourne this association has now extended its influence throughout Australia, although its chief stronghold is still in the State of Victoria. Its membership is open to both sexes, and while officially denying partisanship with any creed or party, the association itself has become at once a creed and a party. When the proper time came, it was able to render assistance to the cause of Australian unity, a cause reflecting the very spirit of the founders of the society.

The most serious obstacle to Australian unity was the state rivalry already referred to, and this was only overcome by the expedient of referring the question to the people for settlement. The 
result of the popular referendum showed that a large majority of Australians were in favour of federation, although the minority in opposition cannot be described as negligible. Serious difficulties in the way of a complete federation were found in the differences in the development of the separate states: some had borrowed more freely than others, some had parted with a larger proportion of the State lands, or had exploited their mineral wealth more fully, and, finally, the states with small populations were in fear of being dominated by those more populous. For these reasons, the Federal Constitution defines the functions of the Commonwealth Parliament in detail, and expressly declares that all other functions belong to the State Legislatures. By amending the Constitution, the Commonwealth Parliament is able to increase the functions it at present exercises, and so to diminish the functions of the State Parliaments.

This is not very interesting, perhaps, but it has to be understood if the change in Australian life wrought by the federation is to be appreciated at all. The State Parliaments still exist, and still retain most important functions. The number of members in each State Assembly is disproportionately large, although reductions have been made in most State Legislatures since the accomplishment of federation. The member of a State Assembly may represent but a few hundred voters, spread over a sparsely populated 


\section{National Life in Australia 24I}

district, with insatiable requirements in the matter of bridges, schools, and post-offices. His constituents are continually urging these requirements upon him, and it too often happens that the State member considers his electorate first, and the interests of Australia last.

The Commonwealth House of Representatives affords a striking contrast. It contains fewer members than the Legislative Assembly of New South Wales, but some of these members represent electorates larger in area than the United Kingdom, since the number of representatives returned by each state is proportionate to its population. Thus Western Australia, with an area of nine hundred and seventy-five thousand square miles, returns only five members to the House of Representatives; while Victoria, eighty-eight thousand miles in extent, returns twenty-three. The Senate, on the other hand, contains an equal number of members from each state, and serves to guard the less populous states from being overruled by those older and more powerful. From the very outset, the meeting and deliberations of this Parliament had the anticipated effect of broadening the Australian outlook. For the first time, the requirements of tropical Australia were considered in conjunction with those of the temperate South; East was balanced against West; and young Australia realised with a gasp how vast were the considerations affecting national life. It was a heavy blow $x 6$ 
directed at provincialism, but provincialism is dying hard.

A striking example of the conflict between national and state interests is afforded in the question of fixing the site of the proposed Australian capital - a question still unsettled at the time these words were written. The proposal to build a new capital city in one of the most favoured parts of Australia was welcomed by all, both as a means of compromise between the rival claims of Sydney and Melbourne, and because it would create a national centre apart from the influence of any State section. It was, therefore, provided that a site should be chosen in the State of New South Wales, at least a hundred miles from Sydney, and with a minimum area of one hundred square miles, for the creation of a Commonwealth capital. When the question of determining the site came before the House of Representatives, the members representing the State of New South Wales made an endeavour to have a place called Lyndhurst, one hundred miles north of Sydney, chosen for the capital. The attempt failed, and selection was narrowed down to two places both equidistant from Melbourne and Sydney. One of these is Tumut, on an elevated plateau inland; the other Bombala, near the coast and communicating with the seaport of Eden, on Twofold Bay. In the House of Representatives, where the vote of the New South Wales and Victorian delegates preponder- 
ates, the choice fell upon Tumut, possibly from the fear of creating at Eden a rival port to Sydney and Melbourne. When this choice was referred to the Senate for approval, Bombala was at once substituted for Tumut, the explanation being that the less populous and more distant states naturally wished the capital to be near a seaport town, and were able to give effect to their wishes in the Chamber where all states have equal representation. Parliament was soon afterwards dissolved without the dispute having been settled, but the incident is recounted here as showing how the old State rivalries still affect national questions, and also the safeguard to the less powerful states constituted by the Senate.

The creation of a Federal capital, where no State influence is paramount, suggests fresh possibilities to the Australian, and especially to the Australian of the bush, who has been for so long ruled for the benefit of the capital of his state. The idea of an undertaking entered upon, not for the good of Brisbane, or Sydney, or Adelaide, but for the good of Australia, is a new one, but it is none the less pleasant. Perth, the capital of Western Australia, has no railway communication with the Eastern States. The people of Western Australia might build a line, reaching to the border line of South Australia, without in any way ameliorating their isolated position. South Australia is intent upon a line connecting Adelaide on its southern coast with Palmerston 
in the north, and in the meantime is unwilling to extend railway communication westward and join hands with its neighbour there. Before the Federation it would not have been possible to move the South Australians from their position, but the question has now become one to be decided on its national merits by the national Parliament.

The provincialists in Australia have watched the growing prestige of the Commonwealth Legislature with dismay. In the third year of the Commonwealth, motions were tabled in some of the State Parliaments affirming the desirability of secession, and were promptly laughed into oblivion. Enthusiastic gentlemen who have organised secession movements in the capital cities have been regarded in the light of amiable farceurs. It has now become certain that the aspiration after national life was no momentary enthusiasm of the Australian people but a deep-rooted sentiment, and it is to the national Parliament that the Australians look to free them from the financial embarrassment resulting from many years of State maladministration.

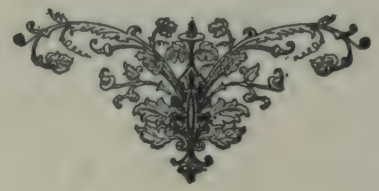




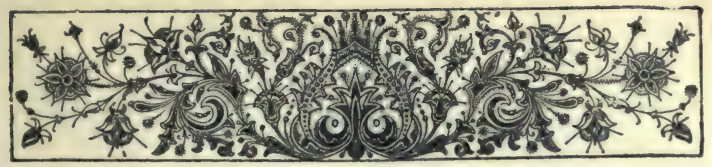

\section{CHAPTER XX}

\section{THE AUSTRALIAN}

COME time ago a London paper published, as $\checkmark$ a seasonable supplement, a coloured picture entitled Christmas in Australia. It represented a bearded man in red flannel shirt, and top-boots, sitting alone in a log-hut, grasping a large packet of letters. His eyes were closed and he was dreaming. Lest this fact should 'not be sufficiently obvious, one corner of the picture was given up to the representation of his dream. It was the home of his boyhood: outside, the snow was thick upon the ground, but within, the family circle was gathered around the cheerful fire. Venerable parents, golden-haired daughters, and manly sons were effectively grouped, but one vacant chair marked the fact that the family exile was not forgotten.

It is not the fault of the average Briton that the man in the red shirt represents his conception of the Australian to-day. The globe-trotter is not alone responsible for the notion that the people of Australia are "more English than the English," and that native-born Australians, who 
have never seen the British Islands, are nevertheless accustomed to speak of them as "home." The impression is confirmed by many of the Australians who visit England, and especially by the Australian politician whose eloquence is inspired by the theme of colonial loyalty, and the absentee landlord who spends in London the income derived from his Australian possessions. These people are largely responsible for the fiction of the "colonist" whose interests, as well as his allegiance, are altogether in the keeping of the Motherland.

The real Australian is no unwilling exile. The day is not far distant when an Australian paper will publish a companion picture entitled Christmas in England. It will show a tall, lean, clean-shaven man, correctly and uncomfortably clad, cowering over a dull fire in a Bloomsbury boarding-house. It is midday, though the gas is lighted, and he has just discovered by a visit to the street door that there is an inch of slush on the pavement, and that fog prevents his seeing across the narrow street. So the Australian falls a-dreaming. His first dream-for he has many -is of a tree-dotted plain, warm with joyous sunlight. So far away as the eye can carry through the pure clear air, the skyline ends the day in a low blue rampart of hills; but his imagination ranges far beyond those to the very centre of the vast unknown continent that is his birthright. Yes, and though the dreamer see as many visions 


\section{The Australian}

as the goblins showed to Gabriel Grub, not one of them but shall concern his own Australia.

There is nothing in this Australian attitude that is inconsistent with the loyalty to Imperial ideals that Australia has proved by more than mere words. The most aggressively Australian paper in the whole continent is careful to explain that it is not anti-British, but only pro-Australian. The ordinary Australian finds it easy enough to be pro-British and pro-Australian at one and the same time. From the Imperial as well as the Australian point of view, this is a distinct advance upon the days when it was correct for Australians to be pro-British only, and to disparage all the things that they termed "colonial." The reaction was inevitable in time, but it has come about without any weakening of the race sentiment that is the strongest tie between the Colonies and the Motherland. This desirable consummation speaks eloquently of the wisdom and sagacity of Imperial administration, as well as the common-sense that is so strong a characteristic of the Australian.

The seasons, the climate, and the fauna and flora of Australia are all united in one conspiracy against the Australian remaining "more English than the English." I can still remember that the most pronounced effect of the British books and poetry I read when at school was to convince me of the unreality of literature. "Chill October" was to me the gladdest month of the year, when 
the bush was flecked with light and deep yellow, and the aromatic air was fragrant with all woodland smells. Even in the city streets, the groves of eucalyptus trees were swarming with honeyquesting parrakeets, that flashed screaming from one blossom-laden tree to another like living jewels. Why, then, did the poet write so sadly of chill October?

Tom Brown's Schooldays was more interesting, but those schoolboy heroes played football with a brazen disregard of all rules, as we knew the game. (Later on, I found it difficult to reconcile an acquaintance with the history of Rome, Greece, and England with my total ignorance of the history of my native country.) All reading, all learning, had to be accompanied with a set of mental adjustments. If the native-born Australian is to be accused of scepticism and irreverence, it must be said in his behalf that he was accustomed from his childhood upwards to read and be taught things that, in the circumstances, were misleading, and untrue. Teaching is better now, and text-books are specially prepared for the Australian schools. The children so educated are the less likely to speak of Great Britain as " home."

More than eighty per cent. of the present inhabitants of Australia were born there, and very few of these can expect to have the opportunity of making the twelve thousand mile journey to the Motherland. Not only is Australia far dis- 


\section{The Australian}

tant from the centre of Empire, but it occupies the most isolated position among all the continents. As a result of this isolation, the Australian has a tendency to become too completely engrossed in local affairs. The Australian Press, more cosmopolitan than the Australian people, devotes a large amount of space to the outside world, and still contrives to leaven the selfabsorption of the Australian. But the pride and patriotism of the native-born have been focussed by the last step taken, when provincialism was renounced for a national life. He is now inclined to think so well of his birthplace that he plans to keep it entirely to himself, and raises a cry of "Australia for the Australians," not "Australia for the white man," nor "Australia for the Empire," let it be observed. In a recent conversation with an Australian friend, who was paying a visit to London, I obtained from him a curious admission. "As far as I can see," he declared, "Australia has nothing whatever to learn from Great Britain, but there is much that Great Britain might learn from Australia." The speaker was an able journalist, occupying a responsible position, and in the Australian sphere of life anything but a narrow-minded egotist. And his attitude, extreme though it be, is surely preferable in every way to that of the Australians of a generation ago, many of whom were highly gratified when some polite person would feign to mistake them for Englishmen. 
The restlessness which forms so dominant a key-note to Australian character is obviously inherited. The founders of the race were men of enterprise and adventure, drawn across the seas by tales of a new land with possibilities indefinitely wide, or by dreams of easily won gold. As one of the Australian poets ${ }^{1}$ has written:

Our fathers came of roving stock That could not fixed abide, And we have followed field and flock Since e'er we learnt to ride. By miners' camp and shearing shed, In land of heat and drought, We followed where our fortunes led, With fortune always on ahead, And always further out.

The Australian is consequently a man of many places, and of many occupations. He will abandon his settled avocation and assured income at a moment's notice in order to enter upon a new life that seems to afford possibilities of increased prosperity. He can become prospector, company promoter, journalist, or trader in turn, in the end to fall back upon his original occupation. Even his own great continent of three million square miles does not contain him, and at the hint of prosperity elsewhere, he is off to South Africa, or Argentine, or any other spot far enough away or little enough known to hold attractions for him.

${ }^{1}$ Mr. A. B. Paterson. 


\section{The Australian}

The lust of wandering takes possession of him, and on a reasonable excuse he must gratify it.

This restlessness is accentuated by the uncertainty of the conditions under which he lives. Change meets the Australian at every turn: he never knows what a year may bring forth. Two good seasons convert the land into a smiling paradise, gladdening the eyes of man with pictures of easy prosperity and happy animal life. Two dry years make it a desolate hell, horrible with sights and sounds of dead and dying animals : unsightly, forbidding, and altogether sordid. The year's work of the settler is at the mercy of the seasons; he lives for ever in dread of drought, flood, bush fire, and those plagues of rabbits and locusts that are continually descending upon him. The cities, too, are quick to feel the pinch of bad seasons, with their consequent scarcity of employment and increase in the price of commodities. Therefore every Australian State has its percentage of floating population that flies at the approach of "bad times" to seek easier conditions within the borders of a neighbouring State.

This uncertainty has bred in the Australian a taste for speculation and a fine courage in the face of adversity. He has learned to count the risks, and makes an excellent loser. To have planned and toiled for nothing is but part of the game of life, and a fresh start must be made with a stout heart, and as often as not with a jest 
upon his lips. But the Australian counts his possible gains as well, and in this respect is gifted with a vivid imagination. $\mathrm{He}$ is not always a good winner, being easily puffed up by the first breath of prosperity. Land booms, mining booms, and even booms in butter and sugar production are the frequent result of this over-confidence, and the effects of the bursting of an Australian boom are fraught with an infinity of disaster. When such calamities occur, it is impossible to avoid a feeling of wonder at the extent to which men reputed shrewd and far-seeing have allowed themselves to become involved. It is equally impossible to refrain from admiring the courage and self-reliance shown by men approaching and past the middle age, in marking out for themselves fresh careers, and facing once more the vicissitudes of life in surroundings so inconstant.

This familiarity with misfortune makes the Australian tolerant and sympathetic. Where prosperity is so often the result of circumstances rather than merit, poverty is not so hastily set down as the sign of either lack of industry or ability. Men speak of their reverses with a ready frankness that betokens an absence of fear of condemnation, and recount their successes with an equal readiness. On this score, the Australian lays himself open to a charge of boastfulness, and those who fail to understand his interest in his neighbours as well as in himself may readily 
be pardoned for holding that view. But the friendliness and helpfulness of the Australian, when once experienced, are sadly missed by those who are afterwards called upon to encounter the reserve and suspicion of older countries.

Underlying the Australian's breezy communicativeness there is a strange vein of shyness, and his tolerance and friendliness are tinged with a scepticism and cynicism not entirely youthful. His shyness he strives to conceal by bluster, his scepticism is made evident by his readiness to find fault. "If Patti came to Australia," declared an exasperated entrepreneur, " they would set about criticising her at once." Quite right, that is the first thing they would do. There is no place in the world where an outside reputation is of less value than in Australia.

The things that never happen, and the things that never could,

Are engraved upon the tombstones of the men who never would,

says one of their verse writers, and, with some exaggeration, sums up the first Australian attitude towards everything not yet proven in Australia. This attitude is not infrequently the prelude to an appreciative acceptance that compensates, by its fulness and warm-heartedness, for all preliminary doubts. When once convinced, the Australian knows no half measures in his appreciation. 
Life in Australia, and especially in the Australian bush, is made attractive by the existent spirit of comradeship. Staunchness is the pet virtue of the man of the bush, and the deadliest $\sin$ in his moral code is committed by the man who " turned dog" upon his mates. "Mate" is the most engaging form of address in the bush, just as "Mister" denotes aloofness tinged with no little suspicion. Services that money could not buy are rendered willingly and cheerfully by neighbour to neighbour, and that without any loss of the feeling of independence that is the bushman's most treasured attribute. It is curious to notice how completely this feeling of comradeship has been accepted throughout the bush. The solitary swagman is at considerable pains to account for the absence of his "mate," whose existence somewhere is regarded as the natural complement of his own being. Two such mates may work the country together, sharing good and evil fortune alike. Each may be ignorant of the other's life story, and even of his very name,-for nicknames and contractions do much hard service in the bush,-yet all their interests and possessions are in common. Not infrequently one man may obtain a few days' work where the other can find none, when his mate will camp close at hand, and the money earned will be regarded by both as a common possession. Acquaintance with a bushman's mate constitutes a strong claim upon his ready and immediate friendship. The man with. 
out a mate is a " hatter," an eccentric person who cannot be quite right in his head.

No sketch of the Australian character could be made without reference to Australian political belief, for, as already shown, politics are a large part of the everyday life of Australia. Nowhere in the world is there a more thorough belief in the efficacy of State intervention. The Australian pays his politicians, and is accustomed to lay all his misfortunes at their door. He knows no foreign questions, and many matters that are elsewhere burning questions have already been settled for him. It was said that during the Commonwealth elections of 1903 each state was agitated by a different question, the issue in Queensland being fought on lines entirely remote from those affecting Tasmania. In the absence of broad dividing principles, the Australian applies to his politicians the test of his own convenience and prosperity. A misplaced school, or a bridge unbuilt, has cut short the career of many a promising politician. Good seasons and prosperous conditions mean long-lived administrations and political indifference; but when bad times come, they bring rapid changes of Government and much political fervour. At such times, the Australian approaches the ballot-box in a spirit of sanguine pessimism, determining to give the other side a chance, in the forlorn hope that his ideals of government may yet be realised. This introduction of the speculative spirit into the realm of politics shows 
the Australian in all his weakness, and his cheerful endurance of the calamities that follow only partly justifies him.

Living in the almost continual presence of sunshine, the Australian is naturally cheerful and good-humoured. Although subject to change, his life holds no extreme of poverty and want, no abyss into which he may be plunged without the possibility of emerging. The signs of hardship and suffering are not always before his eyes, nor has he to contend with the class distinctions that serve elsewhere to advance those who are already "up," and deter those who are "down" from rising. He learns initiative from observing that those who have risen owe their success to opportunities deftly seized, while courage in the face of failure is his unalienable birthright. Each of his fellows is potentially an easily made friend, charitable of his failings and appreciative of his virtues. Circumstances and surroundings have combined to create of him an industrial Bohemian, with the Bohemian failings of thriftlessness and lack of prudence. With borrowed money, he has provided his big cities with every modern convenience of necessity and luxury, and with borrowed money, constructed long railways in order that they may be fed by the country behind them. Now, just when the prospect of a broader national life lies open before him, he finds his revenues consumed by the heavy burden of interest these developments have entailed. How the Australian 


\section{The Australian}

will win through the difficulties immediately before him will be interesting to see, but that he will win through them nobody who appreciates his individual courage, energy, and resource can doubt.

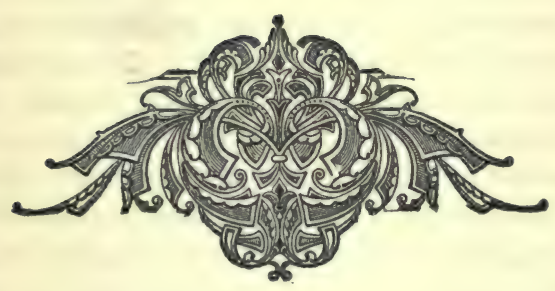




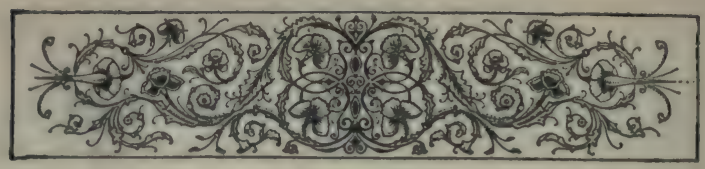

\section{CHAP'TER XXI}

\section{INDUSTRIAI, PIONEERS}

THE coming of the white man to this continent of the Southern Seas is an oft-told tale, but not without its constituents of romantic and heroic interest. Any close examination of the details of Australian discovery would be out of place in a book concerned with the past only so far as it affects the present. The outlines of Australian history, however, compel some attention, since the means by which the country was populated is largely responsible for the character and distribution of the Australian people to-day. The beginning of Australia was a legend, due no doubt to an unrecorded discovery made by some long-forgotten adventurer. Certain it is that early in the sixteenth century, the geographers of the time agreed that somewhere in the Southern Seas there was a great unknown land of mystery. The map-makers of those days dotted this great South Land on their maps of the world, varying its outline and dimensions, each according to his own fancy. In 5598 , we find the Dutch historian Cornelius Wytfliet writing of it: "The Terra 
Australis is the most southern of all lands, and is separated from New Guinea by a narrow strait. . . The Terra Australis begins at one or two degrees from the Equator, and is ascertained by some to be of so great an extent that if it were thoroughly explored it would be regarded as a fifth part of the world."

Within a few years, Torres confirmed part of this guess-if it were a guess-by sailing between New Guinea and the mainland of Australia by the strait that has ever since borne his name. Then came the Dutch, who discovered Australia as far as the history of the land can tell. Tasman, most intelligent of ocean explorers, found Tasmania, which he named Van Diemen's Land after his patron, and New Zealand, which still bears the curious Dutch name he gave it. Indeed, Australia was known in the seventeenth century as New Holland, and had considerable difficulty in shaking off the name. Thus a good deal was known about the great South Land before the first Englishman landed on its shores. He was William Dampier, a genial pirate, who wrote of his adventures with such engaging interest that he attracted much English attention to the new country. On a second voyage to Australia, undertaken in 1699 in the Admiralty vessel Roebuck, Dampier found that the new country offered few attractions to him, for he was a picker-up of unconsidered trifles rather than an explorer. 
More than half a century later came Captain Cook, the most accurate, painstaking, and scientific explorer the world has ever known. The conclusion of his remarkable life-work left little more to be learned about the Australian coast, and that little was carefully and well investigated by men who had the advantage of acquaintance with his methods. On the scientific side of Cook's expedition was Sir Joseph Banks, whose enthusiastic account of Botany Bay remains to this day as an apt illustration of the deception practised by Australia in her most winsome moments. The worthlessness of the land at Botany Bay, which appeared to Banks an earthly paradise, was soon discovered by Governor Phillip, and to this day it remains barren and unproductive. But it is well that Banks formed such a glowing opinion of the new country, for his advocacy had no little weight with the Government that first attempted the colonisation of Australia.

The long discussion that ended in the despatch of Captain Phillip to establish a penal settlement in Australia may well be passed over. It should be said, however, that the early advocates of the colonisation of Australia did not even include a convict establishment in their scheme. That was added by a Government hard pressed to dispose of its malefactors, and in time the Colony became a penal establishment, and little else. Captain Phillip landed at Port Jackson January 26, 


\section{Industrial Pioneers}

I788, a date that is now annually celebrated in Australia as Anniversary Day. He was only a few days ahead of a French expedition, commanded by M. de la Perouse. Had Phillip been a week later he would probably have found Australia in the hands of the French, and it would be necessary to write the history of the continent after quite another fashion. For many years after the landing of Governor Phillip, Australia remained a convict settlement. It was ruled with an iron hand by prison governors, who looked with disfavour upon any free settlers who might come there, and deliberately stifled any attempt to enlarge the area of settled country by exploration. But during those years, one man at least was working steadfastly for the prosperity of his adopted country. Captain John MacArthur was a member of the New South Wales Corps, a military body raised in England for service in Australia. MacArthur belied his military training by a sure instinct in matters both agricultural and pastoral, and seems to have grasped the pastoral possibilities of Australia immediately upon his arrival there. $\mathrm{He}$ was fortunate enough to obtain from Cape Colony a few of the merino sheep that had long been one of the most jealously guarded possessions of Spain, and with these he began sheep-breeding on scientific lines. The result of his experiments was a wool-producing sheep of a character different from that of the Spanish flock, but bearing a fleece of equal 
quality. He was granted a large grazing area to carry on his experiments, and encouraged by the interest of Governor King, who then ruled the Colony, his flock increased wonderfully. Within a century, those few Spanish sheep smuggled away to Australia were represented by flocks numbering more than one hundred million, spread over the pastures of the whole continent.

Captain MacArthur was the father of the pastoral industry of Australia, and his efforts were splendidly aided by the work of the explorers. North, south, and west, they pushed, over the rugged peaks of the Dividing Range into the strange unknown country beyoud. They followed the great inland streams of New South Wales to their junction with the river Murray, and, so to their outlet in the sea. They crossed the desert plains of the interior, and the fertile plateaux of south-eastern Australia, always on the look-out for land suitable for settlement. Wherever they went the hardy band of free settlers followed, glad to escape from the ferment of the penal settlement on the coast. Some of the explorers lost their lives in their bold endeavours to penetrate the unknown, while others returned to safety after performing deeds of heroism and endurance that seem to have been well-nigh miraculous. The practical value of their work was shown by the expansion of the pastoral industry during the first half of the nineteenth century, and by a progress in settlement that enabled 


\section{Industrial Pioneers}

Australia to reap a full advantage of the golden awakening that was to follow.

The discovery of gold did not take place until 185I, but rumours of the existence of the precious metal were current long before that date. The search for it was steadily discouraged by the Government, which feared the effect of so unsettling a discovery upon the population, then largely composed of convicts. But the golden discoveries made in California in 1848 drew attention to the possibilities of Australia, and it was inevitable that the secrets still held by the soil must sooner or later be brought to light. The instrument of the discovery was Edward Hargraves, a New South Wales settler who had been attracted to the Californian coast by the tales of treasure to be dug out of the earth in hatfuls. Hargraves got little gold in California, but he got an idea which afterwards proved highly profitable to him. He was quick to notice how the gold-bearing regions of California resembled country he had seen in New South Wales, both in the characteristics of soil and of rocks, and he argued that gold would probably be found in such country in Australia. Thither he returned, determined to verify his conclusion. $\mathrm{He}$ has left an interesting account of his find. He determined to "prospect" in Summer Hill Creek, a tributary of the Macquarie River, and he met with success almost at his first trial. On February $12,185 \mathrm{I}$, he found alluvial gold at this spot. 
In the greatest excitement, he turned to the bushman who accompanied him, and explained the consequences of their find. "I shall be knighted, Bill, and your name will get into the papers. As for our old horse here, when he dies they '1l stuff him and put him in a museum." The prophecy was a lame one, for none of these things happened. But Hargraves earned by his discovery a Government reward of $£ 10,000$ and a Government position as Commissioner of Crown Lands.

When Hargraves's discovery became known to the outside world, there followed such a rush of immigrants as Australia had long needed and desired. They came from all quarters of the globe, brave, enterprising men well fitted to be the ancestors of a new race. Some of them were little suited to the work of mining, and soon dropped into the callings they had followed before their pilgrimage to Australia. Many settled on the land, or in the towns that grew up about the richest mining fields of the country. Some returned in disgust to the Old World, which they had left with such high hope of fortune's favours. But the access to the population was enormous. Victoria alone gained a quarter of a million people in five years, and nearly all of them pioneers of the finest type. Younger sons of noble houses rubbed shoulders with enterprising tradesmen, adventurers from every corner of the earth worked side by side with stolid miners from Cornwall and Lancashire. But they all had the 


\section{Industrial Pioneers}

saving grace of imagination, that brought them so long and dangerous a journey across the seas in search of the wealth of Eldorado.

Cities grew up as if by magic. Not many years before, John Batman had found on the banks of the river Yarra what he declared was a fine site for a "village." Melbourne rose on the village site, and in half a century was a city with a population of half a million. The " roaring fifties" are still remembered as the days when Australia held a prosperity never equalled in the world's history, and a touch of romance as well. The gold fever never passed away from the land. It is there still, as I hope presently to show. But the fury of gold-seeking passed away, and the red-shirted miners became peaceful farmers, or prosperous tradesmen and mayors of country towns. Gold-mining became simply a trade, although a trade from which the element of romance could never be altogether dissevered.

Twenty years later, Australia had another burst of prosperity, though it was a fictitious prosperity, as it is easy enough to see now. It was created by the lavish expenditure of borrowed money on public works of all kinds, and on commercial enterprises of a private nature as well. The country experienced a series of "booms." Money invested in silver mines inflated these to many times their real intrinsic value; money invested in land caused extravagant prices to be paid for worthless allotments in remote city 
suburbs. It was an era of frantic speculation, and it ended in a collapse from which only a highly recuperative country could ever have recovered. A recital of the successive calamities that struck Australia during the ultimate decade of last century would read exceedingly like the first chapter of the Book of Job. A great industrial conflict paralysed the shipping, mining, and pastoral industries, and dislocated the whole business of the continent. It was followed by a financial crisis. Banks closed their doors, thousands and tens of thousands were ruined, and the country was plunged into a commercial stagnation from which it has only now recovered. Then came the drought; and it came to stay. The pastoral history of Australia knows no other drought like it, for it lasted for ten years. Many pastoralists concluded that it was a permanent drought, and either by choice or necessity abandoned their pastoral holdings. It swept away half the animal life of the country. No one will ever know what it cost Australia. One illustration only may be supplied. The wheat crop of Australia for 1902-1903 - the last of the dry years -was worth $£ 2,000,000$ in round figures. Next year, from a smaller area of cultivated ground, wheat worth $£ 12,000,000$ was harvested. Wheat, of course, is only one product among many.

The greatest asset of a new country is population, and it will never be known what Australia lost in this direction by the drought. The popu- 
lation of the continent rose from two million to three million in eleven and three-quarter years. But it has taken more than sixteen years to increase from three to four million, the present population. The position would have been worse but for an opportune discovery of gold in Western Australia. An outlet for the restless surplus of unwillingly idle people was found in the continent, and while the rest of Australia was languishing, Western Australia expanded in the rays of a golden sun of prosperity. But the continent could not be bolstered up for long on the basis of gold mines, and would have fared exceedingly ill but for the genius of one man, whose name is still unknown to many Australians.

Some day Australia will build a national Walhalla-perhaps in the bush capital of the Commonwealth-to hold the statues of its departed great ones. John MacArthur will be there, no doubt, and Hargraves, as well, for these are the pioneers of two of Australia's greatest industries. My third worthy is James Harrison, who first experimented in the ocean carriage of perishable produce. Harrison was a journalist-when he was not an inventor-who lived in the sleepy little town of Geelong, near the entrance to Port Phillip Bay. The State of Victoria at that time was trying to dispose of the surplus products of its agriculturists-meat, butter, fruit, poultry, and the like,-by creating a 
home market for their consumption. That is to say, an endeavour, not wholly unsuccessful, was made to create local manufactures and an artisan class by the imposition of heavy customs duties on imported manufactures. Harrison attacked the problem from another point of view. He tried to find some way of getting these perishable products to the empty markets of the Old World without impairing their freshness and value. Among his clever inventions was one for making ice cheaply and in large quantities, and he, too, evolved the idea of the refrigerating chamber. An attempt to put his invention to practical use involved him in financial ruin, but it established the possibility of success.

Harrison failed in the pecuniary sense, and ended his life as a hard-working journalist. But his idea, to which, let it be said, he gave practical form, has meant the salvation of Australia. The Commonwealth has at last found markets for the goods that are most readily produced there, and they are markets without any limit. In 1904, Australia sold $£ 20,000,000$ worth of products in excess of her purchases. Whatever the political economist of Great Britain may have to say to this credit balance, in Australia it is regarded as highly satisfactory. A large proportion of the money was received for products that could only leave Australia in the refrigerating chamber. Cold storage has even shown a solution of the rabbit problem, so long the nightmare 


\section{Industrial Pioneers $\quad 269$}

of the Australian farmer and pastoralist. In ten years, $£ \mathrm{I}, 500$, o00 has been received in Australia for frozen rabbits, and so a pest has been converted into a profit. A modest monument in the Geelong cemetery, erected by a few admirers, and an occasional reference in the Press are all the tribute Australia pays to James Harrison. He has deserved better of his country than that.

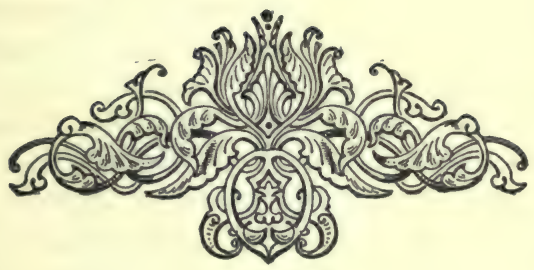




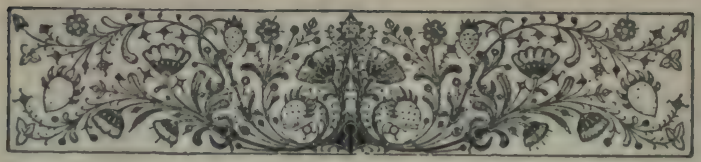

\section{CHAPTER XXII}

\section{AUSTRALIA'S DESTINY}

I HAVE striven to depict the people of Aus1 tralia busy in the work of developing the resources of their country, secure from all outside influences. The generous measure of self-government which they enjoy permits them to manage their own affairs practically in their own way. The remoteness of their continent, as well as the protection of the world's greatest sea-power, has so far ensured their immunity from outside interference. For more than a century, they have worked on undisturbed. The Old World has been torn by wars and revolutions, yet these have meant no more to Australia than so many extra columns of interesting reading matter in the newspapers. There are many Australians who act as though this golden reign of peace would last for ever.

Yet Australians have had some sharp reminders that their lands are broad and their people few. From time to time, some great European Power has coveted one of the many islands that dot the near Pacific waters, and has 


\section{Australia's Destiny}

not stopped short at coveting. American influence in the Sandwich Islands; German aggression in Samoa, in New Guinea, and last of all in the Marshall Islands; French interference in New Caledonia and the New Hebrides-these incidents have in turn given the alarmists cause to raise their voices. Australian politicians have been untiring and vehement in their protests to the Colonial Office, but the effect of their representations has never been appreciable. The sphere of foreign influence in the Pacific has enlarged by almost imperceptible degrees, and only the other day, the Australian Prime Minister awakened with a gasp to the consideration of sixteen foreign naval stations within easy striking distance of Australian shores. Distance is being annihilated by time, and the remote and peaceful Australian is now confronted by possibilities it was once the fashion to ridicule.

Perhaps the Boer War furnished Australia with its first real reminder that national responsibility must go hand in hand with national ambition. It is not easy for the home-keeping Englishman to grasp the real meaning of the wave of patriotism that swept over Greater Britain during the progress of that struggle. "The loyalty of the Colonies" has degenerated into a phrase for the use of party politicians, who too seldom stop to consider its meaning. Whether the Colonies will always be loyal to Great Britain is a question that may yet have to be decided. 
It is quite certain, however, that they will always remain loyal to the Empire, provided there remains an Empire to excite the passion of loyalty. The Boer War opened with an incident that appealed most forcibly to every Colonial who cherished this ideal of Empire-the invasion of a self-governing Colony by a hostile force. From that time forward, the Australians and New Zealanders-and obviously the Canadians and other Colonials as well-regarded the war as peculiarly their war. It was clear enough to any one who saw much of the men who left their homes to fight in South Africa that this aspect of the quarrel had touched their imagination most keenly. It was the first real Colonial war in which the Empire had been engaged, and the notion of Empire suddenly gained an attractive reality in the eyes of Australians. Even so, perhaps, would Canadians and Africans rally to their help if ever Australia were invaded by an enemy.

From the sentimentalists' standpoint, this view of Australian loyalty is possibly less attractive than the conventional idea of love for "the dear old Mother Country." It is, however, the view consistent with the Colonial attitude on most Imperial questions. Canada still refuses to pay one penny toward the maintenance of the British fleet, simply because it is a British fleet and not an Imperial fleet. Australia with a grudging reluctance contributes the sum of $£ 200,000$ annu- 
ally as a naval subsidy, and New Zealand only pays an amount in proportion. Yet all the Colonies gladly combined to bear the cost of an Imperial line of cable, in the administration of which they were allowed some voice.

These instances of Colonial sentiment and Colonial policy are advanced merely in explanation of the manner in which the Boer War changed the Australian outlook upon the world outside. It brought home at once the reality of the Imperial tie and the unsubstantial nature of the Imperial fabric. It showed, as nothing else could have done, the desirability of an Imperial Federation, and the obstacles that existed in the way of such a Federation.

Australia to-day is halting on the path towards Imperial unity. Rightly or wrongly, the Australian believes that in order to enter into closer relations with the Mother Country he will have to lay aside that striving for race purity which is an instinct with him. Since the Federation of the Australian States was accomplished, the whole history of the world has been rewritten for Australia. A new Power has grown up in the Pacific. In the sudden rise of Japan, the Australian discerns the most sombre menace to all his most cherished ideals. From the Australian's point of view, the position is an intricate and difficult one. Almost in the moment when the Commonwealth was deciding that the Japanese was not a desirable citizen for Australia, and passing legislation to 


\section{4 \\ Australian Life}

exclude him from Commonwealth territory, a stroke of British diplomacy exalted Japan to the position of an Imperial ally. The outbreak of the Eastern war followed, and from that time the Australian attitude towards Japan has been indefinable. The Australians love the Japanese at a distance. They regard them as splendid fighting men, and creditable allies even to the Mother Country. But these facts do not alter the Australian view that the Japanese is an undesirable citizen, whereas the Russian is a desirable one. During the progress of the war, a motion was tabled in the Australian Parliament for the free admission of Japanese into the Commonwealth. It was not granted even serious consideration.

On the other hand, Japanese feeling on the subject is equally unmistakable. The Japanese are not given to parading their feelings, or announcing their plans in advance. But it is certain that their exclusion from Australia is at once harmful to their settled policy of expansion, and wounding to their national pride. It is set down as a matter for attention as soon as more pressing affairs have been settled. Responsible Japanese statesmen have openly said as much. Japanese merchants who have business relations with Australia are never tired of referring to their grievance, even in business correspondence. The injury crops up in every pearlers' quarrel at Thursday Island or on the north-west coast of Australia, and the angry Japanese coolie does not 


\section{Australia's Destiny}

hesitate to threaten his white rivals with what will happen as soon as Japan is able to take in hand his grievances. Australians also remember how, not very long ago, they entertained a Japanese fleet in their harbours. The visitors were made much of, and fêted at every port, so that they were able to see whatever was to be seen. No Australian who has ever given two thoughts to the matter doubts now that the Japanese information as to the sea gates and fortifications of Australia is full and complete. Possibly they credit their visitors with powers of observation greater than they possessed, but the history of the Manchurian campaign proves that the Japanese Intelligence Department has never yet neglected an opportunity so favourable as that afforded by the easy Government of the Commonwealth.

No doubt the Australian takes an alarmist view of the situation, but it must be remembered that the "Yellow Peril," which is still only a bugbear phrase to Western Europe, is a very near and real thing to him. He is forced to look forward to the day when Japan, as Great Britain's ally, will request that the disabilities under which the Japanese labour in the Southern continent shall be removed, and he cherishes no illusions as to the reply His Majesty's Government will make. He does not believe that the decision will be influenced in any way by Australian sentiment or Australian opinion. Since the day 
when Australians turned British convict ships from their wharves with an open show of force, there has never been a moment when the Imperial tie has been in any danger of severance. But that moment will come should the Commonwealth at any time receive the order to throw open its territories to an Asiatic people.

It is at least certain that Australian life of today is very strongly influenced by this shadow which lies across the future of the continent. Not long ago, Mr. Deakin, who is the most representative of Australian Nationalists, was interviewed on the subject of Australia's relations with the outside world. $\mathrm{He}$ expressed very forcibly the view that the Commonwealth should immediately prepare itself for the defence of its shores. "Australia," he said, "which used to depend largely on its isolation for security, is now within what is termed striking distance of no fewer than sixteen foreign naval stations-San Francisco, Mazatlan, Callao, Iquique, Hawaii, Tahiti, Samoa, New Caledonia, Yokohama, Port Arthur, Shanghai, Manila, Saigon, Bencooelen, Reunion, and Tamatave. It is very doubtful if we are properly prepared to meet a dash at our weak spots, delivered by two or three fast cruisers. It is also very much open to question whether our harbour defences are equal to the test to which they might be put. The forts about our principal cities are most of them of antiquated design, and very dangerous to the 


\section{Australia's Destiny}

garrisons who would hold them under a fire of modern missiles. We require submarines, torpedo boats, and torpedo-boat destroyers. We have enough men for any requisite naval forces, and for the naval reserves a great influx of desirable settlers is necessary all round Australia, with a view to the efficient defence of the whole continent, of which at present only part is occupied.

"When we are attacked, it will not be with kid gloves or after convenient notice, but it will be when and where we least desire it, and with remorseless fury. The very least with which we can be content is such an expenditure and such defence forces as will afford us reasonable guarantees of safety to our ports, our cities, and our coasts."

The significant features of the interview were the omission of any reference to the British fleet stationed in Australian waters and the desire for a great influx of population. The presence of a British fleet in Australian waters is merely a matter of social interest to Australians. They have been told so often that the great naval battle for the protection of their continent will probably be fought many thousands of miles from its shores, that they have accepted the statement as being probably true. They feel equally sure that such a battle will be fought around no quarrel of Australia's choosing. The advocates who from time to time have urged the 
Colonies to increase their naval contributions have employed the very arguments calculated to defeat their own ends. Australia, like Canada, has been led by these enthusiasts to believe that the defence of Commonwealth shores rests with the Commonwealth. The national spirit in Australia contemplates nothing more certainly than that the nation shall be self-protective. Otherwise, says the young Australian, we shall not be protected at all.

But for the efficient protection of so large a country a much greater population is required. On this point all political parties in Australia are now agreed. The most remarkable effect of the apprehension caused by the rise of Japan is displayed in the modification of the Labour programme. Mr. Watson, the Labour leader in the national Parliament, has been quick to recognise the danger of the waste, unoccupied plains of Northern Australia. So long as these fertile lands remain undeveloped, they afford the best possible reason for a demand that Australia should open her ports to coloured labour. Opportunities for growing cotton, and a score of other valuable tropical products, are let slip year by year for want of suitable labour to develop these lands. It is not probable that British immigrants would be able, in such a climate, to do the hard work that is required in a satisfactory manner. The suggestion is now made that immigration should be encouraged from the races of Southern Europe, 


\section{Australia's Destiny}

who are accustomed to perform heavy tasks in a climate approximating to that of Northern Australia. Although this scheme is practically dependent upon permission being obtained to indenture Italian, Bulgarian, or Austrian labourers under contract, it already meets with a tentative support from the Labour party. It involves an important modification of that clause of the Restriction Act which forbids the introduction of immigrants under contract. The Labour leaders are now letting drop guarded intimations that they are prepared to modify this clause in favour of the white labourer from over the seas. Mr. Watson recently stated that people had abandoned the idea that white men could not work on Northern plantations. While not anticipating that there would be any necessity for it, he continued, he would be prepared, under certain circumstances, to consider the necessity for allowing the indenturing of white labour, but it would have to be done under very carefully framed conditions, with an insistence upon the payment of fair wages. "We shall have, I think, to widen our platform," said another Labour leader, "so that people from Southern Europe, who are accustomed to working in hot climates, may be induced to accept the engagement of work in the Queensland sugar fields. The engagements would have to be under Government control. I would even go so far as to agree to a system of assisted passages, on 
condition that the State Governments would undertake to settle the immigrants on land on the completion of their engagements."

The fear of Japanese aggression will have a wholesome effect, if it causes the leaders of the Popular party in Australia to take immediate steps for populating their waste territories. By doing so, they will abolish one reason for outside interference. At the same time, such a step will prevent the coloured man from gaining any firm foothold in Australia, should it be found necessary in the interests of Imperial unity to throw the Commonwealth open to Eastern races. On the other hand, if Australia should see fit to stiffen her back when the time comes, and to insist on the maintenance of a white Australia, the advantage of an immediate influx of white population cannot be overestimated. In America, whither Australia has turned for guidance in the solution of many problems, already presented by her national life, it has been found that the European immigrant becomes Americanised with extraordinary rapidity. This lesson the Labour party appears to have learned; hence the modification of its programme and legislation.

It will be seen, then, that Australia is not entirely blind to the future, as the Australians conceive it. The day may be far distant when Australia will be called upon to choose between Imperial unity and independence. It may never come. But the Australian anticipates that in the 


\section{Australia's Destiny 28I}

near future Japan will press for the recognition of her people to share equal rights in Australia with any white man. What may happen then will be beyond the power of Australia to decide; except upon one point. The present writer meets in London many Australians who have settled down to existence in Great Britain more or less permanently. "Do you ever intend to go back ?" is a question not infrequently asked. Most Anglo-Australians are now familiar with the answer: "Well, I may have to go back some day-to fight."

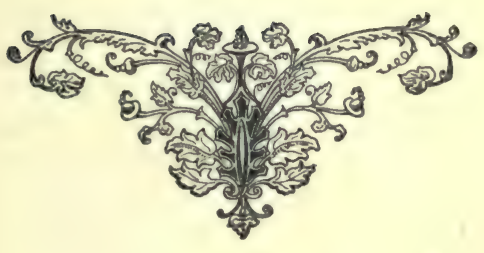




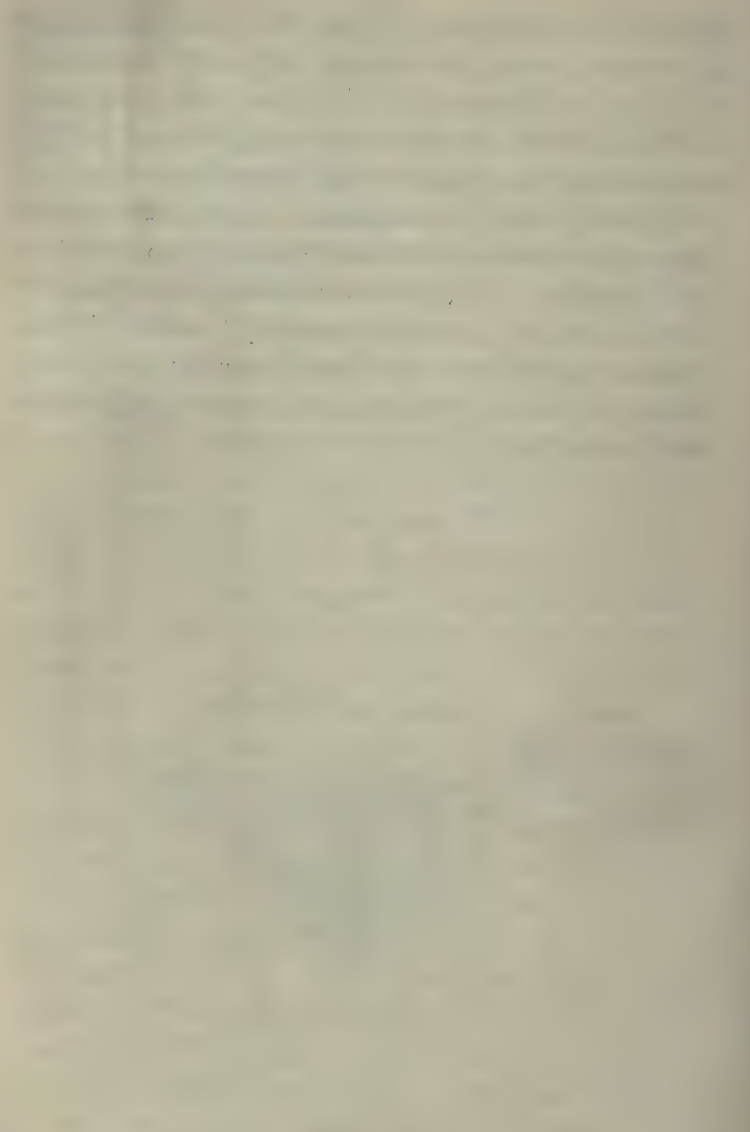




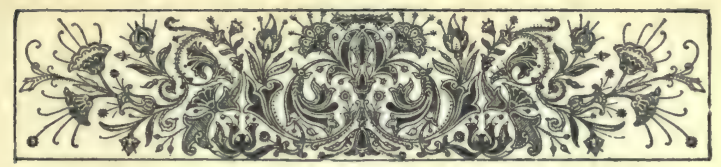

I N D E X

ACCENT, Australian, I6I

Aliens, coloured, II 7, 208

Animals, wild, 85

Anniversary Day, Ir4, 238, 26r

Arbitration, compulsory industria1, I27, I53

Area of Australia, 4

Artists, Australian, 230

Artesian wells, 9I

Australian Natives' Association, 234

"BAGMEN," 72

Ballarat, I34

Bicycles, novel use of, 72

"Billy-can," 75

Birth-rate, declining, I6I, I62

Boer War, $27 \mathrm{I}$

Boundary riders, $2 \mathrm{I}$

"Brownie," 22

"Brumbies," 35

Buckjumpers, $3^{8}$

Buffalo in Australia, I92

Bulletin, the, 226

Bush, aspects of, 8 ; fire in, 51 ; women of, 167

CADETS, military, 222

Camel in Australia, 63, I89

Camping out, Igo

Capital, Commonwealth, 242 


\section{Index}

Capitals of States, 7, I2, 95, I62

Cattle runs, 23

Chinese, the, II7, 210

Christmas in Australia, 3, 50

Churches, 221

Clearing the land, I46

Clubs, 177

Coastline, 4

Cockatoo farmers, 43

Constitution, Commonwealth, 240

Coolie labour, 208

Cricket, $\mathbf{1 8 2}$, 186

Customs, English, 2

Cycling swagmen, $7 x$

DAIRYING, 47

Debt, public, 126

Defence, 222, 276

Dialect, aboriginal, 200

Diet, Australian, I70 ; aboriginal, 198

Dog, native, 197

Dress, 158

Droving, 58

Drought, $66,8 \mathrm{r}$

EIGHT-HOUR day, 128

Empire, unity of, 273

Equality, social, II2

Exclusiveness, class, 175

Explorers, 56

Federation, imperial, 273

Fêtes, national, 238

Fish, Australian, II9

Fishing, I90, I99

Football, I87

Franchise, female, 164 


\section{Index}

Fruit, abundance, of, Iro

GoL,D, discovery of, 263 ; exploration for, $57, I_{34}$

Governor as host, I74

Hor,IDAy resorts, io6

Home life, 169

Homestead station, I7

Horsebreaking, 36

Horses, wild, 35

Hospitality, 2, I79

Hospitals, bush, 79

Housing question, I08

ICE habit, I72

Immigration, 155,278

Immigration Act, I54

Imperial Federation, 273; unity, 273

Irrigation, 90

"Jackaroo," the, 20

Japan and Australia, 273

Japanese, 2I4, 217

KALGOORIIE, I3 8

Kanakas, 2I7

LABOUR leaders, I30, 278

Labour party's origin, I 28

Labour programme, I3I

"Larrikins," I 14

MAGAZINES, 227

Malays, 2I4

Manila men, 214

Meat, consumption of, I7r

Mining " rush," I39

Mirage, 66 


\section{6}

\section{Index}

Music, I62

Mustering cattle, 34

NATIONAIISM, 240

Navy, Australian, 276

Never-Never Land, 7, 55

Newspapers, 225

Novels, 229

OPIUM, abuse of, II7, 205

PARKS, I06

Parliament, Commonwealth, 240

Parliament House, 97

Pastimes, aboriginal, 200

Pearl fishing, 214

Pensions, old-age, 127

Population, increase of, 155,267

Press, 224

Professional men, ro3

Protective tariffs, 12, I52

Provincialism, 232, 239

Public buildings, 97

Public servants, 123

"Push," larrikin, II4

RABBITS, I6, 39

Racing, I8 3

Racing picnic, 26

Railways, 92, 233

Rainfall, 5, 8I

Rations, station, 22, 7o

Refrigeration, 268

Religious teaching, 22I

Rents, I08

Rivers, 5

"Runs," pastoral, 7 


\section{Index}

SALTBUSH, Io, 87

Schools, 48, 220

Secret societies, 212

Selectors, 16, 43

Servants, 160

Sexes, comradeship of, 160

Shanty, bush, 78

Shearers, 29

Shearing machine, I9

Shooting, I9o

Slang, bush, 73

Sports, 50

Squatters, I4

Stampede of cattle, 60

States, division into, 6

Stockmen, 25

Strike, maritime, 128

Suburban life, I04, II9

Sugar-cane, cultivating, 2I0, 217

Swagmen, 49, 69

Swag-rolling an art, 75

TEA, consumption of, I70

Tea-rooms, I04

Tenements, 108

Theatres, 229

Township life, r8o

Trackers, aboriginal, $20 \mathrm{I}$

Transport difficulty, I50

UNEMPLOYED, the, I25

Universities, 224

VINEYARDS, 148

WAGES, 152

Water conservation, 88 
White Australia, r6I, 28o

Wood-chopping a sport, I88

Wool-classing, 32

Wool-kings, I5

Wool-shearing, 29

Working man, status of, I76

Working woman, status of, $x 64$

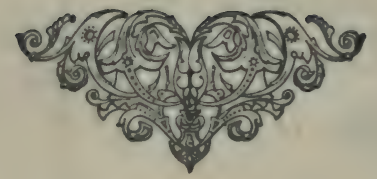




\title{
Our Asiatic Neighbours
}

$12 \circ$. Illustrated. Each, net $\$ 1.20$

By mail - . . . 1.30

\section{1.-INDIAN LIFE IN TOWN AND COUNTRY}

\author{
By Herbert Compton.
}

"Mr. Compton's book is the best book on India, its life and its people, that has been published in a long time. The reader will find it more descriptive and presenting more facts in a way that appeals tn the man of English speech than nine-tenths of the volumes written by travellers. It sets forth the experiences of a quarter of a century, and in that period a man can learn a good deal, even about an alien people and civilization, if he keeps his eyes open. If the other volumes in the series are as good as 'Indian Life in 'Town and Country' it will score a decided success."-Brooklyn Eagle.

"An account of nativelife in India written from the point of view of a practical man of affairs who knows India from long residence. It is bristling with information, brisk and graphic in style, and open-minded and sympathetic in feeling."-Cleveland Leader.

\section{I.-JAPANESE LIFE IN TOWN AND COUNTRY}

By Grorge William Knox, D.D.

"The childlike simplicity, yet innate complexity of the Japanese temperament, the strangely mingled combination of new and old, important and worthless, poetic and commercial instincts, aims, and ambitions now at work in the land of the cherry blossom are wel' brought out by Dr. Knox's conscientious representation. The book should be widely read and studied, being eminently reasonable, readable, reliable, and informative."-Record-Herald.

"A delightful book, all the more welcome because the ablest scholar in Japanese Confucianism that America has yet produced has here given us impressions of man and nature in the Archipelago."-Evening Post. 


\title{
III.-CHINESE LIFE IN TOWN AND COUNTRY
}

\author{
By E. BARD。 Adapted by $H$. TwITCFELL.
}

Every phase of Chinese life is touched on, explained, and made clear in this volume. The nation's customs, its traits, its religion, and its history, are all outlined here, and the book should be of great value in arriving at a better understanding of a people and a country about which there has been so much misconception. The illustrations add greatly to the value of the book.

\section{IV.-PHILIPPINE LIFE IN TOWN AND COUNTRY}

\section{BY JAMES A. IEROY.}

Mr. LeRoy is eminently fitted to write on life in the Philippines. He was for several years connected with the Department of the Interior in the Philippine Government, when he made a special investigation of conditions in the islands. Since his return he has continued his studies and is already known as an authority on the Philippines. His book gives a full description of life among the native tribes, and also in the Spanish and American communities.

\section{V.-AUSTRALIAN LIFE IN TOWN AND COUNTRY}

A bright, readable description of life in a fascinating and littleknown country. The style is frank, vivacious, entertaining, captivating, just the kind for a book which is not at all statistical, political, or controversial. 


\section{Our European Neighbours}

Edited by WILLIAM HARBUTT DAWSON

12. Illustrated. Each, net \$1.20

By Mail . . . . 1.30

\section{I.-FRENCH LIFE IN TOWN AND COUNTRY}

\section{By Hannah Lynch.}

"Miss Lynch's pages are thoroughly interesting and suggestive. Her style, too, is not common. It is marked by vivacity without any drawback of looseness, and resembles a stream that runs strongly and evenly between walls. It is at once distinguished and useful. . . Her five-page description (not dramatization) of the grasping Paris landlady is a capital piece of work. . . Such well-finished portraits are frequent in Miss Lynch's book, which is small, inexpensive, and of a real excellence." - The London Academy.

"Miss Lynch's book is particularly notable. It is the first of a series describing the home and social life of various European peoples-a series long needed and sure to receive a warm welcome. Her style is frank, vivacious, entertaining, captivating, just the kind for a book which is not at all statistical, political, or controversial. A special excellence of her book, reminding one of $\mathbf{M r}$. Whiteing's, lies in her continual contrast of the English and the French, and she thus sums up her praises: "The English are admirable: the French are lovable." "-The Outlook.

\section{II.-GERMAN LIFE IN TOWN AND COUNTRY}

By W. H. DAwson, author of "Germany and the Germans," etc.

"The book is as full of correct, impartial, well-digested, and well-presented information as an egg is of meat. One can only recommend it heartily and without reserve to all who wish to gain an insight into German life. It worthily presents a great nation, now the greatest and strongest in Europe." - Commercial Advertiser.

\section{III.-RUSSIAN LIFE IN TOWN AND COUNTRY}

By Francis H. E. Palmer, sometime Secretary to H. H. Prince Droutskop-Loubetsky (Equerry to H. M. the Emperor of Russia).

"We would recommend this above all other works of its character to those seeking a clear general understanding of Russian life, character, and conditions, but who have not the leisure or inclination to read more voluminous tomes. . . . It cannot be too highly recommended, for it conveys practically all that well-informed people should know of 'Our European Neighbours.' "-Mail and Express. 


\title{
IV.-DUTCH LIFE IN TOWN AND COUNTRY
}

\author{
By P. M. Hough, B.A.
}

"There is no other book which gives one so clear a picture of actual life in the Netherlands at the present date. For its accurate presentation of the Dutch situation in art, letters, learning, and politics as well as in the round of common life in town and city, this book deserves the heartiest praise." -Evening Post.

"Holland is always interesting, in any line of study. In this work its charm is carefully preserved. The sturdy toil of the people, their quaint characteristics, their conservative retention of old dress and customs, their quiet abstention from taking part in the great affairs of the world are clearly reflected in this faithful mirror. The illustrations are of a high grade of photographic reproductions." Washington Post.

\section{V.-SWISS LIFE IN TOWN AND COUNTRY}

By ALFRED T. STORY, author of the "Building of the British Empire," etc.

"We do not know a single compact book on the same subject in which Swiss character in all its variety finds so sympathetic and yet thorough treatment; the reason of this being that the author has enjoyed privileges of unusual intimacy with all classes, which prevented his lumping the people as a whole without distinction of racial and cantonal feeling."-Nation.

"There is no phase of the lives of these sturdy republicans, whether social or political, which Mr. Story does not touch upon; and an abundance of illustrations drawn from unhackneyed subjects adds to the value of the book." -Chicago Dial.

\section{VI.-SPANISH LIFE IN TOWN AND COUNTRY}

\section{By L. Higgin.}

"Illuminating in all of its chapters. She writes in thorough sympathy, born of long and intimate acquaintance with Spanish people of to-day." -St. Paul Press.

"The author knows her subject thoroughly and has written a most admirable volume. She writes with genuine love for the Spaniards, and with a sympathetic knowledge of their character and their method of life."-Canada Methodist Revierw. 


\section{VII.-ITALIAN LIFE IN TOWN AND COUNTRY}

\section{By Luigi Villari.}

"A most interesting and instructive volume, which presents an intimate view of the social habits and manner of thought of the people of which it treats."-Buffalo Express.

"A book full of information, comprehensive and accurate. Its numerous attractive illustrations add to its interest and value. We are glad to welcome such an addition to an excellent series." Syracuse Herald.

\section{VIII.-DANISH LIFE IN TOWN AND COUNTRY}

By Jessie H. Brochner.

"Miss Brochner has written an interesting book on a fascinating subject, a book which should arouse an interest in Denmark in those who have not been there, and which can make those who know and are attracted by the country very homesick to return." Commercial Advertiser.

"She has sketched with loving art the simple, yet pure and elevated lives of her countrymen, and given the reader an excellent idea of the Danes from every point of view."-Chicago Tribune.

\section{IX.-AUSTRO-HUNGARIAN LIFE IN TOWN AND COUNTRY}

By Francis H. E. Palmer, author of "Russian Life in Town and Country," etc.

"No volume in this interesting series seems to us so notable or valuable as this on Austro-Hungarian life. Mr. Palmer's long residence in Europe and his intimate association with men of mark, especially in their home life, has given to him a richness of experience evident on every page of the book."-The Outlook.

"This book cannot be too warmly recommended to those who have not the leisure or the spirit to read voluminous tomes of this subject, yet we wish a clear general understanding of Austro-Hungarian life."-Hartford Times. 


\title{
X.-TURKISH LIFE IN TOWN AND COUNTRY
}

\author{
By L. M. J. Garnett.
}

"The general tone of the book is that of a careful study, the style is flowing, and the matter is presented in a bright, taking way." $-S t$. Poul Aress.

"To the average mind the Turk is a little better than a bloodthirsty individual with a plurality of wives and a paucity of virtues. To read this book is to be pleasantly disillusioned."-Public Opinion.

\section{XI.-BELGIAN LIFE IN TOWN AND COUNTRY}

\section{By Demetrius C. Boulger}

"Mr. Boulger has given a plain, straight-forward account of the several phases of Belgian Life, the government, the court, the manufacturing centers and enterprises, the literature and science, the army, education and religion, set forth informingly." - The Detroit Free Press.

"The book is one of real value conscientiously written, and well illustrated by good photographs."-The Outlook.

\section{XII.-SWEDASH LIFE IN TOWN AND COUNTRY}

By G. voN HEIDENSTAM.

" $\mathbf{A s}$ we read this interesting book we seem to be wandering through this land, visiting its homes and schools and churches, studying its government and farms and industries, and observing the dress and customs and amusements of its healthy and happy people. The book is delightfully written and beautifully illustrated."-Presbyterian Bannes.

"In this intimate account of the Swedish people is given a more instructive view of their political and social relations than it has been the good fortune of American readers heretofore to obtain." - Washington Even. Star. 
In Preparation :

\section{XIII.-ENGLISH LIFE IN TOWN AND COUNTRY}

Entertaining descriptions of English Society by one who knows Belgravia from experience and Whitechapel from keen observation. In order that personalities and real occurrences might be described without reserve, the identity of the author is for the present withheld. 








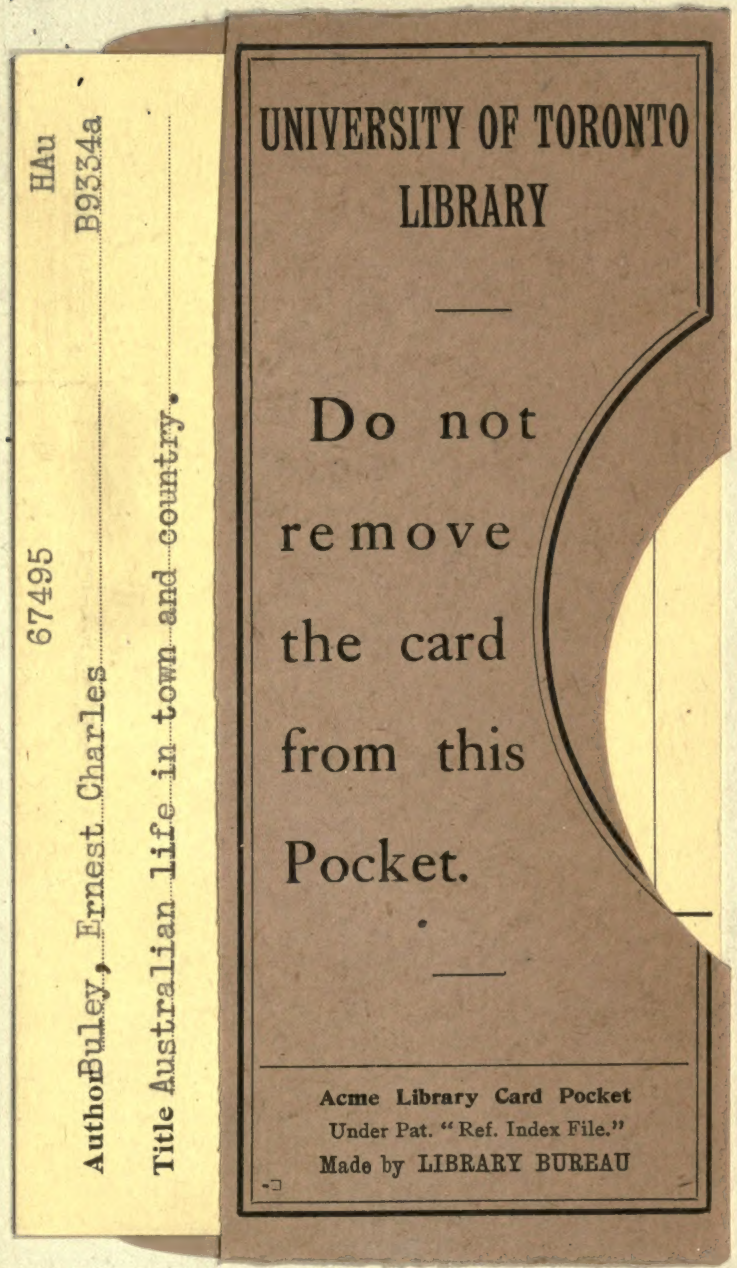


